

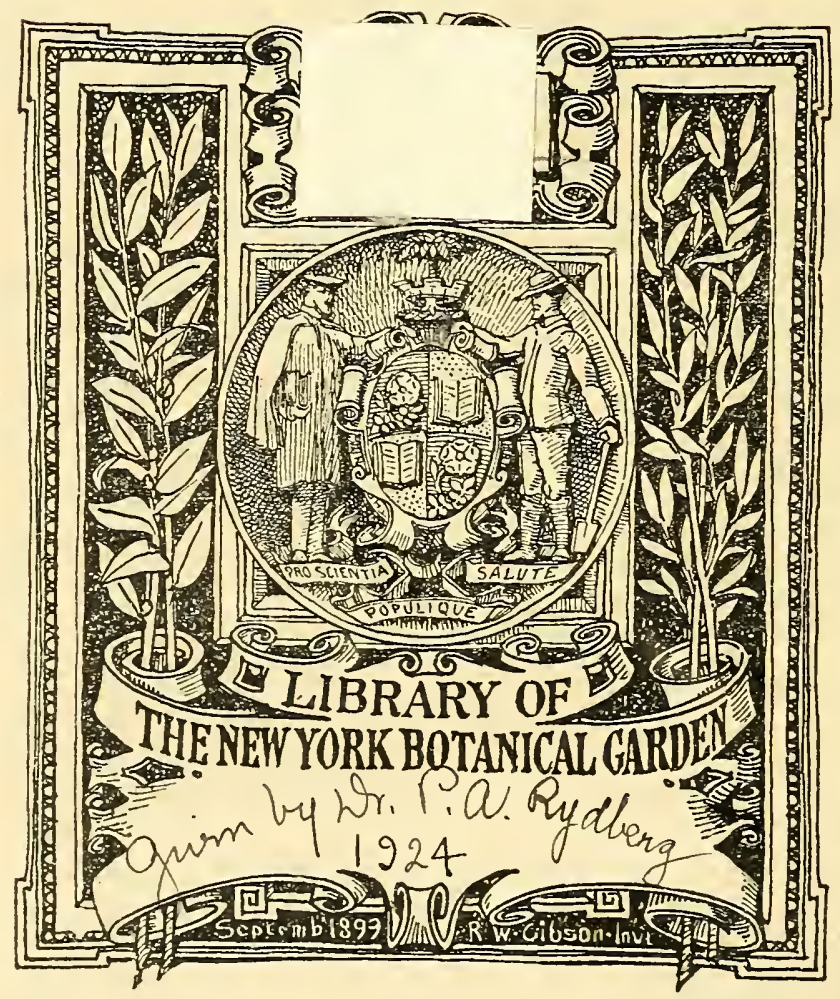





A REVISION OF THE NORTH AMERICAN SPECIES OF THE SECTION BORAPHILA ENGLER OF THE GENUS SAXIFRAGA (TOURN) L.

\section{A THESIS}

SUBMITTED TO THE FACULTY OF THE GRADUATE SCHOOL OF THE UNIVERSITY OF MINNESOTA

BY

ARTHUR MONRAD JOHNSON

IN PARTIAL FULFILLMENT OF THE REQUIREMENTS FOR THE DEGREE OF DOCTOR OF PHILOSOPHY JUNE 1919 

[Reprinted from Studies in the Brological Sciences, No. 4.]

A REVISION OF THE NORTH AMERICAN SPECIES OF THE SECTION BORAPHILA ENGLER OF THE GENUS SAXIFRAGA (TOURN) L.

A THESIS

SUBMITTED TO THE FACULTY OF THE GRADUATE SCHOOL OF THE UNIVERSITY OF MINNESOTA

BY $\quad \begin{array}{ccc}2 \\ y-20\end{array}$

ARTHUR MONRAD JOHNSON

IN PARTIAL FULFILLMENT OF THE REQUIREMENTS FOR THE DEGREE OF DOCTOR OF PHILOSOPHY

JUNE 1919 1923 (see thistran:) 
Q24136

. 53 


\title{
A REVISION OF THE NORTH AMERICAN SPECIES OF THE SECTION BORAPHILA ENGLER OF THE GENUS SAXIFRAGA (TOURN) L."
}

\author{
Arthur Monrad Johnson \\ (With Plates I-XIX)
}

The section Boraphila was established by ENGLER (4) in his Index Criticus Specierum atque Synonymorum Generis Saxifraga and was founded on those species of the genus Saxifraga (Tourn) L. which TAUSch (30) and later writers of the early part of the nineteenth century had grouped under the sections Arabisa (Arabidia Seringe), Micranthes, and Hydatica. In his later Monographie der Gattung Sagifraga ENGLER (5) retains the classification as first set forth in the Index, and except for the enlargement of the scope of the section the fundamental principles of this classification are adopted in the more recent treatment in ENGLER and PRANTL (6) Die Natürlichen Pflanzenfawilien.

In these studies the attempt will be made to show that the section Boraphila as ENGLER persisted in construing it is a heterogeneous one, consisting of species of widely different affinities, but which, however, can be realigned into natural groups on the basis of certain fundamental characters. ENGLER himself was not unconscious of a certain amount of heterogeneity in his section, however, for in his Monographie (p. 127) he makes this statement: "Allerdings weichen die Artengruppen, welche ich unter der section Boraphila zussammenfasse, mehr von einander ab, als die Artengruppen anderer Sectionen..." Nevertheless he grouped them all in the one section rather than make a number of new sections based on minor characters ("geringfügige Merkmale").

In the Monographie ENGLer separates the section Boraphila on the shape of the capsules and on their mode of dehiscence. But as far as these characters are concerned his section Robertsonia is scarcely to be distinguished from certain species of Boraphila (namely those of the section Arabisa). And again the "capsule" of Peltiphyllum is scarcely distinguishable from capsules of certain other species of Boraphila (for example, in Saxifraga oregana of the section Micranthes).

In Die Natïlichen Pflanzenfamilien ENGLER includes in the section Boraphila the genera Spatularia, Micranthes, Dermasea, and Aulaxis of HawOrth, Dermasea of Hoppe, and the sections Arabisa and Micranthes of TAUscr. No attention is given in the classification to the characters of the

IA thesis submitted to the faculty of the Graduate School of the University of Minnesote in partial fulfillment of the requirements for the degree of Doctor of Philosophy. 
carpels and the gland (or disc). The result is a more or less unnatural grouping based on minor characters. We thus find a collection of species of widely different affinities, as for example where Saxtifraga erosa Pursh (Saxifraga micranthidifolia Haw.) is grouped with Saxifraga Forbesii Vasey, and where Saxifraga hieracifolia. W. and K. is grouped with Saxifraga pennsylvanica L. and Saxifraga integrifolia Hook. (See sections Aulaxis, Micranthes, and Chionophila ${ }^{2}$ respectively, in this paper.)

Turning now to the early work of HAworTh (13) we find in that writer's Synopsis Plantarum Succulentarum the first attempt to break up the Linnaean genus Saxifraga, a task which he carried out more fully in his later Saxifragearum Enumeratio. In the latter work Haworth (14) made sixteen genera out of the old one, retaining the name Saxifraga for one of the genera. Without dwelling on the details of HAwORTH's work it may suffice to state that he pointed out, a century ago, the fundamental taxonomic distinctions between certain species which ENGLER many years later embodied in the section Boraphila. HAwORTH first clearly recognized the significance of epigyny and hypogyny in the classification of the species then known, and on these characters he based his generic distinctions. To illustrate, in establishing the new genus Aulaxis on the species Aulaxis (Saxifraga) micranthidifolia Haw. (Saxifraga erosa Pursh) HAworti clearly recognized the value of the characters of the carpels, as witness his description: "capsulae superae alte biparlitae basi solum coalitae, in restora acuta subdivaricato progredientes." The accuracy of his observation will be appreciated by referring to the figure of Aulaxis in Plate I. It is strange that these characters should have escaped the notice of subsequent investigators.

Of HAwORTu's other genera, including species with which we are here concerned, Micranthes was reduced to sectional rank by D. DoN (3), Tausci (30), and Seringe (26), and later by Torrey and Gray (31), and by Hooker (16). The genus Robertsonia was reduced to sectional rank by ENGLER (4). In a recent work of SMaLL (27) HaworTH's genera Micranthes and Spatularia are restored.

D. Don (3) grouped the species in two sections, Gymnopera and Micranthes, basing the distinctions on the characters of the calyx. Thus the calyx of the former section was described as "reflexed" that of the latter as "spreading." Along with these he included descriptions of the stamens and the carpels. Since the "reflexed" and the "spreading" conditions of the calyx are characteristic of hypogynous and epigynous species

\footnotetext{
Chronophrla sect. nov. Receptaculum ovario alte adnatum; folliculi elliptico-ovati plus minusve inflati superne conspicue contracti, stylis plus minusve elongatis saepe crassiusculis, stigmatibus globosis vel discoideis; glandula discoidea, margine inferiore calycis basi approximata; filamenta subulata plana ad aspicem incurva antheris oblongis; sepala patentia semina angusta ovata margine minime alata plus minusve striata.
} 
respectively (but are distinctly characters of minor importance) the classification automatically tended towards a natural arrangement, the significance of which Don seems not to have fully appreciated.

TAUsCH (30) grouped the species in three sections, Micranthes, Hydatica, and Arabisa. He, too, based his distinctions on the characters of the calyx. Thus the calyx of Micranthes was described as adhering to the ovary and reflexed ("calyx adhaerens, ore reflexo"), that of Hydatica and of Arabisa as free and reflexed ("caly'x liber, reflexus"). With the exception of the section Arabisa, where the species are well defined, TAusch's reliance on minor characters resulted in the grouping together of species of widely different affinities. The characters of the carpels were entirely overlooked.

SERINGE (26) followed the classification of TAUSCH, with its attendant confusion, in the relationships of the species. Neither SERINGE nor TAusch appreciated the importance of epigyny and hypogyny, and Haworth's accurate characterizations of the genera Robertsonia and Aulaxis seem to have been completely ignored by them. TORREY and Gray (31) adhered to the system of SERINGE, although they somewhat stressed the epigeous and hypogeous character of the caudex, a character which is subject to variation under different ecological conditions and unreliable as a character of major taxonomic consideration. Hooker (16) followed the same system in Flora Boreali Americana.

The system of classification proposed by TAUSCH and followed more or less closely by the subsequent writers above mentioned was considerably modified by Ledebour (18). He combined the sections Arabisa and Micranthes of TAuscr, giving the name Arabidia to the combination. Like his predecessors, however, LEDEBOUR based his classification wholly on characters of minor importance, which, together with the combination he introduced, added still more to the confusion in the classification.

This first attempt at combination thus initiated by LEDEBour reached its culmination in the work of ENGLER, who combined into a single group the sections that had been separated for nearly fifty years.

Rosendahl (25) considered the sections Micranthes, Arabidia, Spatularia, and in part Hydatica, as subsections of ENGLER's section Boraphila. He regarded the structure of the floral axis and of the carpels as the principal diagnostic characters of ENGLER's section.

Contemporaneously with RosennahL, SMALL (27) published a revision of the group, in which he digressed from the arrangement of previous writers by restoring the genera Micranthes and Spatularia of HAworTH, and at the same time adopting RAFINESQUE's (24) genus Heterisia for the monotypic Heterisia (Sarifraga) Mertensiana Bongard. SMall here recognized the hypogynous character of the species included in these two 
genera, but his arrangement of the genus Micranthes is less fortunate since it is made to include both epigynous and hypogynous species. In a later treatment of these species SMaLL (28) substitutes NECKER's earlier generic name Hydatica for the Spatularia of HAwORTH. In other respects the arrangement of the species described is essentially the same as that in North American Flora (l.c.).

\section{Discussion of the Proposed Classification}

The classification here proposed is founded on the characters of the hairs, the receptacle, the carpels, and the gland. ${ }^{3}$ All structures concerned are shown in Plates I, II, and III. While the present work materially increases the number of sections, the characters on which these are based are believed to be of sufficient taxonomic importance to justify the separations.

The hairs were first made use of in the classification by Godron (12), and while ENGLER (5, p. 75) based his primary distinctions on seed characters he offers a substitute classification, based on the characters of the hairs, for the larger categories.

Two types of hairs are to be found in the groups to be described, namely. the uniseriate type ("ein-reihig" or "articulati" of ENGLer) and the multiseriate ("mehrreihig" of ENGLER). The former type is composed of a single row, the latter of several rows of cells. The sections to be described thus fall into two divisions, the uniseriate-hair type represented by the sections Arabisa and Heterisia, the multiseriate-hair type represented by the remaining sections.

In some remarks on the use of hairs in classification ENGLER (5, p. 75) makes the following statement: "Da die Haare soweit meine Beobachtungen reichen, bei den Arten der einzelnen Sectionen stets gleichartig sind, so ist eine darauf gegründete Uebersicht jedenfals natürlich." However, neither in his Monographie nor later in Die Natürlichen Pflantzenfamilien did he adhere consistently to this statement inasmuch as he failed to recognize the characters of the hairs in those species which, in the scheme of classification here proposed, are included in the sections Arabisa Tausch, and Heterisia Rafinesque (the former being synonymous with the genus Spatularia of HAwORTH). Engler furthermore broke up the genus Robertsonia Haworth, setting apart in a new section, for which he retained the name, a group of species with multiseriate hairs, but at the same time inconsistently failing to separate the species of HAwORTH's genus Spatularia (Arabisa Tausch) on the same grounds.

"In this paper the disc or nectary is spoken of as the "gland."

- Heterisia (Raf.) sect. nov., Heterisia Raf. F1. Tell. 2:69. 1836; as genus. 
Previous writers have placed considerable emphasis on caulescence in their classifications, but since this character was found to vary considerably it is here regarded as of little taxonomic value. Within certain limited groups the petals and leaves are distinctive, and this is also true of the filaments and the inflorescences. The petals of the section Arabisa, for example, are distinctive of that section; so too are the leaves of the section Hydatica, although very similar leaves occur in the section Calthophyllum. ${ }^{5}$ The filaments and the inflorescence of Calthophyllum are unmistakable. Taken as a whole, however, these characters are only secondary in comparison with the carpels and glands. The same may be said of the calyx segments, which soon become strongly reflexed in the hypogynous species, but in the others the degree of reflexion may be greater or less, dependent upon the degree of adherence of the receptacle to the ovary. In the latter case they often become reflexed with the growth and expansion of the ovary, and are therefore not very reliable for taxonomic purposes. Seed characters are valuable criteria of relationship within certain groups, but appear to have received little attention. Unfortunately most collections are deficient in seed material. The distinctive character of the seeds is well shown in the section Arabisa. And in the difficult section Micranthes the seed characters sometimes proved to be the last resort in establishing affinities.

To turn now more particularly to a discussion of the classification proposed in this paper: as stated on a preceding page the sections are grouped into two major divisions on the characters of the hairs; the sections of the first division having "uniseriate," those of the second "multiseriate," hairs. Two lines of development are to be noted in the sections of the first division. On the one hand we have a series of three sections in which the ovary is wholly superior, namely Hydatica, Calthophyllum, and Aulaxis. In addition the carpels are more or less united, two lines of evolution being indicated, one in which the carpels are more or less bottle-shaped and erect, or spreading from the base at maturity, the other in which the upper free portions of the carpels are elongated and widely spreading-in $V$-shaped fashion-at maturity, while the lower capsular portion becomes somewhat constricted toward the base. The former condition is found in Hydatica and Calthophyllum, the latter in Aulaxis, in which also the gland surrounds the carpels as a thick girdle from the base to the middle. Marked differences in the glands serve to distinguish Hydatica and Calthophyllum. In Hydatica the gland lies close to the base of the carpels as a thick fleshy collar, and the

${ }^{3}$ Caltmoph ylu m, sect. nov. Ovarium librum; carpidia conica ad basin minime contracta $\mathrm{ct}$ coalita singula infra medio glandula dilatata cincta; folliculi elliptico-oblongi distincti inferne et superne maxime contracti, stylis brevihus attenuatis, stigmatibus parvis; filamenta primum clavata demum maxime elongata filiforria; sepala reflexa. 
follicles are erect at maturity and united either near the base or up to the middle. In Calthophyllum the carpels are entirely distinct and are spread apart as they increase in size, while the gland takes the form of a broad zone surrounding the basal portion of the carpels. There are also outstanding differences in the young carpels of these sections (Plate I).

On the other hand there is a series of sections in which the receptacle is more or less united with the ovary. This condition has been termed "subinferior." Four sections comprise this series, namely, Dermasea," Chionophila, Micranthes, and Tricarpum." The carpels are in all cases distinct to the base but are connected laterally by the adnate receptacle and at least the lower portion of the gland. The sections may be grouped into two divisions according to the number of carpels. Thus in Tricarpum the number is uniformly three, although four are sometimes found. In the remaining sections the number two is quite constant. The section Dermasea possesses a very distinctive gland which is in the form of a fleshy ring around the basal portion of the carpels in species having a very shallow receptacle. In Chionophila and Micranthes the glands are in the form of a broad fleshy and prominent disc, closely appressed to the base of the calyx in Chionophila, but considerably elevated in Micranthes. In Tricarpum the gland is very similar to that of Micranthes but is only slightly elevated. In both Micranthes and Tricarpum the margin of the gland persists as a conspicuous flange on the sides of the carpels. The species are readily referred to their respective sections on the characters of the gland. There is considerable variation in the depth of the receptacle in Dermasea, where in exceptional cases (Saxifraga nivalis) it is united to the carpels for about half their length. This variation occurs in certain species of the section Micranthes, as for example Saxifraga pennsylianica and $S$. oregana, in which this condition often gives the appearance of distinct hypogyny. The receptacle in Chionophila, Micranthes, and Tricarpum is characteristically deep.

The second division comprises only two sections, Arabisa and Heterisia. In both, the ovary is wholly superior and the carpels united about to the middle. The carpels and glands indicate two distinct lines of evolution. In Arabisa the young carpels are erect and broadly conical, terminating above in mere peglike beaks, while the gland has the form of a narrow girdle immediately above the base of the carpels. In Heterisia the carpels are strongly contracted above into slender, strongly divergent beaks, and are surrounded for the greater part of their length by a thick fleshy gland.

- Dermasea (Haw.) sect. nov., Dermasea Haw., Saxif. Enum. 45. 1821, as genus.

Tricarpum sect. nov., receptaculum ovario alte adnatum: carpidia tria distincta, receptaculo et supra glandula conjuncta; folliculi crassi inflati stylis crassis divergentibus rigidis, stigmatibus discoideis; elandula crassa $t x$ calycis basi breviter clavata, marcine inforinre persistente: filamenta subulata; sepala patentia. 
The differences between the mature follicles of these two sections are also pronounced (Plate II).

The criteria of classification described above are therefore regarded as fundamental, for the reason that they are fixed and quite obvious characters that clearly define the limits of the relationships.

\section{Key to the Sections}

1. Hairs uniseriate

A. Ovary wholly superior; carpels more or less united

a. Carpels elliptic or oblong at maturity

1. Gland a fleshy basal collar; follicles erect, united to the middle or mereiy at the base......................................... Hydatica

2. Gland a broad zone around the basal portion of the carpels; follicles dis-

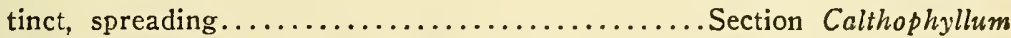

b. Carpels forming a V-shaped capsule at maturity; gland fleshy, surrounding the carpels to near the middle...................... Section Aulaxis

B. Ovary subinferior; carpels distinct, connected by the adnate receptacle

a. Carpels two

1. Gland a fleshy ring close to the base of the carpels and the calyx; receptacle shallow to deeper, flabellate.................... Section Dermasea

2. Gland a broad fleshy disc; receptacle deep

(a) Gland closely appressed to the base of the calyx.

(b) Gland considerably elevated, thick, convoluted, its margin persisting as a distinct flange........................ Section Micranthes

b. Carpels three, sometimes four; gland a broad fleshy disc slightly elevated above the base of the calyx, and its margin persisting as a flange.......... ........................................... Section Tricarpum

I1. Hairs multiseriate; ovary superior; carpels united to the middle

A. Gland a narrow girdle above the base of the carpels; carpels elliptic at matu-

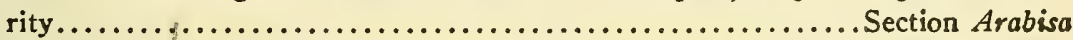

B. Gland a broad fleshy zone surrounding the ovary; carpels (capsule) pyriforin at maturity, strongly contracted above................. Section Heterisia

Section Hydatica Tausch, Hort. Canal. Fasc. 1. 1823.

Robertsonia Haw., Syn. P1. Succ. 321. 1812, as genus; in part.

Gymnopera D. Don, Trans. Linn. Soc. $13: 343$. 1822; in part.

Micranthes D. Don. l.c.

Arabidia, Seringe, DC. Prodr. $4: 40$. 1830; in part.

Boraphila Engler, Verh. Zool.-Bot. Ver., Wien. 19:522. 1869; in part.

Ovary wholly superior ; carpels conical, at length bottle-shaped, at maturity erect, stout to slender, united up to the middle or merely as high as the gland; beaks short and stout with thick stigmas, or elongated and somewhat recurved, with small stigmas; fruit a capsule; gland a fleshy collar surrounding the base of the carpels; filaments clavate; sepals reflexed (Plate I). 
Subsection I. Rotundifoliatae. Leaves orbicular or reniform-cordate, short and stout, except in one species where they are long and slender; crenate, long-petioled; carpels united beyond the gland; follicles erect, greenish or purplish; beaks stout or slender; stigmas globose or somewhat flattened.

Subsection II. Cuneifoliatae. Leaves cuneate at the base, tapering to short or elongate petiole-like bases, rounded and deeply incised-toothed at apex; carpels united merely at the base or to the height of the gland; capsules stout and thick, except in one species where they are elongated; beaks stigmas thick.

Like the section Arabisa this is one of the most interesting and most clearly defined of the series. While the characters of the leaves in the above described subsections are decidedly distinctive, other strong and unmistakable characters are to be found in the carpels, the gland, and the mature capsules. The very young carpels are conical but soon develop into stout bottle-shaped organs surrounded at the base by the fleshy, but not deep, gland.

Key to the Species or Section Hydatica

I. Leaves orbicular or reniform-cordate, crenate....... Subsection I. Rotundifoliatee A. Inflorescence open

a. Inflorescence elongate, paniculate-cymose.................. arguta

b. Inflorescence short, cymose, delicate.................... aestivalis

B. Inflorescence contracted or capitate..................... Nelsonizina

II. Leaves cuneate at the base, deeply incised-toothed at apex................... ..Subsection II. Cuneifoliatae

A. Inflorescence open, with slender branches, many-flowered..........S. Lyallii

B. Inflorescence few-flowered, the peduncles stout

a. Follicles elongate, contracted........................... davurica

b. Follicles stout, beaks short and thick.................... unalaschensis

The species of the Rotundifoliatae are most readily recognized by the characters of the inflorescence as described in the key, especially in the case of Saxifraga arguta. In S. aestivalis the inflorescence is very delicate. in which respect it differs most obviously from $S$. Nelsoniana. The same characters hold true in regard to the species of the Cuneifoliatae to distinguish $S$. Lyallii from the other members of the group, which do not differ to any extent in their inflorescences. S. davurica and S. unalaschensis can be distinguished from each other by the mature follicles, as characterized in the key.

The young carpels are very similar in the Rotundifoliatae, and those of S. aestiz'alis and S. Nelsoniana (Plate IV) are difficult to distinguish from each other except that those of the latter are larger and stouter, with considerably thicker beaks and stigmas. The gland of $S$. aestivalis is much 
thinner, and at first slightly elevated in the form of a projecting ring, while that of $S$. Nelsoniana is fleshier and crowds the bases of the stamens closely. Besides, the stigmas of the latter are somewhat flattened, while those of the former are large in proportion to the size of the carpels, and globose. Both species are stoloniferous, with a tendency to branch more in S. Nelsoniana.

The carpels of $S$. arguta (Plate IV) have elongated bodies and beaks, terminating in very small stigmas, and are united up to the middle. Fine lines run lengthwise along the sides. The species is much less stoloniferous than its allies.

The seeds of the Rotundifoliatae are distinctive in their markings in comparison with those of the Cuncifoliatae. The distinctions are shown in Plate IV. In this case the markings have the form of thin, septate, ribbonlike structures running along the surface and projecting conspicuously. In the Cuneifoliatac, on the other hand, the markings are plainly pectinate.

Three types of carpels occur in the Cuneifoliatae, which are made cleas in Plate IV. The stout, erect, purple carpels of $S$. unalaschensis are unmistakable. In $S$. davurica (Plate IV) they are elongated and not a little contracted, with much more slender and divergent beaks, and at the same time somewhat separated. In S. Lyalli (Plate IV) the beaks are greatly elongated and slender, and the stigmas oblong. The rich, dark-purple color of the carpels of $S$. unalaschensis is absent in these species.

The Rotundifoliatae are species of the high western mountain ranges. $S$. arguta is the most widely distributed and also the most abundant, occurring throughout the length of the Rocky Mountains and also southward into the Sierras. S. aestizalis occurs from the region of Yakutat Bay, Alaska, to Montana, and south into Oregon. S. Nelsoniana follows the coast of Alaska and thence inland along the Rocky Mountains to the Selkirks. Their ranges thus overlap for a considerable distance and, considered as a whole, constitute a notably continuous distributional belt, which, when coupled with the close structural similarities, further emphasizes the close relationships of the group.

The Cuneifoliatae do not show the same continuity of range, as far as can be determined. S. unalaschensis has been found on the islands of Bering Sea and in a few scattered localities on the west coast of Alaska to Unalaska. $S$. davurica is known to occur along the shores of Kotzebue Sound and Bering Strait, but has an extended Asiatic range as far as Lake Baikal and Dauria. The two species are very similar in vegetative characters. $S$. Lyallii appears to be an intermediate form; it has the elongate open inflorescence of $S$. arguta and its leaves are sometimes rounded distally but always cuneate at the base; besides, the carpels are greatly elongated and terminate in slender beaks. These similarities are further emphasized by 
the continuity of its range with that of $S$. arguta, and also of $S$. Nelsoniana, but only as far south as the Selkirks. In general it may be said to occupy the same relative position among the Cuneifoliatae as does $S$. arguta among the Rotundifoliatae.

Saxifraga aestivalis F. \& M., Ind. Sem. Hort. Petrop. 1 :37. 1835.

Micranthes aestivalis (F. \& M.) Small, N. Am. Fl. 22:2:147. 1905.

A low delicate plant with a thyrsoid inflorescence of delicate branches (Plate IV).

Distribution.-From the region of Yakutat Bay, Alaska, including the islands along the coast, to the Bitter Root Mountains of Idaho and western Montana, and to the region of Mt. Jefferson in Oregon.

Specimens examined:

ArAska: at base of Mt. Tabenkoff, June 22, 1892, F. Funston No. 40 (MBG $^{8}$ 84013; USNH 423509); summit of higin mountains, Yes Bay, August 30, 1895, Thos. Hozvell No. 1622; Kodiak, July 1, 1899, Wm. Trelease No. 4062.

Britrsn Columbia: Asulkan Valley, Glacier, July 26, 1910, F. K. Butters and E. W. D. Holway No. 584 (UMH) ; swampy places, Cowichan-Alberni Trail, Vancouver Island, June 26, 1906, C. O. Rosendahl No. 1602; stream side, Cameron River Valley, Vancouver Island, June 27, 1907, C. O. Rosendahl No. 1999 (UMH).

AleErTA: Lake Louise, Rocky Mountains, July 19, 1904, Edith M. Farr (MBG 84418); head of Lake Louise, July 30, 1904, Johr Macoun No. 65312 (USNH 529169).

Washington: Olympic Mountains, Clallam County, August, 1900. A. D. E. Elmer No. 2640 (USNH 401936, UMH) ; north fork of Bridge Creek, Okanogan County, September, 1897, 4. D. E. Elmer No. 716 (MBG 83922) ; Mt. Rainier, alt. 5,000 ft., September 1, 1913, F. K. Butters (UMH) ; borders of brooks, Goat Mountains, August 6, 1895, O. D. Allen No. 198 (UMH, MBG 84518, USNH 314093) ; Baldy Peak, Chehalis County, July 24, 1897, F. H. Lamb No. 1342 (MBG 84516); Mt. Rainier, 1906, Mrs. Carpenter No. 37 (MBG 84508) ; Paradise Park, Mt. Rainier, alt. 1,500-1,800 m. July 22-30, 1905, M.W. Lyon No. 116 (USNH 529458), as S. aestivalis by Engler and Irmscher; Mt. Rainier, August 15, 1888, C. V. Piper No. 2622 (UMH); Mt. Rainier, alt. 6,000 ft., August, 189, F. C. Smith (MBG 84510) ; Stevens Pass, alt. 4,000-6,000 ft., Sandberg and Leiberg (MBG 84124) ; Mt. Paddo, alt. about 2,000 m., July-October, 1896-1905, $W . N$. Suksdorf No. 2504 (MBG 84129, UMH).

OrEgon: at base of Mt. Jefferson, alt. about 6,000 ft., August 25, 1898, F. V. Cozille and I. Applegate No. 1176 (USNH 361993), as S. aestivalis by Engler and Irmscher.

Saxifraga arguta D. Don, Trans. Linn. Soc. $13: 356.1822$.

Saxifraga denudata Nutt., mss. (Unverified.)

Saxifraga punctata acutidentata Engler, Verh. Zool.-Bot. Ver., Wien. $19: 548.1869$.

Micranthes arguta (Don) Small, N. Am. Fl. $22: 2: 146.1905$ (Plate IV).

The abbrcviation MBG refers to the herbarium of the Missouri Botanical Garden and USNH refers to specimen sheets in the United States National Herbarium. In like manner UMH refers to the herbarium of the University of Minnesota. 
Distribution.-From William's Sound, Alaska, to New Mexico and Arizona, east central California, and extreme western Nevada.

Specimens examined:

Washington : along alpine rivulets, Olympic Mountains, August, 1895, C. V. Piper No. 2213 (UMH) ; wet banks, alt. 6,000 ft., Mt. Rainier, August, 1895, C. V. Piper (UMH) ; along rivulets, alt. 6,500 ft., Mt. Rainier, August, 1895, C. $V$. Piper No. 2025 (UMH) ; Olympic Mountains, Clallam County, August, 1900, A. D. E. Elmer No. 2639 (UMH, USNH 401962) ; Blue Mountains, July 29, 1897, Robert M. Horner (USNH 318696); Yakima region, 1882, R. E. Brandegee No. 304310 (MBG 84525); Mt. Rainier, alt. 6,500 ft., August 11, 1889, E. C. Smith (MBG 84511) ; Paradise Park, Mt. Rainier, July 17, 1907, H. C. Corvles No. 681 (MBG 745452); Stevens Pass, alt. 4,000-5,000 ft., August, 1893, Sandberg and Leiberg (UMH, MBG 84104); slopes of Mt. Stewart, alt. 4,000-5,000 ft., July 24, 1893, Sandberg and Leiberg No. 570 (MBG 84561).

IDAHO: marshy land along streams, alt. 7,000 ft., Silver City, Owyhee County, July 30, 1910, J. F. MacBride, No. 439 (USNH 542334, MBG 84592, UMH) ; sunny brook margins, alt. 5,000 ft., Custer County, July 31, 1910, J. F. MacBride No. 1463 (MBG 84567, UMH); stream banks, Trinity Lake region, Elmore County, alt. 8,000 ft., August 29, 1910, J. F. MacBride No. 673 (MBG 84591, UMH); head of Bear Creek, Bitter Root Forest Reserve, alt. 2,050 ft., August 26, 1897, J. B. Leiberg No. 2941 (USNH 306773); near Stevens Peak, alt. 1,600 m., August 4, 1895, J. B. Leiberg No. 1463 (MBG 84079, USNH 250912); wet soil by a stream, Victor, July 11, 1901, E. N. Wilcox and E. Merrill No. 1239 (USNH 581292); near Sawtooth, July 30-31, 1896, B. W. Evermann No. 668 (USNH 277512).

OrEgon: near Strawberry Butte, Blue Mountains, alt. 7,000 ft., July 13, 1896, F. V. Coville No. 567 (USNH 276169) ; granitic, wet soil, source Immaha, alt. 3,000 m., August 11, 1908, W. C. Cusick No. 3319 (MBG 84048); 1871, Elihu Hall No. 153 (MBG 84526) ; 1871, Elihu Hall No. 153 (MBG 84251).

Catifornia: Mt. Brocks, Farwell Gap, alt. 10,300 ft., April-September, 1897, C. A. Purpus No. 5252 (MBG 84515); along cold stream, three miles above Truckee, Nevada County, July 20,1903, A. A. Heller No. 7005 (USNH 467405); south side of Echo Lake in granite, moist places, El Dorado County, August 11, 1916, A. A. Heller No. 12547 (USNH 882627); Coyote Meadows, Tulare County, July 30, 1904, C. F. Baker No. 4311 (MBG 84069). Caulescent; looks different.

Montana: Stanton Lake, August 3, 1894, R. S. Williams No. 180 (USNH 288934) ; Spanish Creek, Gallatin County, July 1, 1901, J. Vogel (UMH) ; Red Lodge, July 24, 1S93, J. N. Rose No. 12 (MBG 84073); in brooks Mystic Lake, alt. 6,500 ft., July 11, 1905, J. W. Blankinship No. 182 (MBG 84115); upper temperate life zone, spruce belt, alt. 7,000 ft., Alta, July 26, 1909, Marcus E. Jones (MBG 84058) ; Spanish Basin, Madison Range, alt. 6,000 ft., July 11, 1896, J. H. Flodman No. 515 (MBG 84521) ; Belt Mountains, July 8, 1886, F. W. Anderson, No. 136 (UMH) ; Basin, July 5, 1892, F. D. Kelsey (UMH); Garnet, July 18, 1901, E. W. Scheurer (UMH).

Wyoming: Teton Mountains, alt. 10,000 ft., August 30, 1910, Merritt Cary No. 602 (USNH 858939); Electric Peak, Yellowstone National Park, alt. 8,400 ft., July 26, 1902, E. C. S. No. 156 (USNH 488736); Teton Pass, August 22, 1900, E. D. Merrill No. 359 (USNH 390769) ; Cold Springs, near Hot Springs, alt. 6,000 ft., 6,200 ft., July, 1893, F. H. Burglehaus (UMH) ; Bald Mountains, August 15, 1892, B. C. Buffum (UMH); on the banks of cold streams, Medicine Bow Mountains, Albany County, 
July 28, 1900, A. Nelson No. 7759 (UMH, MBG 84509); Union Pass, Wind River Mountains, August 11, 1894, A. Nelson, No. 843 (MBG 84520); June 28-August 1, 1899, L. H. Pammel (MBG 84514).

Utaн: Clayton Peak, Wasatch Mountains, alt. 9,500 ft., August 12-26, 1903, S. G. Stokes (MBG 84500); flora of Nebraska and Utah. Expedition of Capt. Jas. $H$. Simpson, 1858-59, Henry Engelmann (MBG 84187); slope of Aquarius Plateau, wet rocks, alt. 8,500 ft., July 29, 1875, L. F. Ward No. 453 (MBG 84507); Peterson Canon, Peterson, common on cold, moist banks, July 19, 1902, L. H. Pammel and R. E. Blackwood No. 3799 (MBG 84503); headwaters of Little Cottonwood Creek, above Alta, July 10, 1905, P. A. Rydberg No. 6849 (USNH 506353); headwaters of White Clay Creek, in moss attached to roots of trees close to the water. Expedition of Capt. Jas. H. Simpson, August 23, 1889, Henry Engelmann (MBG 84188); Mt. Ellen, Henry Mountains, alt. 11,000 ft., July 25, 1894, M. E. Jones No. 5678 (MBG 84051); Mt. Ellen, Henry Mountains, alt. 10,000 ft., July 25, 1894, M. E. Jones No. 5478 (MBG 84523).

Nevada: head of Fall Creek, Ormsby County, alt. 2,460 m., August 6, 1902, C. F. Baker No. 1434 (USNH 441006); Slide Mountain, Washoe County, alt. 7,500 ft., July 11, 1910, A. A. Heller No. 10207 (USNH 509144).

ArIzona: Thomas Peak, White Mountains, July 1-15, 1910, L. N. Gooding No. 626 (USNH 661595).

Colorado: Virginia Gulch, south slope of Needle Mountains, alt. 11,500 ft., July 14, 1901, Whitman Cross No. 32 (USNH 434312); Ruby, region of the Gunnison watershed, August 7, 1901, C. F. Baker No. 711 (UMH, USNH 412340); Hills, Larimer County, alt. 9,500 ft., July 7-19, 1905, C. F. Baker No. 3179 (UMH); upper La Plata Canyon, alt. 10,000 ft.; July 13, 1898, Baker, Earle, and Tracy (UMH, MBG 84517, MBG 84102) ; Cameron Pass, alt. 10,000 ft., July 29, 1896, C. F. Baker (MBG 84522) ; Dark Canon, alt. 2,800 m., August 6, 1901, F. E., and E. S. Clements No. 392 (MBG 84512, UMH) ; vicinity of Mount Carbon, along creeks, alt. 3,200 m., August 8, 1910, Ivar Tidestrom No. 3988 (USNH 751491) ; near Cameron Pass, August, 1892, G. E. Osterhout (UMH) ; Tolland, along stream, alt. 9,000 ft., June 29, 1913, L. O. Overholts No. 10064 (MBG 743695) ; upper Mt. Ricthophen. five miles west of Cameron Pass, alt. 9,000 ft., July 23, 1894, C. F. Baker, No. 3179 (UMH) ; Front Range, alt. 10,000 ft., July 6, 1896, C. S. Crandall (MBG 84524); from the headwaters of Cedar Creek, and the alpine ridges lying east of Middle Park, 1861, C. C. Parry No. 163 (MBG 84247 ) ; alpine and subalpine, lat. $39^{\circ}-41^{\circ}, 1862$, C. C. Parry (MBG 84248); Berthoud Pass, rich pine woods, alt. 8,500 ft., July 15, 1884, C. S. Sheldon (UMH); near Breckenridge, Mt. Guyot, and Mt. Baldy, alt. 9,700 ft., August 16, 1900, J. P. Anderson (MBG 718611) wet places, Arg. Pass, July 17, 1886, and Alpine Leadville, July 10, 1886, Wm. Trelease (MBG 84528) ; creek banks, Anita Peak. Routt County, August 3, 1903, L. N. Gooding No. 1756 (MBG 84092); Breckenridge, 1897, Mrs. Wislizenus (MBG 84573); Wheeler expedition of 1873, J. Wolf (MBG 84506); Farnham, July 10. 1891, "E. C. S." (MBG 84.504) ; banks of torrents below Berthoud Pass, alt. 11,000 ft., August 10, 1874, G. Engelmann (MBG 84250) ; Cañon City, Rocky Mountains, 1871, T. S. Brandegee No. 131 (MBG 84527) ; Graymont, alt. 11,000 ft., July 22, 1886, G.W. Letterman (MBG 777211); Breckenridge, 1887, S. D. Bereman No. 730 (MBG 84577); near Breckenridge, Summit County, alt. 9,700 ft., August 1901, Kenneth W. MacKenzie No. 205 (MBG 84513) ; Beaver Creek Camp, on Little Beaver, No. 1961, July 15, 1898, ex Herb. St. Agr. Col. (UMH) ; Boreas Pass to Como, Leadville, Forest 
(USNH 768658); Rocky Mountain alpine flora, lat. $39^{\circ}-41^{\circ}, 1862$, Hall and Harbour Park County, alt. 2,860-3,400 m., September 14, 1915, W. W. Eggleston No. 11968 No. 207 (MBG 8424).

New Mexico: Santa Fe Mountains, F. H. Snow (USNH 216133); along brook in aspen grove, vicinity of Ute Park, Colfax County, alt. 2,900 m., August 31, 1916, Paul C. Standley No. 14134 (USNH 896966); Mogollon Mountains, on or near the west fork of the Gila River, Socorro County, alt. 10,000 ft., O. B. Metcalfe No. 515 (USNH 495522, UMH, MBG 8450); Ponchuila Creek, Pecos River National Forest, alt. 8,600 ft., July 4, 1908, Paul C. Standley No. 4187 (USNH 498560) ; Pecos River, August 8, 1898, G. E. Coghill No. 157 (MBG 84505); Hermit Peak, August, 1883, F. H. Snow (MBG 776662); Rocky Mountains, 1864, C. C. Parry (MBG 84016).

Saxifraga davurica Willd., Sp. Pl. $2: 645.1799$.

Saxifraga punctata Pallas, Reise 3 :731. 1776.

Robertsonia davurica Haw., Saxifr. Enum. 56. 1821.

Micranthes davurica (Willd.) Small, N. Am. Fl. 22:2:143. 1905.

(Plate IV.)

Distribution.-Alaska, from Point Barrow or beyond to Kotzebue Sound and Bering Strait; in Siberia westward to Lake Baikal and Dauria.

Specimens examined:

Alaska: Camp 3, ten miles east of Cape Sabine, July 30, 1904, Chester Washburne (USNH 421207, without name, USNH 421208, USNH 421209-all under same date).

"Habitat in summis alpibus Davuriae sub nive," Willd. l.c.

"Crescit in montibus Sibiriae summis, nivalibus et in angulo maxime orientali Asiae," Pallas 20:47. The specimens enumerated above do not have the long petioles figured in Pallas' drawing (Tom. 3, Table P, p. 47, Fig. 2) although the petioles of specimen USNH 421207 are somewhat longer than those of the other two. No mature fruit is figured in Pallas' plate.

Saxifraga Lyallit Engler, Verh. Zool.-Bot. Ver., Wien. 19:542. 1869.

Saxifraga dahurica Lyall, in Herb. of the Royal Gardens, Kew. (Unverified. See Engler, Monogr. Saxifr. 141. 1872).

Saxifraga Lyallii Var. laxa Engler, Monogr. Saxifr. 142. 1872.

Micranthes Lyallii (Engler) Small, N. Am. Fl. 22:2:143. 1905.

A taller, more slender species than the other members of the Cuneifoliatae. The leaves are more rounded and flabellate, having broader teeth, and longer, narrower petioles. Five-carpelled flowers are not uncommon (Plate IV).

Distribution.-From the Malaspina Glacier and Yakutat Bay, Alaska, to Montana and Idaho.

The southern limits of the range of this species are rather indefinite. Small (27) gives the distribution as "Alaska and the Bering Sea region to Alberta, British Columbia, and Montana." ENGLER's (5) distribution reads : "Auf den rocky mountains unter $49^{\circ}$ n.B. um 2,000 m. Fort Colville 
(Lyall)." Lyall's Fort Colville specimen seems doubtful. PIPER (21) does not mention this species as occurring in northeastern Washington.

Specimens examined:

Alaska: Muir Glacier, Harriman Alaska expedition, July 11, 1899, Wm. Trelease, No. 4066 (MBG 83986) ; Muir Glacier, Harriman Alaska expedition, July 12, 1899, Wm. Trelease, No. 4067 (MBG 83985); Alpine Granite Creek, August 12, 1907, H. C. Cownles, No. 1365 (MBG 746118) ; Sindham Bay, July 28, 1905, Baker and Culbertson, No. 4952 (MBG 84096).

British Columbia: Prairie Hills, Selkirk Mountains, alt. 6,500 ft., July 19, 1904, C. H. Share, and T. B. Sryder, No. 402 (MBG 83913, UMH) ; alpine rivulet, Carbonate Draw, Selkirk Mountains, July 14, 1904, C. H. Shaw, No. 340 (UMH); alpine meadow in the Big Bend district, about $118^{\circ} 20^{\prime}$ W. long., $51^{\circ} 45^{\prime}$ N. lat., alt. $6,000 \mathrm{ft}$., July 22, 1905, C. H. Shaw, No. 941 (MBG 83914 and UMH); Eagle Mountain Glacier, August, 1902, C. O. Rosendahl, No. 998 (UMH) ; Streamsides, Prairie Hills, alt. 5,850 ft., Butters and Holway, No. 222 (UMH) ; Cougar Valley, Selkirk Mountains, August 10, 1913, Butters and Holway, No. 818 (UMH); Fish Creek Valley, August 10, 1906, Butters and Holway, No. a25 (UMH).

Alberta: Lake Louise, Rocky Mountains, July 19, 1904, Edith M. Farr, No. 30 (MBG 83912) ; Mt. Temple, Laggan, Alberta, alt. 7,000 ft., August 26, 1904, Butters, Holway, and Rosendahl (UMH) ; Laggan, ait. 6,500 ft., July 19, 1910, C. O. Rosendahl, No. 2489 (UMH) ; Mt. Temple, Laggan, Alberta, alt. 8,000 ft., September, 1906, Butters, Holway, and Rosendahl (UMH).

Montana: Lambert Valley, Mission Mountains, upper temperate life zone, alt. 7,000 ft., August 17, 1909, M. E. Jones (MBG 84060).

Saxifraga Nelsoniana D. Don, Trans. Linn. Soc. $13: 355.1822$.

Sarifraga punctata L. var. Nelsoniana (Don) Engler, Monogr. Saxifr. p. 39. 1872 .

Micranthes Nelsoniana (Don) Small, N. Am. Fl. 22:2:147. 1905.

A species of usually much stouter habit than S. aestivalis (Plate $I^{\top}$ ).

Distribution.-From Point Barrow along the coast of Alaska to Montana.

Specimens examined:

AlASKa: Cooper Island, September 3, 1891, as Saxifraga crassifolia, Jas. M. Macoun (MBG 83993, USNH 249366) ; Unalaska, July 25, 1891, Jas. M. Macoun, No. 45 (USNH 249364); St. Matthew Island, August 10, 1891, Jas. M. Macoun, No. 46 (USNH 249363); St. Paul Island, July 30, 1891, Jas. M. Macoun, No. 58 (MBG 84015) ; St. Matthew Island, August 19, 1891, Jas. M. Macoun No. 59 (MBG 83994).

The following collections were made by $W m$. Trelease on the Harriman Alaska expedition, 1899; Douglas Island, July 21, 1899, No. 4047 (MBG 84009); Aqua Dulce River, June 21, 1899, No. 4048 (MBG 84007); Port Wells, June 26, 1899, No. 4049 (MBG 84011) ; Ocra, June 24, 1899, No. 4050 (MBG 83995, 83996; St. Paul Island, July 9, 1899, No. 4051 (MBG 84003) ; St. Lawrence Island, July 13, 1899, No. 4052 (MBG 84008); Hall Island, July 14, 1899, No. 4053 (84001); Hall Island, July 14, 1899, No. 4054 (MBG 84997) ; Pt. Clarence, July 12, 1899, No. 4055 (MBG 84002); Pt. Clarence, July 12, 1899, No. 4056 (MBG 83998) ; St. Matthew Island, July 15, 1899, No. 4057 (MBG 84000) ; St. Matthew Island, July 14, 1899, No. 4058 (MBG 83999); Juneau, July 25, 1899, No. 4060, "Unusually stout and pubescent" (MBG 84010) ; Juneau, July 25, 1899, No. 4061 (MBG 84006). 
Kukak Bay, Harriman Alaska expedition, July 5, 1899, De Alton Saunders, No. 4065 (MBG 84005); Popoff Island, United States Coast Survey, Dall's exploration, 1871-72, M. W. Harrington (USNH 424500); Shumagin Island, 1871-72, $M . W$. Harrington (MBG 84014); Mucklung River, near Nushagak, July 25, 1882, . . . . No. 35 (USNH 423510) ; St. Paul Island, July 30, 1891, C. H. Merriam (USNH 424511); Kukak Bay, Harriman Alaska expedition, July 1 to 5, 1899, F. V. Coville and H. Kearney, Jr., No. 1663 (USNH 374093); Popoff Island, Shumagin Islands, July 8 to 19, 1899, Trevor Kincaid (USNH 375087); Hubbard Glacier, Disenchantment Bay, Harriman Alaska expedition, June 21, 1899, F. V. Coville and T. H. Kearney, No. 1081 (USNH 374091) ; Kukak Bay, Harriman Alaska expedition, July 1 to 5, 1899, F. V. Coville and T. H. Kearney, No. 1624 (USNH 374092); Unalaska, Harriman Alaska expedition July 8, 1899, F. $V$. Coville and T. H. Kearney, No. 1753 (USNH 374095); Halibut Cove, Cook Inlet, July 21, 1899, Harriman Alaska expedition, F. V. Coville and T. H. Kearncy, No. 2432 (USNH 374094); Sitka, Harriman Alaska expedition, July 14-17, 1899, F.V. Coville and T. H. Kearney, No. 867 (USNH $374090)$; Port Wills, Prince William Sound, Harriman Alaska expedition, June 26, 1899, F. V. Coville and T. H. Kearney, No. 1265 (USNH 374089); summit of high mountains, Yes Bay, August 3, 1895, Thos. Howell, No. 1622 (MBG 84012); springy slope, Bennett, July 31, 1907, H. C. Coweles, No. 002 (MBG 745046); Windham Bay, May 31, 1905, as $S$. Nelsoniana on label by Engler and Irmscher, J. D. Culbertson (Baker No. 4888), (USNH 666035, MBG 84098); St. Lawrence Island, mountain side, spongy tundras, Gambell, July 15, 1904, as S. Nelsoniana by Engler and Irmscher, E. P. Campbell (USNH 422067, USNH 422070); Herendeen Bay, July 12, 1890, The Albatross (USNH 423501); Herendeen Bay, July 12, 1890, The Albatross (USNH 423502); Kodiak, July 28, 1904, C. V. Piper, No. 4273 (USNH 420725); 1873, Dall (USNH 430725); Seal Island, 1875, Capt. Bryant (USNH 423508); St. George Island, Pribiloff Islands, July 21, 1895, F.W. True and $D$. W. Prentiss, Jr., No. 53 (USNH 231527) ; Camp Retreat, near Hotham Inlet, June 29, 1880, Lt. G. N. Storey (USNH 139475 ) ; 1878, L. M. Turner, No. 2092 (USNH 423503) ; Atka Island, common in rockỳ places, July 1, 1880, L. M. Turner, No. 1220 (USNH 139478); Glinka, Copper Island. Commander Islands, southwest of Bering Sea, August 7, 1895, Leonard Stejneger, No. 53 (USNH 242470) ; Wrangle Island, Arctic America, 1881, Dr. Ross (USNH 266832); Stepovak Bay, Harriman Alaska expedition, July 8 to 19, 1899, Chas. Palachr (USNH 375479) ; Tundra, Teller Reindeer Station, vicinity of Port Clarence, F. A. Walpole, No. 1464 (USNH 348570, 378564); Herald Island, 1881, Capt. Hooper (USNH 423507 ) ; St. Paul Island, Bering Sea, July 2, 1890, Wm. Palmer, No. 423 (USNH 327982) ; Cape Sabine, lat. $68^{\circ} 53^{\prime}$ N., long. $164^{\circ} 43^{\prime}$ W., August 12, 1894, James T. White (USNH 270187); Sitka, 1867, expedition to Alaska, U.S. Coast Survey (name illegible), No. 403 (USNH 423506).

British Columbia: Selkirk Range, August 20, 1885, J. Macoun (USNH 219580); north fork of Moose River, July 21, 1911, N. Hollister, No. 52 (USNH 622687, petals purple).

Saxifraga unalaschensis Sternb., Rev. Sax. Suppl. 2:9. 1831.

Saxifraga flabellifolia R. Br., mss., ex Torrey and Gray, Fl. N. Am. 1:569. 1838-40.

Saxifraga davurica var. unalaschensis (Sternb.) Engler, Monogr. Saxifr. 148. 1872.

Micranthes flabellifolia (R. Br.) Small, N. Am. Fl. 22:2:143. 1905. 
The very stout, deep purple follicles of this species are distinctive, differing markedly in this respect from the elongated, more slender follicles of $S$. davurica, besides, the blades of the leaves are more rounded toward the apex and longer petioled than in that species, but the dentation is similar (Plate IV).

Distribution.-Unalaska, Alaska Peninsula, Pribiloff Islands, Hall Island, St. Matthew Island, and probably along the Aleutian Islands.

Specimens examined:

ALASkA: Herendeen Bay, The Albatross, 1890, W. H. Hall's exploration, U.S. Coast Survey (USNH 423487); Herald Island, 1881, Capt. C. L. Hooper (USNFi 423486, 423485); Popoff Island, Shumagin Islands, July 8 to 19, Harriman Alaska expedition, Trevor Kincaid (USNH 375422); St. Paul Island, August 8, 1891, as "Saxifraga unalaskensis" C. Hart Merriam (USNH 423484); Cold Bay, July, 1904, C. V. Piper, No. 4276 (USNH 420728); Hall Island, Harriman Alaska expedition as S. davurica Pall., July 14, 1899, Wm. Trelease, No. 4070 (MBG 83965) ; St. Matthew Island, Harriman Alaska expedition, July 15, 1899, Wm. Trelease, No. 4072 (MBG 83966) ; Popoff Island, Harriman Alaska expedition, July 18, 1899, De Alton Saunders, No. 4069 (MBG 83968) ; St. Paul Island, August, 1891, Jas. M. Macoun (MBG 83969).

Section Calthophyllum, sect. nur.

Gymmopera D. Don, Monogr. Gen. Saxifr. in Trans. Linn. Soc. $13: 343$. 1822 ; in part.

Hydatica (Tausch) Seringe, DC. Prodr. 4:41. 1830; in part.

Micranthes (Haw.) Small, N. Am. Fl. 22:2:146. 1905, as genus; in part.

Boraphila (Engler) Rosendahl, Beibl. Bot. Jahrb. Nr. 83:71. 1905; in part.

Ovary free; carpels conical, slightly contracted and united at the base, each surrounded below the middle by a dilated gland; follicles ellipticoblong, strongly contracted above and below; styles short and slender; stigmas small; filaments at first clavate, then greatly elongated and filiform; sepals reflexed (Plates I, V).

Monotypic, including only the species described below.

The carpels of this section are at first conical but soon become characteristically bottle-shaped. They are united for a very short distance from the base. In the mature follicles the united portion is represented by the conspicuous constriction at the base. The receptacle is strongly contracted at maturity so that the follicles are spread apart considerably. The hypogyny is complete. The gland forms a broad girdle around each carpel, extending from the middle to within a short distance of the base. It is only slightly dilated and seems to disappear completely as the carpels develop.

The section combines certain features of Dermasea and Hydatica. It resembles Dermasea in the shape of the young carpels and to some extent 
in the gland, but differs from that section in being completely hypogynous and in having the carpels united at the base. In foliar characteristics it resembles Saxifraga arguta of the section Hydatica.

The most conspicuous features of the section are the showy inflorescence and the remarkably elongated and attenuated filaments which at maturity attain a length of over six millimeters.

Little is known about the distribution of the species representing the section. The specimens examined are all from Alaska, namely a few scattered localities in the lower basin of the Yukon. According to some writers it extends into British Columbia.

Saxifraga spicata D. Don, Trans. Linn. Soc. 13. 1822.

Saxifraga Geum Pursh, Fl. Am. Sept. 311. 1814.

Micranthes spicata (D. Don) Small. N. Am. Fl. $22: 2: 146.1905$.

The only mention of this species made by ENGLER (4) appears in the following words: "S. spicata Don....verosimiliter-punctata L." He makes no disposition of it in the sections (Plate V).

Distribution.-British Columbia to Alaska.

Specimens examined:

AlASKA: valley of Alatna River, near camp of July 20, about 15 miles above the mouth, July 20,1901,W.C. Mendenhall (USNH 377353); five miles below Fort Hamlim, Yukon Valley, 1902, Arthur J. Collier, No. 153 (USNH 379839); Cape Vancouver, 1891, British Bering Sea Commission collection, Jas. M. Macoun, No. 230 (USNH 249381) ; on the Yukon River, between Andreafski and Anvik, July 16-18, 1889, I. C. Russell (USNH 417561) ; Fort St. Michaels, Norton Sound, 1865-66, H. M. Bannister (USNH 423413).

The following annotations from the works of previous writers shed light on the distribution of the species:

"Alaska to British Columbia." Small, l.c.

"Sledge Island, N. W. Coast, Mr. Nelson, Behring's Straits, Menzies (v. sp. in herb. Banks)." Torrey and Gray, Fl. N. Am. 1:567. 1838-40.

Section Aulaxis, Haw., Saxifr. Enum. 47. 1821; as genus.

Robertsonia Haw., Syn. P1. Succ. 322. 1812, in part; as genus.

Hydatica Tausch, Hort. Canal. Fasc. 1. 1823; in part.

Micranthes Torrey and Gray, Fl. N. Am. 1:572. 1838-40; in part.

Boraphila Engler, “Index Criticus,” Verh. Zool.-Bot. Ver., Wien. 19:522. 1869.

Ovary superior; carpels erect, conical, united below the middle, the upper free portion becoming widely spreading at maturity. Gland, a thick fleshy girdle extending up over the carpels nearly to the middle, disappearing with age. Filaments clavate. Sepals reflexed. Seeds elongate, fusiform, 
marked with conspicuous longitudinal ridges, each surmounted by an undulating septate keel or edge. Hairs uniseriate. Fruit a capsule (Plates I, V).

Monotypic, including the species described below.

On a preceding page a reference was made to the distinctions on which Haworti founded the genus Aulaxis-namely on the ground that the capsules are divided almost into two. He also described the capsules as united only at the base "capsulae superae alte bipartitae basi solum coalitae." In this respect his description was accurate. He was mistaken, however, in describing the corolla as irregular "corolla irregularis." To these distinctions he added an accurate description of the seeds.

Haworth included in the genus a new species, Aulaxis (Saxifraga) muda which he had separated from Aulaxis (Saxifraga micranthidifolia), on the ground of its glabrous character, but he seems to have left no account of its origin. Seringe (26) embodied the species in the section Hydatica. preceding it with a question mark. In the account of an excursion to the mountains of North Carolina DR. GRAY (9) writes as follows concerning this species: "Aulaxis muda (Haworth, l.c., of unknown origin) appears to be the more ordinary and more glabrous form of this species" ( $S$. micranthidifolia Haw.). The species was not included by TORREY and GRAY (31) in the Flora of North America.

The carpels, the mature fruit, and the gland are very distinctive here. In addition the hypogyny is complete. At maturity the upper free portions of the carpels spread widely in a V-shaped fashion. No traces of the gland could be detected in the mature stage. The young carpels are quite sharply conical, the beaks soon elongating and terminating in small stigmas. The gland is at first fleshy and envelopes the carpels to the middle.

The distribution is limited to the Appalachian Mountains, from northern New Jersey to northeastern Georgia. The altitudinal range ascends to 2,000 feet or more.

Saxifraga micranthidifolia (Haw.) Britton, in Britton and Brown, Ill. Fl. 2:174, 1897.

Robertsonia micranthidifolia (Haw.), Syn. Pl. Succ. 322. 1812.

Aulaxis micranthifolia (Haw.), Saxifr. Enum. 47. 1821.

Saxifraga erosa Pursh, Fl. Am. Sept. 311. 1814.

Saxifraga micranthifolia Steud., Nom. Bot. 736. 1821.

Saxifraga Wolleana Torrey and Gray, Fl. N. Am. 1:569. 1840.

Micranthes micranthidifolia (Haw.), Small, Fl. S.E.U.S. 501. 1903.

The species has often been confused with $S$. penusylvanica which it somewhat resembles in vegetative characters, but the plants can be readily distinguished by the carpels. There does not appear to be any close affinity between the two (Plate V). 
Pursh's name, Saxifraga erosa, was for a long time applied to the species until Britron (1) restored Haworth's name. PURSH (23) based his distinctions wholly on inadequate vegetative characters. DR. Gray (31) referred Pursh's species to the section Micranthes Tausch, but later altered his opinion and referred it to the section Hydatica Tausch, though on what grounds is not quite clear. At the same time he was led also to modify his conclusions regarding Saxifraga Wolleana Torrey and Gray, which was referred by him to the section Hydatica.

Distribution.-In the Appalachians from northern New Jersey to northeastern Georgia.

Specimens examined:

North Carouna: cold streams and wet rocks, Biltmore, April 27, July 3, 1897, Biltmore Herbarium No. 885 (MBG 84083, UMH); cold streams, Biltmore, May 29. 1896, Biltmore Herbarium No. 885 (UMH, MBG 84318); Statesville, M. E. Hyams. (UMH) ; flora of Roan Mountains, alt. 6,000 ft., June 25, 1880, J. S. Chickering, Jr. (MBG 84316, UMH) ; Grandfather Mountain, Watauga County, June 16, 1891, Small and Heller, No. 246 (MBG 83939, UMH 1 and 2); mountains, S. B. Buckley (MBG 84321) ; wet places, flank of Roan Mountains, June 20, 1879, Redfield, No. 11722 (MBG 84314); mountains of North Carolina, Mitchell County, W.W. Ashe (MBG 84121).

TennesseE: along Wolf Creek near the mountains, July, 1896, A. Kuth (MBG 83985); banks of mountain stream, near Thunder Head Mountains, July, 1894, $A$. Ruth (UMH) ; banks of a mountain stream, Wolf Creek, July, 1898, A. Ruth, No. 265 (MBG 83938).

Pennsylvania: no locality, 1841, S. B. Mead (MBG 84217); Bethlehem, June 6, 1872, T. C. Porter (MBG 84216); Easton, Redfield herbarium, 1895, Traill Green (MBG 84317). 84313).

West Virginia: Pocahontas County, June 15, 1896, W. M. Pollock (MBG

No state cited: S. B. Buckley, no locality (MBG 84320).

Section Dermasea (Haw.). sect. nov.

Dermasea Haw., Saxifr. Enum. 45. 1821; as genus.

Micranthes D. Don. Trans. Linn. Soc. 13. 1822.

Boraphila Engler, Verh. Zool.-Bot. Ver., Wien. 19:522. 1869.

Ovary partly inferior; receptacle adnate merely to the base of the ovary or deeper; carpels bottle-shaped, free to the base, connected by the adnate receptacle and the gland; follicles erect or spreading at maturity; beaks short or elongated and slender, divergent; stigmas globose or sometimes oblong. Gland a fleshy ring or collar around the carpels a short distance above the base of the calyx. Filaments clavate or subulate. Sepals spreading or reflexed. Hairs uniseriate (Plates I, VI).

Haworth founded the genus Dermasea on Saxifraga (Dermasea Haw.) nivalis $\mathrm{L}$., and included two new species of questionable status. He regarded 
the spreading calyx segments, the "filiform" stamens, and the "semisuperior" ovary as the distinctive characters of the genus.

The uniformly bottle-shaped carpels and the peculiar swollen ring-like gland are the most distinctive characters of this section. The gland lies a short distance above the base of the carpels in those species in which the receptacle is very shallow; where the receptacle is deeper the gland lies a short distance above the base of the calyx. Among some western species the carpels and the glands are so strikingly alike that it is difficult to distinguish between them. But in such cases the type of inflorescence and the form of the filaments serve to throw the species into categories whereby their individual characteristics are projected and their identification thus facilitated. The most pronounced deviation from the type appears in Saxifraga caroliniana where the carpels and their beaks are very slender and elongated. A deviation from the typical form of the receptacle is found in $S$. nivalis where this structure is adnate to the carpels for about half their length. In general the differences in the depth of the receptacle are sufficiently pronounced to separate the species into two distinct natural groups, one possessing a shallow, the other a deep, receptacle. The species of the first category can be further separated on the characters of the inflorescence into two nearly equal groups, one with a cymose, the other with a paniculate, inflorescence. On comparison the species within each group will appear to be quite closely related, so much so that on foliar characteristics alone a number of them might easily be confused, as for instance $S$. aequidentata, S. Marshalli, and $S$. Allenii, or S. caroliniana, $S$. idahoensis, and $S$. microcarpa.

The smaller categories are based on the characters of the filaments, scapes, follicles, and petioles. Specific distinctions rest on the characters of the leaves, sepals, scape, and follicles, where these are of sufficient constancy and distinctiveness.

Turning to the category in which the receptacle is deeper and also broader, the division is made on the basis of the characters of the filaments -one with subulate, the other with clavate, filaments. The species of the first category here also show close affinity; for example: $S$. virginiensis and $S$. nivalis, which have been frequently confused. The two remaining species, which comprise the clavate division, are readily distinguished by the differences in size of the scapes and by the characters of the leaves.

Geographically the species are confined largely to the United States. Saxifraga nivalis, S. virginiensis, S. tennesseensis, S. Careyana, and S. caroliniana are species of the eastern United States. The two first named are not clearly delimited as to their ranges. S. nivalis is circumpolar, being a plant particularly of the Arctic regions. It is doubtful whether this species actually occurs in the United States. No American specimens of it have 
been available for study. The range of $S$. virginiensis is discussed more at length in connection with that species. S. Careyana and S. caroliniana are restricted to a small area in the southern Appalachians, from Tennessee to Georgia, while $S$. tennesseensis is found only in a small locality in the vicinity of Knoxville, Tennessee.

Among the western species the most widely distributed is S. saximontana, which follows the Rocky Mountains from British Columbia to the Yellowstone Park, with outposts in the Black Hills of South Dakota and in the Wallowa Mountains of eastern Oregon. The remaining species are known only by the type specimen or by scanty specimens from scattering localities, on which no definite statements as to their distribution can be based.

It is of interest to note that the western species may all be conveniently inscribed within a triangle having its apex in the Black Hills and its base coincident with a line drawn from north of Vancouver Island to the northeast corner of California. The great bulk of the species will be included within the lower (western) half of this triangle. When we add to this population the species of other sections that are also natives of this region we shall have, undoubtedly, one of the great distribution centers of the genus Saxifraga.

\section{Key to THE SPECIES}

I. Receptacle shallow, contracted

A. Inflorescence cymose

1. Filaments subulate

a. Scapes glabrous, at least above

(1) Leaves rusty-tomentose beneath.................... r. rufidula

(2) Leaves glabrous, shallowly dentate towards apex.......... S. laevicaulis

b. Scapes pubescent, leaves crenate-dentate................. aequidentata

2. Filaments clavate

a. Leaves deeply and finely crenate; inflorescence branches filiform...........

S. Marshallii

b. Leaves shallowly crenate, inflorescence stout

B. Inflorescence paniculate.

S. Allenii

1. Filaments subulate

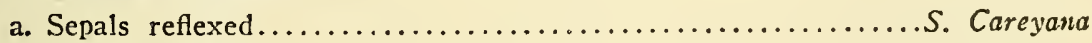

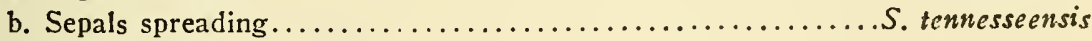

2. Filaments clavate

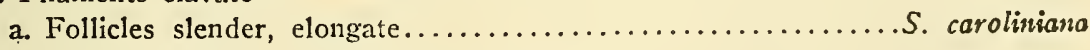

b. Follicles stout

(1) Petioles much exceeding the b!ades

(a) Leaves cuneate at the base....................... idahoensis

(b) Leaves truncate or subcordate at the base............... petiolata

(2) Petioles equalling or shorter than the blades

(a) Leaves sinuate or repand.......................... Hallii

(b) Leaves crenate-dentate toward the apex.............. microcarpa 
II. Receptacle deeper and broader

A. Filaments subulate; sepals spreading

1. Receptacle adnate to the basal portion of the carpels

a. Young carpels distinctly bottle-shaped; gland reduced....S. klickitatensis

b. Young carpels conical above the receptacle; mature carpels pyramidal above the fleshy gland........................... virginiensis

2. Receptacle deep, adnate to the lower half of the carpels, or nearly so....... ................................................... nivalis ${ }^{9}$

B. Filaments clavate; sepals spreading

1. Scaries tall; leaves serrate to sinuate-dentate.............. saximontane

2. Scapes much reduced; leaves crenate, rusty-tomentose beneath.

.S. occidentalis

Saxifraga Allenit (Small), n. comb.

Micranthes Allenii Small, N. Am. Fl. $22: 2: 144.1905$.

From all appearances a good species, but the specimens are in the early flowering stage so that the characteristics of the mature fruit and seeds can not be determined and compared with those specimens referred to $S$. saximontana (q.v.), and which have been confused with it. The relatively large flowers, rather compact cymules, crenately toothed and lanuginous leaves are distinctive. In two of the plants on the sheet the inflorescences are conspicuously thyrsoid (Plate VII).

Distribution.-Washington.

Specimens examined:

BRITISH Columbia : alpine rivulet, small peak above timber line, about $118^{\circ} 20^{\prime} \mathrm{W}$. long., $51^{\circ} 45^{\prime}$ N. lat., alt. 7,500 ft., July 25, 1905, C. H. Shaw, No. 1001 (UMH) ; Carbonate Draw, Selkirk Mountains, alt. 6,000 ft., July 13, 1904, C. H. Shaw, No. 302 (MBG 84110); gorge of Carbonate Draw, alt. 6,500 ft., July 13, 1904, C. H. Shaw, No. 257 (MBG 84089).

Washington: near Whistler Pass, east fork of Pasayton River, Okanogan Forest, Okanogan County, alt. 2,340 m., August 4, 1916, Eggleston, No. 13416 (USNH 886307) ; Goat Mountains, alt. 5,500 ft., O. D. Allen, No. 242 (MBG 84432). Typel

Saxifraga Careyana A. Gray, London Journ. Bot. 2:116. 1843.

Micranthes Careyana (Gray) Small, Fl. S.E.U.S. 501. 1903.

Two specimens from the herbarium of the Missouri Botanical Garden, No. 84203, bearing the legend "Saxifraga Careyana Gr. Coll. A. Gray, C. S. Sargent, I. H. Redfield, and Wm. M. Canby, Roan Mt., June 23. Journey to North Carolina, 1879" (merely a poor scape in fruit), and No. 84286, with the legend "Saxifraga Careyana, Gray! Grandfather Mt., N.C. Collected by Dr. Gray" afford the only authentic material at hand. The latter consists, however, of the bases of two separate plants with leaves and a single detached scape in poor condition. While the scape and inflorescence appear characteristic of $S$. Carcjanna, the leaves, on the other hand, are

- The detailed treatment of this species is deferred for a future paper. 
considerably coarser and thicker than in the other specimens cited above, and more suggestive of $S$. caroliniana. Two other specimens from the same herbarium, namely MBG 84204, "legit S. B. Buckley 1842," from North Carolina, and MBG 84287, "legit S. B. Buckley, . . . in montibus Carolinae et Georgiae," are referred by the collector to this species, but they are in too poor condition for use. The species was recognized by RosendaHL (25, p. 66) and by ENGLER (5, p. 136) who, however, also referred Saxifragc caroliniuna Torrey and Gray to this species, as a variety.

Saxifraga Careyana appears to be a much smaller and more delicate plant than either $S$. caroliniana or $S$. tennesseensis. The scape is very slender and also low, and the branches of the inflorescence filiform. HARsCHBERGER $(15$, p. 496$)$, depicting the vegetation of the southern Appalachians, found the plant growing under overhanging cliffs, and describes it thus: "the delicate little Saxifraga Careyana."

It is difficult to determine from the material whether the calyx-segments are consistently spreading or reflexed. In the flowers they appear spreading, although in some cases apparently reflexed. The same difficulty appears when in fruit, but here in most cases they are reflexed (Plate VII).

Distribution.- "Mountains of North Carolina" according to Small (27). The specimens examined that can with some degree of certainty be referred to this species, are all from Roan Mountain, North Carolina, as given below.

Specimens examined:

North Carouina: July 5, 1880, J. W. Chickering, Jr. (MBG 84284) ; alt. 6,000 ft., July $5,1880, J . W$. Chickering, Jr. (LMH) ; in shade of the overhanging rocks, June 21, 1879, J. H. Redfield, No. 11721 (MBG 84285).

Saxifraga Caroliniana A. Gray, Mem. Amer. Acad. 3:39. 1846.

Saxifraga Careyana var. caroliniana Torrey and Gray, Mem. Amer. Acad. 3:39; Engler, Monogr. Saxifr. 137. 1872.

Saxifraga Grayana Britton, Mem. Torr. Bot. Club 5:178. 1894.

Micranthes Grayana (Britton) Small, Fl. S.E.U.S. 501. 1903.

Micranthes caroliniana (A. Gray) Small, N. Am. Fl. 22:2:146. 1905.

A tall and graceful species with carpels and other floral characteristics very similar to those of $S$. Careyana, except that it has clavate filaments. The beaks of the carpels are characteristically long and slender. In foliar characters it is strikingly similar to the western Saxifraga idahoensis Piper. The following quotation from SMALL and VAIL (29), in regard to this species, may be of interest: "This interesting plant was first collected by DR. Asa Gray on Grandfather Mountain, North Carolina, growing with $S$. Careyana, both plants being published under that name in Am. Journ. Sci. XIII, in 1842. DR. GRAY wrote that the difference between the two plants was not detected till they bloomed in Cambridge the following spring, 
when they displayed characters that remained constant in cultivation." From descriptions of its habitat it appears to be a calciphobe species.

DR. Gray's (10, p. 39) original account reads: "Living plants of this species were gathered by myself in the Allegheny Mountains of North Carolina, and probably of Virginia, also, in the autumn of 1843, along with those of $S$. Careyana, which this species so nearly resembles that the difference was not detected until both came into flower the ensuing spring." Dr. GRAY noted and distinguished the two species on the characters of their filaments (Plate VIII).

Distribution.-Mountains of Virginia and North Carolina.

Specimens examined:

WeSt Virginia: about Chatham Hill Gap, on Walker Mountain, Smyth County, alt. 3,000 ft., June 13, 1893, John K. Small (MBG 84288, 84292). (The above two collections are both labeled Saxifraga caroliniana). UMH, as S. Grayana!

North Carolina: Negro Mountain, June 27, 1879, Gray, Sargent, Redfield, No. 11791 (Redfield herbarium), (MBG 84291).

Saxifraga Hallii, sp. nov.

Ovarium parve inferiore, carpidia conica aliquam elongata erecta dorso plus minusve 1-costato superne in stylos gradatim contracta base constricta glandula crassa convolutaque cincta, stigmatibus globosis, filamentis clavatis ad maturitam evidente subulatis calyce conspicue longioribus, sepalis maxime reflexis oblongis vel ovato-oblongis $1.5-3 \mathrm{~mm}$. longis, dorso margineque sparse pubescente, petalis ellipticis vel ovato-ellipticis apice rotundatis base plus minusve contractis, folia basalia $7 \mathrm{~cm}$. longa ovata vel elliptico-ovato aliquam crassa inferne pallida glabra vel margine minime ciliata sinuatodentata in petiolum alatum cuneate contracta petiolo lamina longiore vel aequale, scapus erectus $40 \mathrm{~cm}$. altus sparse glandulo-pubescentis.

Ovary slightly inferior; carpels conical, somewhat elongate, erect, with a more or less evident dorsal rib, gradually contracted above into the styles, constricted at the base, and surrounded by a thick, convolute gland; stigmas globose; filaments clavate, at maturity evidently sublate, conspicuously longer than the calyx; sepals strongly reflexed, oblong or ovate-oblong, 1.5-3 mm. long, sparsely pubescent on back and margin; petals elliptic or ovate-elliptic, rounded at the apex, more or less contracted at the base: leaves basal, $7 \mathrm{~cm}$. long, ovate or ellintic-ovate, rather thick, pale beneath, glabrous or slightly ciliate on the margins, sinuate-dentate, cuneately contracted into a broadened petiole, the blade exceeding or equalling the petiole; scape erect, $40 \mathrm{~cm}$. high, sparsely glandular pubescent.

The leaves of this species are very similar to those of "Saxifraga integrifolia Hook.," but the floral structures are all typical of the section Dermasea. The bracts possess tufts of long hairs on the margins, or are 
eciliate by the falling of the hairs. The gland becomes elevated by the growth of the carpels and takes the form of a wrinkled girdle. The young carpels taper gradually and somewhat pyramidally upwards into the rather slender elongated beaks (Plate IX).

Specimens examined:

Elihu Hall 151, "Oregon” . . . “ann. 1871" (Type MBG 84380). Plantae oregonensis. Legend: "Saxifraga virginiensis Michx., a very tall form." MBG 84380. (On a sheet from the Redfield herbarium, bearing also two specimens of Saxifraga californica. The type specimen of this species is designatcd "a"-the leaf-hand specimen).

Saxifraga idahoensis Piper, Bull. Torr. Bot. Club $27: 394.1900$.

Micranthes saximontana (E. Nelson) Small, N. Am. Fl. 22:2:145. 1905.

The outstanding characteristics of this species are the very shallow receptacle and consequent slightly inferior ovary, and its habit. In foliar characters it is strongly suggestive of Saxifraga caroliniana. It is a graceful plant with an open and diffuse inflorescence, lacking the rigid characteristics of the plants referred to as $S$. saximontana, whose range is contiguous. In some respects it resembles $S$. Allenii.

Its limited range may probably be extended by further exploration, since topographic and climatic conditions similar to those of its locality extend over a wide region (Plate VIII).

Specimens examined:

IрAно: moist hillsides, island in Clearwater River, above Lewiston, May 2, 1892, Sandberg, MacDougal, and Heller, No. 93; Palouse country and about Lake Coeur d'Alene, May, 1892, J. H. Sandberg; moist hillsides, Lewiston, May, 1893, J. H. Sandberg.

Saxifraga klickitatensis sp. nov.

Receptaculum ovarii parte inferiore adnatum flabelliforme, carpidia conica superne conspicue contracta, base glandula dilatata cincta stylis attenuatis, folliculi purpurei stylis conspicue attenuatis divergentibus, stigmatibus parvis ; filamenta subulata, plana, superne contracta; sepala reflexa; petala elliptica 1-nervia; pilorum cellulae $2-3$ cylindricae in seriem unam dispositae; folia basalia ovata serrato- vel crenato-dentata infra lanuginoso-pubescentia.

Carpels bottle-shaped, surrounded at the base or slightly above by a dilated gland; follicles purple, inflated at maturity, contracted above into slender elongated, strongly spreading to somewhat recurving beaks. Filaments subulate, flat, tapering above to a sharp point. Sepals 1-1.5 mm., green, becoming reflexed; lateral nerves usually 2, wanting in smaller segments, reaching beyond the middle or coalescing with mid-nerve below apex. Petals white, 1.2-2.7 mm. elliptic to elliptic-oblong, 1-nerved. Hairs of 
2-3 cylindrical cells, their glands oblong to orbicular, of 2-4 superposed cells. Leaves ovate to oblong-ovate, $2-6 \mathrm{~cm}$., glabrous above, lanuginous beneath, shallowly serrate- to crenate-dentate, tapering to a narrow petiolelike base about equalling or longer than the blades; ciliolate. Scapes about $15 \mathrm{~cm}$. high, sparsely short glandular pubescent, branching above into a widely spreading corymbose inflorescence, the branches rigid and slender, arising from the axils of rather small glabrous, lanceolate bracts which are broadest below the middle, the upper greatly reduced. Perennial from a stout fibrous-rooted caudex which is sometimes branched.

Aspect of $S$. aequidentata, but differs from that species in having a deeper receptacle, bright purple, slender-beaked follicles, shallower toothed leaves, small petals, and orbicular rather than elongate-oblong glands on the hairs (Plate IX).

Distribution.-Known only from the type locality.

Specimens examined:

Washington: damp rocks, west Klickitat County, April 9, May, 1883, W. N. Suksdorf (USNH 45806); Type! Right-hand specimen designated "a." Originally identified as $S$. nivalis L. and referred to by Engler and Irmscher to $S$. aequidentato Small.

Saxifraga laevicaulis sp. nov.

Receptaculum ovarii basi adnatum, carpidia conica supra basin latissima, superne stylis attenuatis maxime contracta supra basin glandula dilatata cincta dorsale uno-costata; filamenta subulata; sepala patentia; parva petalis multo breviora; petala elliptico-oblonga, 2.5-3.7 mm.; folia basalia ovata repando- vel sinuato-dentata, petiolis brevibus; scapus glaberrimus gracilis purpureus ramis corymbosis paucifloribus.

Carpels bottle-shaped, broadest at the gland, strongly contracted above into slender beaks, stigmas subglobose. Gland an irregular lobed collar above the base of the carpels; filaments subulate, rather slender, sharppointed; anthers short and broad to elongate, yellowish. Sepals 1.3-1.7 mm. oblong to ovate, rounded at apex, mucronulate by the projecting mid-nerve, dull green, thin, slightly united at the base, lateral nerves 2 , reaching to middle or uniting with mid-nerve at apex. Petals 2.5-3.7 mm., much exceeding the sepals, obtuse to rounded at apex, oblong to elliptic or sometimes ovate, sometimes slightly notched; mid-nerve with 2-3 alternate branches arising at or below the middle, these variously branched and their branches more or less anastomosing. Receptacle very shallow, adnate merely to the base of the carpels. Leaves $1-4.5 \mathrm{~cm}$. long, typically ovate, the smaller sometimes elliptic, thin, green, glabrous, acute to obtuse, shallowly dentate or sinuately dentate or repand, especially towards the apex, contracted into slender petioles which mostly exceed the blades. Scapes 
8-14 cm. high, very slender to delicate, purplish, glabrous except for an occasional gland-tipped hair, solitary, erect or assurgent, corymbosely branched above or from the middle into a few-branched, few-Howered inflorescence, the branches or peduncles very slender to delicate, bearing 1-3 flowers; glabrous. Perennial from a short, slender, fibrous-rooted caudex.

A species of very slender to delicate habit, with glabrous scapes which are quite purplish in color. The inflorescence is also very delicate. In the specimens examined the carpels are all very broad at the gland, strongly contracted upwards to the beaks, and conspicuously bottle-shaped (Plate VI).

Distribution.--Known only from the type locality.

Spccimens examincel:

Oregon: Mit. Grayback, June 15, 1904, C. V. Piper, No. 5061 (UMH). Type!

Saxifraga aequmentata (Small) N. Comb.

Micranthes aequidentata Small. N. Am. Fl. 22:2:145. 1905.

Ovary slightly inferior, the receptacle very shallow and flattened. Follicles short to longer, stout, somewhat spreading, occasionally 3 together; beaks very short, spreading. Stigmas at length elongate, papillate, becoming strongly deflexed-curved. Young carpels erect, broadened at base, with short stout beaks. Gland a dilated collar-like ring at the very base of the carpels. Filaments subulate, 2-3.5 mm. ; anthers purple on the margins. Sepals broad, ovate, oblong-ovate to deltoid, varying considerably, $1.5-2.5 \mathrm{~mm}$., acute to obtuse, free to base or nearly so, pubescent on the back; lateral nerves 2 , of various lengths, often coalescing with midnerve at middle or below apex; spreading at first, later reflexed. Petals large, 3-4 mm., white, broadly ovate to elliptic-oblong or obovate, scarcely clawed at the base; branches of the midnerve 2 , simple or variously branched, sometimes coalescing with midnerve at or below apex. Hairs short, the glands elongate oblong to ovovoid, or globose, multicellular, the former consisting of a row of rounded cells. Seeds fusiform, with longitudinal ridges of low moniliform or scarcely tuberculate cells of "teeth." Leaves basal, short, $7 \mathrm{~cm}$. and less, ovate to elliptic, sometimes triangular-ovate or deltoid, rounded at apex, uniformly and rather finely crenate-dentate, copiously brownish pubescent to tomentose beneath, contracted into somewhat elongate, flattened, petiole-like bases, commonly longer than the blades; leaves usually crowded among the remains of the earlier leaves. Scapes erect or assurgent, $20 \mathrm{~cm}$. tall and less, single or several together, scantily glandular-pubescent, branching at the top into a widely spreading corymbose many-flowered inflorescence with open cymules and the branches arising from small linear-oblong or lanceolatc bracts, copiously pubescent on the back, the upper much reduced. Peremial from a short stout fibrous-rooted caudex. 
Distribution: "Washington," according to Small, l.c.

Specimens examined:

WAshington: on wet rocks, mountains near Lower Cascades. W. N. Suksdorf, No. 967, type, referred to Saxifraga nivalis L. Watson, in herb.; Skamania County, May 29, 1886, W. N. Suksdorf (UMH).

OREGon: Oregon City, April 1885, Thomas Hozvell (USNH 45801, and UMH), referred to Saxifraga reflexa Hook.

The filaments of the type collection of Micranthes aequidentata Small (Suksdorf No. 967) do not agree with SMaLL's description.

Saxifraga Marshalli Greene, Pitt. 1:159. 1887-89.

Micranthes Marshallii (Greene) Small, N. Am. Fl. 22:2:145. 1905.

Very similar to Saxifraga aequidentata (Small) Engl. and Irmsch, but differs in its smaller size and in having clavate filaments and reflexed sepals. Greene's specimen was from Hoopa Valley, California (Plate VII).

Distribution.-Oregon to California (Small, l.c.).

Specimens examined:

California: ridges and meadows near Marble Mountains, Siskiyou County, alt. 7,000 ft., June, 1901, H. P. Chandler, No. 1613 (UMH, MBG 83916).

Saxifraga microcarpa sp. nov.

Receptaculum ovarii base adnatum, carpidia 2 , nonnunquam 3 , parva supra basin glandula dilatata cincta conica et superne multo contracta; folliculi parvi medio dilatati stylis brevibus stigmatibus parvis; filamenta latissine clavata antheris luteis; sepala oblongo-ovata ciliolata base conspicue coalita reflexa; petala elliptico-oblonga vel ovata base maxime contracta; folia basalia ovata vel elliptica infra sparse pubescentia marginibus purpureis grande dentatis vel serrato-dentatis; scapi erecti superne paniculato-ramosi ramis patentibus adscendentibus rigidis floribus parvis paucis vel multis.

Receptacle adnate to the base of the ovary; carpels 2 , sometimes 3 , small, surrounded above the base by a dilated gland, conical, and strongly contracted above; follicles small, dilated at the middle; styles short; stigmas small; filaments very broadly clavate, anthers yellow; sepals oblong-ovate, ciliolate, conspicuously united at the base, reflexed; petals elliptic-oblong or ovate, strongly coritracted into a clawlike base; leaves basal, ovate or elliptic, sparsely pubescent beneath, margins, purplish, coarsely dentate or serratedentate; scapes erect, paniculately branched above, the branches spreading, ascending, rigid; flowers small, few to many; bracts linear-lanceolate, small, cilioate; leaves bluish-green and brownish pubescent beneath; perennial from a rather slender, fibrous-rooted caudex (Plate IX).

Distribution.-Known only from the type locality. 
Specimens examined:

Montana: Herbarium of the University of Montana, two sheets, for convenience designated "a" and "b." Sheet "a" type, determined by P. A. Rydberg as S. idahoensis; Missoula, M. F. Elrod, No. 98, determined as S. reflexa montana by J. W. Blankinship with the note: "Has leaves of S. reflexa Hook. and inflorescence of S. Nutkana Moc. Either an intergrade or a new species."

Saxifraga occidentalis Wats., Proc. Am. Acad. $23: 264.1888$.

Micranthes occidentalis (Wats.) Small, N. Am. Fl. $22: 2: 144.1905$.

Distribution.-The exact range of this species is not known at present. According to Small (l.c.) it is distributed from "Alberta to Montana," a delimitation which is quite at variance with that given by him in Bull. Torr. Bot. Club, $23: 362,1896$, which reads, "apparently confined to Vancouver island and the mainland in the immediate vicinity." No published explanation of the difference is known to the writer. DR. Watson's own account reads: "From the Rocky Mountains of British America (Drummond) to British Columbia and Vancouver Island (Lyall, Macoun). Oregon (Cusick, Henderson, Howell), and the northern Sierra Nevada (Chico, Mrs. J. Bidwell; Gray)." The Cusick specimen is very likely the one listed above. The type locality, according to Small (l.c.), is the "Rocky Mountains."

It is to be noted in this connection that SMaLL's description of this species in Bull. Torr. Bot. Club, 23:362 is conspicuously at variance with the description he has given in North American Flora, $22: 2: 145,1905$, particularly in respect to the leaves. It seems that the descriptions must have been based on two rather different plants.

$S$. occidentalis Wats. is a small species with finely crenate leaves, which are also commonly deep vinous red and more or less reddish tomentose beneath. The scapes are sometimes stout, with a few-flowered, cymose inflorescence, and stout carpels. It is easily mistaken for S. rufidula (Small), except for its clavate filaments and obviously deeper receptacle. Elmer's specimen (2646) has been erroneously referred to $S$. rufidula by ENGLER and IRMSCHER on their label on the herbarium sheet (Plate X).

Specimens examined:

Orecon: Powder River Mountains, as S. nivalis; W. C. Cusick (UMH).

Washington: Mt. Rainier, "On rock cliffs," alt. 7,000 ft., August, 1895, as $S$. rivalis, C. V. Piper, No. 2034 (UMH); Olympic Mountains, Clallam County, July, 1900, Elmer, No. 2646 (USNH 401969), as S. nivalis.

Saxifraga petiolata sp. nov.

Receptaculum ovarii base adnatum, carpidia 2, nonnunquam 3, supra basin glandula dilatata cincta dorso conspicue uni-costato, stylis attenuatis elongatis, stigmatibus parvis oblongis, filamenta clavata inferne angustata, antheris purpureis, sepala oblongo-ovata reflexa base conspicue coalita 2-2.5 mm., petala ovata vel elliptica obscure retusa ad basin maxime contracta 3-3.5 mm., semina ellipitico-ovata superne latissima et ad apicem tuberculata longitudinaliter sulcata, folia basalia longe petiolata ovata vel oblongo-ovata subcordata marginibus sinuato- vel crenato-dentatis, scapus altus erectus 
graciliusculus sparse glanduloso-pubescentis ramis paniculatis diffusis patentibus multifloribus bracteis linearibus vel lanceolatis; pilorum cellulae in seriem unam dispositae glandulis multicellularibus globosis vel oblongis saepe purpureis.

Receptacle adnate to the base of the ovary, carpels 2 , sometimes 3 , surrounded above the base by a dilated gland, and with a conspicuous dorsal rib; stigmas small, oblong; filaments clavate, narrow below; anthers purplish; sepals oblong-ovate, reflexed, conspicuously united at the base, 2-2.5 mm.; petals ovate or elliptic, obscurely retuse, greatly contracted at the base. 3-3.5 mm., seeds elliptic-ovate, broadest above and tuberculate towards the apex, longitudinally grooved; leaves basal, long petroled, ovate or oblongovate, subcordate, margins sinuate or crenate-dentate ; scape tall, erect, somewhat slender, sparsely glandular-pubescent, paniculately branched, the branches diffuse and spreading and many-flowered; bracts linear or lanceolate; hairs uniseriate, glands globose or oblong, multicellular, often purple.

Scapes single or several; perennial from a short, stout, simple, or branched caudex.

Prominent characteristics: strongly contracted receptacle, inflated follicles, greatly elongated petioles, subcordate leaves, costate carpels, and large globose glands of hairs. It is also a tall plant with an open diffuse inflorescence of rather few branches (Plate VII).

Distribution.-Known only from the type locality.

Specimens examined:

OrEgon: on wet banks, Woodville, May, 1889, Thomas Howell (UMH, MBG 83917). Type!

Saxifraga RUFidula (Small) n. comb.

Micranthes rufidula Small, N. Am. Fl., $22: 2: 140.1905$.

A small species very similar to $S$. occidentalis (q.v.). The shallow receptacle gives the appearance of a hypogynous condition. Follicles relatively large (Plate VI).

Distribution.-Appears to be limited to Vancouver Island, adjacent British Columbia, and the Olympic mountain region of Washington.

Specimens examined:

Britrs h Columbta: Mt. Finlayson, Vancouver Island, May 17, 1887 (type collection), J. Macoun; Mt. Arrowsmith, July 18. 1887, J. Macoun; Mt. Arrowsmith, Vancouver Island, alt. 3,000-5,000 ft., June 29, 1906, C. O. Rosendahl, No. 1631; slopes of Mt. Arrowsmith, Vancouver Island, alt. 3,000-5,000 it., June 28, 1907, C. O. Rosendahl, No. 2030.

Washington: on wet cliffs, Olympic Mountains, alt. 3,000-5,000 ft., August, 1895, C. V. Piper, No. 2212; Mt. Angeles, on the highest elevations, 1909, Webster; Mt. Baldy, alt. 4,000 ft., July 7, 1902, H. S. Conrad, No. 279. 
Saxifraga saximontana E. Nelson, Erythea 7:168. 1899. 1905.

Micranthes saximontana (E. Nelson) Small, N. Am. Fl. 22:2:145.

\section{(Plate X.)}

Distribution.-Rocky Mountains of British Columbia and Alberta to the Yellowstone National Park, with outposts in the Wallowa Mountains of eastern Oregon, and in the Black Hills of South Dakota.

Specimens examined:

Wyoming: under a cliff, Yancey's Yellowstone National Park, July 17, 1899, $A$. and E. Nelson, No. 5917 (type) (MBG 84383, USNH 365280, UMH); rich marly hills in Jackson's Hole, Snake Fork, expedition of Capt. W. F. Reynolds, U.S.A., 1859-60, alt. 6,000 ft., June 12, 1860, Dr. F. V. Hayden (MBG 8419, MBG 84140).

IDAно: granite ledges, Kootenai County, June, 1891, J. B. Leiberg, No. 82 (UMH) ; mountains, Kootenai County, July, 1889, J. H. Sandberg (UMH) ; mountains, Kootenai County, July, 1889, J. H. Sandberg (MBG 84278); Little North Fork Basin, alt. 1,000 m., September 4, 1895, J. B. Leiberg, No. 1640 (MBG 84600).

OrEGoN: Little Fork, Wallowa Mountains, July 12, 1897, E. P. Sheldon, No. 8536 (USNH 528321), referred to $S$. aequidentata by ENGLER and IRMSCHER.

Montana: Spanish Creek, Gallatin County, J. Vogel (USNH 416291), 1901, referred to S. Allenii (Small) Engl. and Irmsch. by Engler and Irmscher.

South Dakota: Black Hills, near Fort Meade, May 6, 1887, W. H. Forrwood, No. 121, referred to S. Allenii (Small) Engl. and Irmsch. by ENGLer and Irmscher (USNH 317662).

The following specimens from the United States National Herbarium are considerably stouter, but in other respects are similar to the above. They have a heavier and, in earlier stages, a more thyrsoid inflorescence, but otherwise show the variations in the margins of the leaves as the above. In floral characters they are identical.

AlBerTA: vicinity of Banff, alt. 5,3007,000 ft., July 7, August 4, 1899, W. S. McCalla, No. 2290 (USNH 368516), referred to S. Allenii (Small) Engl. and Irmsoh. by ENGLER and IRMSCHER.

Montana: foothills, Midvale, June 18, 1903, L. M. Umback, No. 100a, referred to S. Allenii (Small) Engl. and Irmsch. (USNH 541458); Duck Lake, June 23, 1901, Stuart Weller (USNH 411603), referred to S. Allenii (Small) Engl. and Irmsch. This form possesses crenately toothed leaves and a stout scape with rather compact cymules.

The following specimens from the Selkirks and the Canadian Rockies are also here referred to this species, with reservation.

Britrsh Columgia: Carbonate Draw, July 13, 1904, C. H. Shaw, No. 302, T. R. Snyder (MBG 84110, UMH). These two sheets show the obvious differences in habit assumed by this species. The Minnesota Herbarium specimens would be easily mistaken for $S$. rhomboidea.

Washington: near Whistler Pass, East Fork of Pasayton River, Okanogan Forest, Okanogan County, alt. 2,340 m., August 4, 1916, Eggleston, 13416 (USNH 886307). Cymules at first compact. Some of the leaves are brown-pubescent beneath. 
The following specimens from the Selkirks and the Canadian Rockies are similar to the Montana plants.

Alrerta: Laggan, Rocky Mountains, alt. 7,000 ft., F. K. Butters (UMH); Canadian Rockies, F. K. Butters, No. 262 (UMH) ; Canadian Rockies, F. K. Butters, No. 281 (UMH).

British Columbia: Cougar Valley, alt. 6,500 ft., on limestone ledges, F. K. Butters, No. 340 (UMH) ; Cougar Valley, 5,500 ft., F. K. Butters, No. 363 (UMH); Avalanche Crest, Selkirks, alt. 7,200 ft., F. K. Butters, No. 401 (UMH) ; Mt. Cheops, alt. 8,000 ft., July 18, 1908, Butters and Holway, No. 347 (UMH).

Nelson's type specimens of this species are much more slender and delicate plants than the others enumerated above, probably due to the peculiar conditions under which they were found growing, but the coincidence of geographical distribution and the close similarity in floral and vegetative characteristics leave little doubt that they are all S. saximontana E. Nelson. The isolated outposts in the Black Hills and in the Wallowa Mountains of Oregon seem rather remotely connected, but it is exceedingly difficult to detect any differences in the plants except in the minutest details. The cotype material of $S$. saximontana shows more orbicular petals, broader and ciliolate sepals, lanceolate rather than linear bracts, and more multicellular glands on the hairs in some cases, but the same variations are to be found in other specimens.

The specimens referred to Saxifraga Allenii (Small), Engl. and Irmsch. by ENGLER and IRMSCHER are erroneously determined inasmuch as the leaves of this particular species are distinctly crenately toothed and the inflorescence thyrsoid. When placed side by side the plants are obviously different.

Saxifraga tennesseensis Small, Bull. Torr. Bot. Club $23: 364.1896$.

Micranthes tennesseensis Small, F1. S.E.U.S., 501. 1903.

A plant of characteristically stout habit (Plate VII).

Distribution.-Along the Tennessee River in the vicinity of Knoxville, Tennessee.

Specimens examined :

Tennessee: Knoxville, May, 1898, Albert Ruth (MBG 84397, 84120); April to May, 1897, MBG 84398; April, 1896, MBG 84396; April, 1895, 34120; April, 1895, MBG 84128; April, 1894, MBG 84290, UMH; Knoxville, May 5, 1895, J. G. Smith (MBG $34348,84576)$.

North Carolina: moist rocks, slopes of Craggy Mountain, Buncombe County, May 18, 1898, Biltmore Herbarium, No. 5651a (MBG 84333).

Saxifraga virginiensis Michx., Fl. Bor. Am. 1 :269. 1803.

Saxifraga vernalis Willd., Hort. Berol. 43. 1805. (Unverified.)

Saxifraga virginica Nutt., Gen. 1 :285. 1818.

Saxifraga pilosa Banks; D. Don. Trans. Linn. Soc. $13: 386.1822$, as syn. (Unverified.) 
Dermasea pilosa Haw. Saxifr. Enum., 9. 1821. (Unverified.)

Dermasea elongata Haw., l.c. (Unverified.)

A polymorphic species. Several rather distinct forms have been found which differ considerably in carpel and seed characters, but the exact status of which can not be determined at this time. Examination of Michaux's type specimens is necessary. The range of this species is peculiar and there appears to be some marked differences between the northern and the southern forms. The Minnesota specimens are without flowers and fruit so that their nature can not be learned and must await further collecting. The specimens from Missouri show certain characters which may prove sufficiently distinct to warrant setting them apart as distinct species (Plate IX).

DR. Fernald (8) has described several forms of this species from Massachusetts and New York. He notes that several aberrant forms of $S$. virginiensis occur. In attempting to distinguish between $S$. nivalis and S. virginiensis, however, DR. FERNALD dwells on unimportant vegetative and floral characters, whereas the outstanding differences between these two species which are to be found in the carpels, gland, and receptacle, receive no notice.

Distribution.-New Brunswick and Quebec to northern Minnesota; in the South, westward to Missouri.

Specimens examined:

Minnesota: exposed rocks, Two Harbors, May, 1891, J. H. Sandberg (UMH); rocky slopes of Pelican Lake, August 30, 1909, C. O. Rosendahl (UMH); Flag Island, Lake of the Woods, August 10, 1894, MacMillan and Sheldon, No. 2836.

Ontario: Kingston, May 7, 1881, J. Fowler (MBG 84353) ; Kingston, Jones Falls, May 21, 1881, J. Fowler (MBG 84354); Kingston, May 30, 1901, J. Fowler (MBG 84568); Sparta, May 14, 1899, G. E. Fisher, J. Macoum (MBG 84347).

Michigan: Isle Royal at Tobin's Harbor, August, 1900,W. A. Wheeler ("716 and 722").

Оноо : rocks, Hinckley, June $1,1894, J . R$. Watson (UMH).

New YoRK: Ithaca, April 30, 1891, Herman Schrenk (MBG 84371); Sullivan County, 1873, Eggert (MBG 84263); East Greenwich, 1861, Dr. Asa Fitch, No. 2419 (UMH).

Pennsylvania: Rawlinsville, 1884, Eggert (MBG 84366); along Conestoga Creek, Lancaster County, Ápril 12, 1889, J. K. Small (UMH); Allegheny County, April 28, 1892, Adolph Koenig (UMH); Rawlinsville, ex herbarium, James Galen (UMH) ; Safe Harbor, Lancaster County, April, 1893, Heller and Halbach, No. 804 (UMH) ; Glen Rock, York County, May 30, 1895, N. N. Glotfelter, M.D. (MBG 84352) ; rocks, Robinson's Knoll, near Philadelphia, April 25, 1872, Redfield, No. 2021 (MBG 84357) ; Conestoga, May, 1887 (no collector cited), (MBG 84596); Swarthmore, 1891, J. M. Greenman, No. 62L (MBG 737966); Westmoreland County, April 16, 1878, B. E. Pierron, No. 73 (MBG 777399); Mt. Alto, 1900, Jos. Illick (MBG 84070); on the Conestoga, Lancaster County, April 24, 1893, Heller and Halbach, No. 804. (MBG 84378); rocky places, Milford, May 15, 1905, C. A. Mill (MBG 84374); banks of Conestoga Creek, May, 1894, A. F. Eby (MBG 84066); near Philadelphia, 1889, J. M. Greenman, No. 628 (MBG 738696) ; ex Bernhardi Herbarium, Philadelphia 
(MBG 84360); banks of the Conestoga, May 1, 1895, Chas. W. Eisenhour (MBG 84362); Philadelphia, Beynick (MBG 84355); Quakertown, May 12, 1907, Ethel Knight Ball (MBG 83940).

MaINE: rocky ground, Seal Harbor, Mt. Desert, June 27, 1890, Redfield herbarium 16492 (MBG 84356); exposed rocks, Orono, May 23, 1888, M. L. Fernald (UMH); Orono, May, 1893, F. P. Briggs (UMH).

NEW HAMPSHIRE: Hanover, May 5, 1883, C. H. Hitchcock (UMH).

MassachusetTs: Amherst, May, 1890 and May, 1889, E. L. Morris (UMH); South Warmingham, 1890 (MBG 84369); Stony Brook, May 15, 1897, J. M. Greenman, No. 629 (MBG 738779); West Roxbury, May 13, 1898, J. M. Greenman, No. 2950 (MBG 742616) ; Middlesex, Fels, April 19, 1898, J. M. Greenman, No. 569 (MBG 738766); Winchester, May 9, 1897, J. M. Greenman, No. 636 (MBG 738957); Nonquit, E. P. (MBG 84367); Nonquit, May 1, 1889, E. P. No. 849 (UMH); dry rocky banks, Lexington, Day and Fernald (MBG 84372); Arlington, May 3, 1891. E. W. Dewart (MBG 84370); Nonquit, May 7, 1889, Miss Croll (MBG 84368).

Connecticut: Storrs, March, 1907, W. W. Ohlweiler (MBG 792271); rocky woods, Southington, May 23, 1897, C. H. Bissell, Nos. 2\%2 and 813 (MBG 84364).

New Jersey: Woodbridge, May, 1893, Rev. L. H. Lighthipe (UMH) ; Peapack, April, R. C. Perry No. 50 (MBG 84562); Peapack, R. C. Perry (MBG 84564); rocky banks, Greenwood Lake, Passaic County, May 19, 1907, Kenneth MacKenzie, No. 2560 (MBG 84584).

Section Chionophila, sect. nov.

Micranthes, Haw., Syn. P1. Succ. 1812; in part.

Arabidia, Ledebour, Fl. Ross., 2. 1844 ; in part.

Boraphila, Engler, Verh. Zool.-Bot. Ver., Wien. 1869; in part.

Receptacle deeply adnate to the ovary; follicles elliptic-ovate, more or less inflated, conspicuously contracted above; styles more or less elongate, often stout; stigmas globose or discoid; gland discoid; the lower margin closely approximated to the base of the calyx; filaments subulate, incurved toward the apex; anthers oblong; sepals spreading; seeds narrowly ovate, slightly winged on the margin, and more or less striate.

The most conspicuous characters of this section are the deep campanulate receptacle and the discoid gland which lies close to the base of the calyx. The receptacle attains the greatest depth in Saxifraga rhomboidea, enclosing the carpels for half their length. It is shallowest in S. franciscana. As development proceeds the gland assumes a verrucose appearance and surrounds the carpels as a broad zone immediately above the base of the calyx. As a rule the beaks are stout, except in S. franciscana where they are quite slender and also strongly bent at right angles or even recurved (Plates II, III, XI).

The section embraces only three species, which, in their distribution, are plants of high altitudes and of far northern latitudes. S. hieracifolia is circumpolar in range, having its type locality in the Carpathian Mountains of Hungary. The specimens examined are from scattering stations 
on the west coast of Alaska, from Point Barrow southward, including the islands of Bering Sea. S. rhomboidea inhabits the higher elevations of the Rocky Mountains, from southeastern British Columbia to central New Mexico. Specimens of it have also been examined from a few scattering stations in the Cascade Mountains of Washington and Oregon and the Sierras of California. S. franciscana is restricted to the San Francisco Mountains of Arizona. It somewhat resembles reduced forms of $S$. rhomboidea of which it is probably an offshoot.

The few species represented in the section can be readily separated into two categories on characters of the inflorescence, and also on the color of the petals. Thus we obtain one group with a capitate inflorescence and white petals, which includes $S$. rhomboidea and $S$. franciscana, two rather closely related species. The second group is represented by the single species $S$. hieracifolia which possesses a spicate inflorescence and purple petals. The two first named species are separated on the characters of the carpels and the beaks. The differences in the inflorescences are quite obvious, although in reduced forms of $S$. hieracifolia where only a few flowers are present the inflorescence is capitate.

\section{Key to THE SPECIES}

I. Inflorescence capitate; petals white

1. Follicles stout; beaks erect or spreading............... rhomboidea

2. Follicles small; beaks slender, strongly divergent........... franciscane

II. Inflorescence spicate, occasionally capitate; petals purple........... hieracifolie

Saxifraga rhomboidea Greene, Pittl. 3:353. 1896-1898.

Saxifraga interrupta Greene, Plantae Bakerianae. (Unverified.)

Saxifraga rhomboidea austrina A. Nelson, Bot. Gaz. $31: 394.1901$.

Micranthes rhomboidea (Greene) Small, N. Am. Fl. 22:2:136. 1905.

Saxifraga nivalis Hook., Fl. Bor. Am. 1:248. 1832; in part; not $S$. nivalis $\mathrm{L}$.

Specimens of this species have been frequently referred to Saxifraga nivalis L., from which it differs, however, both in general appearance and in floral characters. The inflorescence of $S$. nivalis is distinctly corymbose rather than capitate, the leaves are broadly ovate rather than oblong-ovate, and the gland is a thick, fleshy, lobed ring raised above the base of the calyx. S. nivalis is also typically a much smaller plant than $S$. rhomboidea (Plates X, XI). Differences in the glands of the hairs will also be noted on comparing the plates referred to.

Distribution.-Rocky Mountains from British Columbia and Alberta to New Mexico, and in the Cascade Mountains, and the Sierra Nevada.

Specimens examined:

ALASKA: Shumagin Island, 1871-72, M. W. Harrington, U.S. Coast Survey. W. H. Dall's exploration (MBG 84020). 
Washington: Cascade Mountains, Yakima region, June, 1882, ex herbarium, Redfield, No. 14158.

IDAHO: ridges south from Wiesner's Peak, alt. $2,050 \mathrm{ft.}$., July 27, 1895, J. B. Leiberg, No. 1390 (MBG 84077).

California: Sierra County, 1874, J. G. Lemmon, No. 74. Sheet bears a specimen labeled $S$. nivalis L. from Disco, Greenland, lat. $70^{\circ}$, legit $D r$. Parry, ex herbarium Dr. A. Gray, Redfield herbarium, No. 13683.

Montana: wet meadows, Flathead Pass, alt. 7,400 ft., June 29, 1905, J. W. Blankinship, No. 183 (MBG 84114); May 30, 1892, Dr. J. D. Heald (MBG 84373).

Wroming: Bald Mountain, Angust 15, 1892, B. C. Buffum (UMH); near Mammoth Hot Springs, alt. 7,000 ft., June, 1893, E. H. Burglehaus (UMH, two sheets); on Madison River, alt. 5,500 ft., June 26, 1860, Dr. F. V. Hayden (MBG 84134); Pole Creek Hills, June 2, 1894, Aven Nelson, No. 128, as "Senecio lugens foliosus Gray."Evidently a mistake in labels (UMH); Hone Creek, June 6, 1893, Aven Nelson (UMH); Saw Mill Creeks, May 25, 1895, Aven Nelson, No. 1239 (MBG 84429, UMH) ; Table Mountain, June 2, 1894, Aven Nelson, No. 127 (MBG 84430), as Saxifraga nivalis L.; on grassy hillsides, Glen Creek, June 29, 1899, Aven and Elias Nelson, No. 5559 (MBG 84542, UMH); on the moist slopes, Telephone Mines, Albany County, August 1, 1900, Aven Nelson, No. 7900 (MBG 84540, UMH); head of Muddy River, May 4, 1860, Dr. F. V. Hayden (MBG 84135); Gros Ventre Fork, Wind River Mountains, on gravelly hills, alt. 6,800 ft., June 5, 1860, Dr. F. V. Hayden (MBG 84136 and 84137).

UTAH: moist rocky soil, L.a Sal Mountains, alt. 9,000-10,000 ft., June, 1899, C. A. Purpus, No. 6625 (MBG 84424); Fish Lake Mountain, alt. 11,500 ft., July 8, 1875, L. F. Ward, No. 324 (MBG 776622).

Colorado: foothills west of Fort Collins, alt. 5,500 ft., May 7, 1896, C. F. Baker (MBG 84435); Grand Mesa, alt. 9,000 ft., June 23, 1901, region of the Gunnison watershed, C. B. Baker, No. 232 (MBG 84539, UMH); near Pagosa Peak, ali. $11,500 \mathrm{ft}$., August, 1899, C. F. Baker, No. 375 (MBG 83888); Howe's Gulch, five miles west of Fort Collins, alt. 5,500 ft., May 20, 1893, C. F. Baker, No. 3171 (UMH); Marshall Pass, region of the Gunnison watershed, alt. $10,000 \mathrm{ft}$., July 19, 1901, C. F. Baker, No. 493 (MBG 84541). (Plant on this sheet is very similar to Baker's No. 509, Small's type of $S$. arnoglossa); Bear Creek Divide, west La Plata.Mountains, alt 11,500 ft., June 29, 1898, Baker, Earle, and Tracy, No. 227 (MBG 84101, MBG 84433, UMH) ; Breckenridge, 1887, S. D. Bereman, No. 731 (MBG 84578); summit Pike's Peak, July 29, 1901, F. E. and E. S. Clements, No. 430 as S. interrupta nana. (MBG 83890, UMH) ; Seven Lakes, alt. 3,500 m., July 8, 1901, F. E. and E. S. Clements, No. 442 (UMH, MBG 83889) ; foothills, alt. 6,000 ft., May 5, 1896, C. S. Crandall (MBG 84428); in rather dry woods, Berthoud's Pass, as "Saxifraga nivalis Lin. forma minor compacta." (MBG 84253); no locality, September 14, 1874, G. Engelmann (MBG 84181) ; Gray's Peak, July 16, 1891, no collector cited, ex herbarium Fritchey, 1891 (MBG 84074) ; semi-meadow. Rabbit Ear Range, Routt County, July 17, 1803, L. N. Gooding, No. 1582 (MBG 84093) ; Pike's Peak, alt. 12,000 ft., August 13, 1884, G. W. Letterman, No. 154 (MBG 84423) ; as S. nivalis L.; Gray's Peak, No.- date, G. W. Letterman, "S. nivalis" (MBG 777454); Manitou Trail to Pike's Peak at timber line, August 13, 1884, G. W. Letterman (MBG 777456); foothills, Larimer County, May, 1893, G. E. Osterhout (UMH) ; Tolland, dry sandy lowlands, alt. 9,000 ft., June 27, 1913, L. O. Overholts, No. 10026 (MBG 743694); from the headwaters of Clear Creek, and the alpine ridges lying east of Middle Park, 1861, C. C. Parry, No. 169, "S. nivalis L." (MBG 84240); Mt. Baldy, alt. 11,000 ft., July 11, 1891, 
E. C. C. (MBG 84421); Snow Edge, July 6, 1886, and Leadville, August 8, 1886, Wm. Trelease (MBG 84436); Kempton, Mineral Pt., alt. 11,600 ft., June 20, 1887, ex herbarium, Trelease.

New Mexico: Pecos River, July 4, 1898, G. E. Coghill, No. 54 (MBG 83873); Santa Fe Mountains, August, 1884, F. H. Snow (MBG 776638); Pecos River National Forest, approximate alt. 12,000 ft., July 11, 1908, Paul C. Standley, Na. 4315 (MBG 84082).

Saxifraga hieracifolia Waldst. and Kit., Pl., Hungar. 1:17, Table XVIII. (Unverified.)

Micranthes hieracifolia Haw., Saxifr. Enum. 45. 1821.

Saxifraga nivalis var. racemosa, Towns, it. Hung. 486.

Saxifraga rigida, Chr. Sm., in Herbarium DC., ex Engler, Monogr. Saxifr. 151. 1872, as synonym.

Saxifraga uliginosa, Fisch., in litt. 1829. Engler, l.c., as synonym.

Saxifraga plantaginifolia Hook., in Parry's Voyage, appendix 394.

Evaiezoa hieracifolia Raf., F1. Tell., 2:70. 1836.

(Plates XI, V, VII.)

Specimens examined:

Alaska: Hall Island, July 14, 1899, Wm. Trelease, No. 4035, as S. hieracifolia W. and K. (MBG 83975) ; Port Clarence, July 12, 1899, Wm. Trelease, No. 4936, as S. hieracifolia W. and K. (MBG 83976) ; St. Matthew Island, July 15, 1899, Wm. Trelease, No. 4037, as S. hieracifolia W. and K. (MBG 83975) ; St. Matthew Island, August 11, 1891, J. Macoun No. "55" (MBG 83978); Oglamie, Pt. Barrow, Arctic Sea, lat. $71^{\circ}, 1883, D r$. John Murdock, No. 15704, ex herbarium, Dr. A. Gray as S. hieracifolia W. and K. (MBG 83977); "Alaska," Mr. Reaman, as S. nivalis L., Herbarium of Dartmouth College. Caulescent, leaves more deeply dentate.

It is very doubtful whether these specimens are actually Saxifraga hieracifolia $\mathrm{W}$. and $\mathrm{K}$. Owing to conditions incident to the World War it has been impossible to obtain authentic material from Hungary (the type locality) for comparison. The specimens at hand are very different, however, from a Norwegian specimen in the Herbarium of the University of Minnesota. The latter has broad elliptic-ovate leaves on short petioles, and possesses a distinctly raised gland which persist sas a flange around the carpels, a condition not found in the Alaskan specimens. In the characters of the petals, sepals, and hairs, however, the two plants are similar. The gland of the Alaskan specimens is conspicuously depressed and smooth in the early stages, and the flowers are characteristically stellate. It was the form of the petals no doubt that led Hooker (16) to infer that the American plant, to quote his words, "appears exactly intermediate between $S$. pennsylvanica and $S$. nivalis, more allied, however, to the former" but its deep receptacle, flat, appressed, discoid gland, and stout erect follicles indicate no very close relationship to either, petal-form in this case furnishing no criterion of relationship. Furthermore, the American specimens do not 
possess the plantagineous leaves that might suggest the $S$. plantaginifolia of Hooker (In Parry's Second Voyage, appendix 394), although this form of leaf is characteristic of the Norwegian specimen. Hooker's (16, p. 49), description reads "foliis petiolatis obovato-spatulatis repandodentatis." In a specimen cultivated by himself, HAwORTH (14) found the leaves to be "lanceolata obtusa subavenia crassiuscula,"-not so different from Willdenow's description "foliis oblongo-lanceloatis glabris repando-dentatis."

Saxifraga franciscana (Small) Fedde, Just, Bot. Jarhesb. 33:1:613. 1906.

Micranthes franciscana Small, N. Am. F1. 22:2:144. 1905.

(Plates XI, VIII-X.)

Specimens examined:

ArIzona: San Francisco Mountains, alt. 11,500 ft., August 27, 1889. F. $H$. Knowlton, No. 127, as $S$. nivalis L., referred to this species by ENGLER and IRMSCBER on sheet No. 258261 (USNH).

The following specimen is doubtfully referred here:

CAlifornia: Mt. Goddard, Sierra Nevada Mountains, alt. 11,500 ft., July 24-26, 1900; Hall and Chandler, No. 70y, as S. nivalis L. (UMH). This plant differs from the above in having a wholly glabrous, purple, and taller $(11 \mathrm{~cm}$.) scape, and a fewerflowered, less compact inflorescence. The differences in the floral characters are very slight and difficult to detect. The beaks are shorter, and the gland seems to persist as an inconspicuous flange above the base of the calyx. No seeds.

Section Micranthes (Haw.) Tausch, Hort. Canal., fasc. 1. 1823.

Micranthes Haw., Syn. P1. Succ., 320. 1812; as genus.

Boraphila Engler, Verh. Zool.-Bot. Ver., Wien. 19. 1869; in part.

Micranthes Small, N. Am. Fl., $22: 2: 132$. 1905; in part.

Ovary subinferior; receptacle bowl-shaped, shallow to deep. Gland fleshy, broad, discoid, and almost completely enveloping the ovary, and usually considerably raised above the base of the calyx, its surface at length conspicuously convoluted and verrucose, and its lower margin persisting as a distinct flange around each carpel. Carpels distinct, but connected by the adnate receptacle and at least the basal portion of the gland. Filaments subulate, flattened, uncinate. Sepals spreading or reflexed. Petals lanceolate to orbicular. Seeds various, tuberculate to smooth, in some forms winged. Inflorescence paniculate to corymbose, the cymules often glomerate. Hairs uniseriate, the glands various (Plates II, III, XII, XVIII).

HAwORTH (13) founded his genus on Saxifraga pennsylvanica, distinguishing it by its "lorate" petals ("petala lorata distantia"). TAUSCH (30) included $S$. nivalis L., apparently on the similarities in the calyx, but he erroneously describes the seeds as smooth. SERINGE (26) included $S$. virginiensis Michx., S. davurica Pall., and S. hieracifolia W. and K., on the 
same grounds, apparently, that TAUSCH included $S$. nivalis, but in the case of $S$. davurica he was probably misled by inadequate material, as the species properly belongs in the section Hydatica. LEDEBOUR (18) combined the section with Arabisa of TAUSCH on the non-stoloniferous habit. TORREY and GRAY (31) included S. erosa Pursh (S. micranthidifolia Haw.) with some hesitation.

Hooker (16) made no mention of this species but included a new one which he had named Saxifraga reflexa. Finally Small (27) adopted Micranthes (Haw.) as a generic name for a combination of HaworTH's genera Robertsonia, Dermasea, and Aulaxis, and RAFinesoue's (24) genus Steiranisia. In that sense SMALL's genus was synonymous with the sections Micranthes and Hydatica of TAUSCH and his followers. The result was an aggregation of species of widely different floral characteristics.

The section Micranthes contains the majority of those species with a deep receptacle in which the tendency toward epigyny has advanced the farthest and which are further characterized by the conspicuous, fleshy, discoid gland which is elevated a considerable distance above the base of the calyx, and which persists as a distinct flange around the carpels at maturity. The gland is the most distinctive characteristic of the section.

In Saxifraga pennsylwanica and S. californica the gland is more elevated than in the other species. Other minor distinctions appear here and there. A reference to the plates will show the striking similarities in the glands and carpels, particularly in S. integrifolia, S. nidifica, and S. montanensis.

The carpels are distinct to the base but are connected laterally by the adnate receptacle and at least by the lower portion of the gland. In some cases as in $S$. pennsylvanica, $S$. Sierrae, and $S$. oregana, the receptacle does not keep pace with the growth of the carpels so that as the follicles are pushed apart at maturity the receptacle is compressed and gives the appearance of a completely hypogynous condition.

As a whole the section presents the most difficult problem in the entire series. Polymorphism appears to be a general characteristic and complicates the situation. In no other group, it appears from the herbarium specimens, have botanists been so at variance on the question of species.

Two main types of petals occur, the narrowly lanceolate and the orbiculate. Between these there are many variations. The strictly lanceolate type is restricted exclusively to the eastern species, namely to $S$. pennsylvanica and its allies. The extreme orbiculate type is represented by $S$. californica and $S$. napensis. Curiously enough the orbiculate type is as constant at this extreme as the lanceolate type at the other. In the group represented by $S$. integrifolia the variations of petal-form are perplexing in the extreme. 
Clavate filaments do not occur in the section. The subulate type present is usually flattened with age and incurved more or less sharply at the top.

The receptacle is typically bowl- or urn-shaped, but varies considerably within certain groups, such as that represented by $S$. integrifolia. The relative depth of the receptacle furnishes a basis for dividing the species into two principal divisions.

Variations in the inflorescence are also marked within certain limits, not only as between immature and mature stages but as between individuals of the same species, as in S. nidifica and $S$. pennsylvanica. The writer has not been able to determine whether the latter type is a specific or merely an individual variation. A well-defined corymbose inflorescence occurs in $S$. fragosa and $S$. napensis. Glomerate cymules are characteristic of $S$. nidifica and its allies.

Seed characters appear to be quite constant within certain groups. Thus, winged seeds are characteristic of $S$. Sierrae and related forms, and tuberculate seeds of $S$. pennsylvanica and its allies. Intermediate forms seem to show varying types, but in most cases the material has been deficient in mature specimens. Several types of seeds have been found in specimens referred to $S$. pennsylvanica.

The principal categories have been founded on the relative depth of the receptacle-one shallow, the other deep. The species of the first division are separated into two categories on the basis of petal-form, the first comprising all the species which have typically lanceolate petals, namely $S$. pennsylvanica and allies, the second comprising a half dozen species which have orbiculate or ovate petals, namely $S$. Sierrae and $S$. californica and their allies. Characters of the follicles, petals, and leaves, since they are constant within the limits indicated, serve to separate the minor categories of each group, respectively. Finally the specific distinctions are based on certain vegetative and floral characters that are well marked. In the second division some differences in the gland occur, showing two lines of development, one in which the type has remained constant, the other in which it has become considerably narrowed, at least as far as could be determined from the material available. The latter group is limited to a single species. The remaining species, only six in number, are grouped in two categories on the basis of the colors of the flowers. Characters of the petals serve to separate the species of the first category. The species of the second category fall into two equal groups on characters of the inflorescence, in which the species are designated by characters of the inflorescence and leaves. An attempt has been made to arrange the species according to their affinities, and if the specimens be laid out in series according to the accompanying analytical key the significance of the arrangement may be evident. 
Geographically the species are almost wholly confined to the United States. There are two well-marked distributional belts practically within the same latitudinal range, one eastern, the other western. The eastern belt runs westward from New Hampshire and Massachusetts into Minnesota, Iowa, and Missouri, occupying practically all the area between the Great Lakes and the Ohio River, with a narrow strip in Canada along Lake Erie and Lake Ontario. The belt is dominated by $S$. pennsylvanica. At the extremities of the range certain peculiar types have been differentiated, to which may be added certain apparently distinct types from the center of the range. The exact status of these types can not be established at present. An interesting feature in this connection is the remarkable similarity between certain specimens from the Yellowstone National Park region and a specimen from the Winnebago Valley in Minnesota.

The western distributional belt lies in the form of a deep inverted crescent, the points of which rest on the same parallel of latitude, on the southern boundary of Colorado, in the Rocky Mountains, and a short distance north of Tulare Lake, California, respectively. The arms of the crescent follow the courses of the mountains northward, with the main body occupying the watershed of the Clark's Fork, the Clearwater, and the Snake rivers, and the lower course of the Columbia. A small, apparently detached belt, occupied by a single species, surrounds the shores of Puget Sound. This large crescent-shaped belt almost completely surrounds the Great Basin. Practically nothing is known concerning the exact limits of the ranges of the individual species, particularly the western ones, as the collections are in most cases very meager. The species on the whole are plants of the lower altitudes, not a few being marsh plants.

\section{Key to THE SPECIES}

I. Receptacle ccmparatively shallow; follicles spreading and often apparently superior at maturity

A. Petals narrowly lanceolate

a. Follicles and beaks elongate

1. Petals white; follicles green

(a) Branches of inflorescence diffuse and delicate..........S. Forbesii

(b) Branches of inflorescence stout, ascending.........S. pennsylvanica

2. Petals purple................................. purpuripetala

b. Follicles globose, inflated; brownish

1. Follicles large, stout; beaks thick................... crassicarpa

2. Follicles small; beaks very short.................. v. vinnebagoensis

B. Petals orbiculate to oblong

a. Leaves elongate, of a lanceolate type; tall species

1. Leaves narrowly lanceolate or oblanceolate; petals oblong.....S. oregancs

2. Leaves broader and mostly shorter; petals ovate or orbiculate..S. Sierrae 
b. Leaves of an ovate type

1. Leaves small, sharply dentate

(a) Leaves shallowly dentate to subentire; petals oblong.....S. parvifolia

(b) Leaves coarsely and evenly serrate-dentate; petals elliptic. S. gracillima

2. Leaves larger, repand to sinuate dentate; petioles elongate

(a) Leaves glabrous, thin; petals ovate-lanceolate............ f. fallar

(b) Leaves pubescent; petals orbiculate to oval...........S. californica

II. Receptacle deeper; follicles not strongly spreading

A. Gland broad, fleshy, verrucose or convoluted, conspicuous

a. Flowers commonly greenish; cymules glomerate

1. Petals mostly shorter than the sepals, sometimes longer; inflorescence

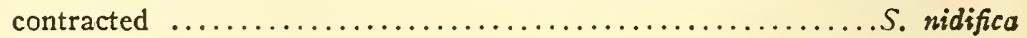

2. Petals mostly exceeding the sepals, or wanting; inforescence commonly

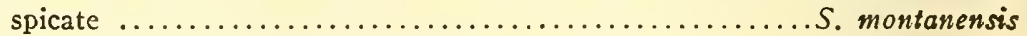

b. Flowers white, generally conspicuous

1. Inflorescence more or less contracted; cymules glomerate

(a) Inflorescence stout, thyrsoid; stout plants............. integrifolia

(b) Inflorescence delicate, subcapitate; delicate plants.........S. apricu

2. Inflorescence broad, corymbose; petals orbicular

(a) Leaves broadly ovate; flowers large................ fragosa

(b) Leaves narrowly ovate; flowers small................ napensis

B. Gland narrow, smooth; follicles short, purple, very smooth.......S. laevicarpa

Saxifraga Aprica Greene, Bull. Torr. Bot. Club 23 :25. 1896.

Saxifraga umbellulata Greene, Erythea $1: 222.1893$.

Micranthes aprica (Grreene) Small, N. Am. Fl. 22:2:135. 1905.

Specimens examined:

CAlifornia: wet shady places above Donner Lake, Nevada County, July 4, 1892, C. F. Sonne, No. 90 (MBG 84536) (doubtful) ; Mt. Eddy, Siskiyou County, August 18, 1903, Copeland, No. 3845, as Saxifraga midifica, det. Dr. Greene; distributed by C. F. Baker (MBG 84117); Siskiyou County, Mt. Eddy, in open gravelly places in the forest, alt. 6,800 ft., A. A. Heller, No. 12081.

Saxifraga Californica Greene, Pitt. 1:286. 1889.

Saxifraga virginiensis Benth., P1. Hartw. 311. 1848.

Micranthes californica (Greene) Small, N. Am. F1. $22: 2: 140.1905$.

Sarifraga virginiensis Michx. var. californica (Greene) Jepson, F1. Mid. Western Calif. 268. 1901.

Distribution.-Central California, north and south of a line between Lake Tahoe and San Francisco Bay.

Specimens examined:

CAliforniA : Mt. Tamalpais, March 30,1889, E. L. Greene (UMH) ; Sonoma County, March 13, 1892, Michener and Bioletti (UMH); near Clear Creek, Butte County, alt. 175 ft., April 1-15, 1897, H. E. Brown, No. 150 (UMH); Loma Prieta, Santa Clara County, eastern slope, April 1-7, 1894, J. Burt Davy, No. 476 (UMH); San Juan, San Benito, June, 1903, A. D. E. Elmer, No. 4911 (UMH, MBG 84118); Clinton, Amador County, Sequoia gigantea region, March 29, 1892, Geo. Hansen, No. 92 (UMH and MBG 84282); Mokelumne Hill, Calaveras County, alt. 2,000 ft., April 1, 1896, 
Geo. Hansen, No. 1533 (MBG 84283); woods near Cazadero, Sonoma County, April 24, A. A. Heller (MBG 84279); 1896, Mrs. R. M. Austin, No. 859 (MBG 84281); Alma, Santa Clara County, common about moist banks and thickets, March 23, 1902, C. F. Baker, No. 370 (MBG 84275) ; Sonoma Creek, eastern base of Mt. Hood, Sonoma County, March 12, 1892, Heller and Brozen, No. 5040 (MBG 84276); foothills west of Los Gatos, Santa Clara County, April 6, 1904, A. A. Heller (MBG 84280) ; Santa Rosa, Sonoma County, March, 1880; near Mariposa, Mariposa County, March and April, 1882; Glacier Point, Mariposa County, July 1, 1885; Mariposa, Mariposa County, May, 1886; Elk Grove, Sacramento County, March 31, 1894; south of Farrington, Stanislaus County, March 30, 1894; north of Folsom, Placer County, April 5, 1894, Stockton Creek, Mariposa County, April 20, 1889, Santa Rosa, Sonoma County, March 20, 1880; ex herbarium J.W. Congdon.

Saxifraga crassicarpa sp. nov.

Saxifraga pennsylvanica L., of authors in general.

Receptaculum ovarii parti inferiori adnatum; folliculi crassi subsphaerici stylis crassis valde divergentibus; stigmatibus crassis discoideis; filamenta subulata, angustata, $2.5 \mathrm{~mm}$. longa; sepala cuneata, acuta, base coalitiuscula reflexa; petala $3 \mathrm{~mm}$. longitudine angustatissime lanceolata, acuminata 1-nervia; semina ovalia conspicue tuberculata.

Receptacle shallow; follicles thick, stout, subspherical, beaks stout, strongly divergent; stigmas broad, thick, flattened; filaments $2.5 \mathrm{~mm}$. long, subulate, narrow ; sepals cuneate, acute, somewhat united at the base, reflexed about $2 \mathrm{~mm}$. long lateral nerves, 2 short; petals very narrowly lanceolate, acuminate, 1-nerved, about $3 \mathrm{~mm}$. long ; leaves 6-19 cm., uniformly ellipticlanceolate, purplish towards the base, thick, leathery, sparsely pubescent on both sides, minutely and rather distantly and evenly denticulate, obtuse, ciliolate, contracted into a short membranous margined petiole-like base; scapes stout, about $90 \mathrm{~cm}$. high, glandular-pubescent, more densely so above, branching from above the middle; inflorescence paniculate-cymose, branches elongate, slender, ascending, bearing the few-flowered cymules towards the ends; perennial from a stout, woody caudex.

The follicles of this plant are very different from the common Saxifraga pennsylvanica; they are very stout, globose, and thick-beaked. The seeds are relatively large and conspicuously tuberculate. The few-flowered coarse inflorescence is also characteristic (Plate XII).

Distribution.-As far as known occasional from northeastern Minnesota to north central Illinois.

Specimens examined:

Mrnnesota: St. Louis River, July 23, 1886, Arthur, Bailey, and Holway, No. B329 (UMH).

Wisconsin: swamps in Mirror Lake, Sauk County, July 14, 1903, H. Eggert (MBG 83863); Walworth County, common in low grounds among thickets, near Lake Beulah, July 26, 1905, James I. Shannon, No. 125a (MBG 84478, 84479). 
Iulinors: wet prairie near Wady Petra, Stark County, May 12, 1897, Virginius H. Chase (MBG 84469).

Saxifraga fallax Greene, Bull. Torr. Bot. Club 23 :25. 1896.

Micranthes fallax (Greene) Small, N. Am. Fl. 22:2:141. 1905.

A delicate species of the aspect of Saxifraga Careyana Gray (Plate XIV).

Distribution.-Not definitely known. "Oregon and California" according to Small (l.c.).

Specimens examined:

Carifornia: Emigrant Gap, July 1, 1882, Marcus E. Jones, No. 3587, as S. fallax Greene by ENGLER and IRMSCHER (USNH 221361).

SAXifraga Forbesil Vasey, Am. Entom. and Bot. 2 :288. 1870.

Saxifraga pennsylvanica L., Sp. Pl. 399. 1753.

Distribution.-Not definitely known; apparently limited mostly to eastern Missouri, through St. Louis and Jefferson counties, and adjacent counties in Illinois.

Specimens examined:

MissourI: wet shaded sandstone cliffs, Silica, Jefferson County, May 5, 1898, Colton Russell (MBG 83960); Silica, May, 1890, ex herbarium Frederick Wislizenus, No. 939 (MBG 84580); rocks, St. Louis, May, 1887, H. Eggert (UMH); Jefferson County "Sandfelsen," May 11, 1887, H. Eggert (MBG 83856, 739323); St. Louis, shady rocks, May and July, 1880, H. Eggert (MBG 84582); Pacific, Franklin County, May 8, 1896, H. Eggert (MBG 738820, 83861) ; St. Louis, shady sandstone, July, 1880, H. Eggert (MBG 83857) ; Jefferson County, May 11, 1887, H. Eggert (MBG 83862); St. Louis County, on the Meramec, under shady rocks, June 15, 1875 (MBG 83820); April 15, 1880 (MBG 83858); June 20, 1884 (MBG 83859), with large foliaceous bracts; Allenton, June 20, 1880 (MBG 772053, 780787) ; April 16, 1880 (MBG 775263, 83818), wet sand rocks, G. W. Letterman (MBG 777205).

Illinors: June, 1875, D. G. Vasey (MBG 84223) ; Makanda, "type locality," on moist cliffs, May 5, 1900, Baker, No. 6168 (MBG 83868).

Saxifraga fragosa Suksdorf ex Small, Bull. Torr. Bot. Club $23: 363$. 1896.

Saxifraga claytoniaefolia Canby, Small, Bull. Torr. Bot. Club 23:365. 1896.

Saxifraga integrifolia var. fragosa (Suks.) Rosendahl, Beibl. Bot. Jahrb., Nr. 83. 1905.

Sa.rifraga integrifolia Hook. var. claytoniaefolia (Canby) Rosendahl, l.c.

Micranthes claytoniaefolia (Canby) Small, N. Am. F1. 22:2:141. 1905.

Saxifraga fragosa var. leucandra Suks., in herb.

Distribution.--"Washington to Oregon" (Small), l.c.

Specimens examined:

Washington: wet rocks near the Columbia River, Klickitat County, May, 1892, W. N. Suksdorf, No. 1727 (MBG 84331, UMH) ; wet mossy cliffs, Almota, Whitman County, May, 1897, A. D. E. Elmer, No. 139 (UMH). 
Oregon: the Dalles, Wasco County, April 19, 1902, E. P. Sheldon, No. 10109 (UMH and MBG 83872).

Saxifraga gracillima sp. nov.

Receptaculum ovario infra medium adnatum, ovariis depressis in glandula latissima profunde insertis, folliculi parvi inflati, superne valde contracti, stylis primum gracillimis demum plus minusve abbreviatis divergentibus, stigmatibus globosis, filamenta subulata apice valde incurvata carpidiis supercurrentia, sepala parva ovatave cuneata base minime coalita 1-nervia, petala elliptica vel elliptico-lanceolata sepalis multi longiora base valde contracta.

Receptacle adnate to the ovary below the middle; ovary depressed, inserted deeply in a very broad gland; follicles small, inflated, strongly contracted above styles, at first very slender, at length shortened and recurving, globose; filaments subulate, strongly incurved at apex and exceeding the (young) carpels; sepals small, ovate or cuneate, slightly united at the base, 1-nerved; petals elliptic or elliptic-lanceolate, much longer than the sepals; strongly contracted at the base.

Leaves basal, $1.5-5 \mathrm{~cm}$., ascending-spreading, ovate, smaller, sometimes elliptic, coarsely serrate-dentate, thin, acute, sometimes purplish, margins ciliolate or not at all so, abruptly contracted into a very slender petiole about equalling or sometimes exceeding the blades. Scapes erect or assurgent, very slender to delicate, commonly solitary, $15-22 \mathrm{~cm}$. high, thinly glandular-pubescent, cormybosely branched above; branches of the inflorescence few and filiform; flowers white, conspicuous, not numerous, in loose, open cymules. Bracts small to minute, especially the upper, sparsely-ciliolate on the margins. Perennial from a short, slender, fibrous-rooted caudex. A graceful, delicate species. The relatively large petals, very small carpels and calyx-lobes, and the strongly serrate-dentate leaves with their slender petioles are the most obvious characteristics. The shallow receptacle gives the appearance of a hypogynous condition with age. There is great variation in the size of the petals in different flowers. Mature fruit not seen (Plate XIV).

Distribution.-Known only from type locality.

Specimens examined:

Calirornia: Cañon of Big Chico Creek, Butte County, March 19, 1914, A. A. Heller, No. 11214, as Micranthes californica (Greene) Small, Type (UMH, MBG 745924). Plants on MBG sheet smaller than the specimens in the Herbarium of the University of Minnesota.

Saxifraga integrifolia Hook., Fl. Bor. Amer. 1 :249. 1840.

This species appears to be a perplexingly polymorphic one. Such has been the confusion in regard to it that identical forms have been variously 
referred to Saxifraga fragosa, S. Sierrae, S. oregana, S. bracteosa, $S$. plantaginea, and $S$. nivalis. A single specimen from Forest Grove, Oregon, (Prof. Joseph Marsh, No. 85) which appears the closest to S. integrifolia Hook. as to leaf characters, differs radically from that species in carpels and petals. In spite of the excellent delineations in Hooker's (16) plates the fact remains that no such fruit or carpels occur in the entire section Micranthes, as are portrayed in Figures 2, 4, and 5 of Hooker's Plate LXXXVI. HookER's figures fail to show the characteristic broad gland surrounding the carpels and so generally well-marked in the section Micranthes; moreover Figure 4 (and to less extent Figure 5) portrays the carpels as united above the middle, which is not the case except as they are adnate laterally to the gland. This and the further fact that Figure 4 (and to less degree Figure 5) portrays the carpels as seated in a deep receptacle are both contradictory of the description "ovario omnino libero" (Vol.1:249). Figure 5 might well belong to such species as S. saximontana (Sect. Dermasea) or $S$. rhomboidea (Sec. Chionophila). No plants have been found that conform to Hooker's characterizations of the leaf-margins as "integerrimis" (Plate XVI).

The region about the lower Columbia River whence Dr. Scouler's plants came needs to be thoroughly explored, and the original collection studied, in order to establish the identity of this species.

For the present Saxifraga bracteosa Suksdorf and its varieties are included in this species. Better material is necessary to establish the exact status of $S$. bracteosa but as far as can be determined there is no essential difference between it and specimens from the same locality that have been referred to $S$. integrifolia Hook.

Saxifraga laevicarpa sp. nov.

Folliculis brevibus inflatis laevibus purpureis receptaculo infra medium insertis, stylis brevibus valde divergentibus vel recurvatis, glandula laeve crassa angustata elevata, filamentis subulatis superne attenuatis incurvatis antheris parvis marginibus purpureis; sepalis virideis vel purpureis $2 \mathrm{~mm}$. longis angustatis cuneatis vel deltoideis base coalitiusculis acutis reflexis, petalis $3-4 \mathrm{~mm}$. longis purpureis perangustatis lanceolatis acutis 1-nerviis base contractis; seminibus crassis ovatis saepe angulatis carinatis sulcatis evidente tuberculatis.

Follicles short, inflated, smooth, purple, inserted below the middle in the receptacle; styles short, strongly divergent or recurved; gland smooth, thick, narrow, elevated; filaments subulate, attenuated above, incurved, anthers small, the margins purple; sepals green or purple, $2 \mathrm{~mm}$. long, narrow, cuneate or deltoid, somewhat united at the base, acute, reflexed; petals 3-4 mm. long, purple, very narrow, lanceolate, acute, 1-nerved, contracted at the base; seeds thick, ovoid, often angled, carinate, sulcate, tuberculate. 
Leaves $2-4 \mathrm{~cm}$., narrowly ovate, dull green to purplish, glabrous or nearly so, shallowly denticulate, margins sometimes irregular, contracted into a slender petiole about equalling the blade. Scapes $25 \mathrm{~cm}$. or shorter, solitary, erect, purplish, rather copiously glandular-pubescent. Inflorescence racemose or somewhat spicate, elongate to shorter; cymules contracted or glomerate, apparently sessile, the lower much shorter than the elongate internodes; flowers white, rather few. Bracts lanceolate, small. the lowest about $8 \mathrm{~mm}$., purplish, equalling or exceeding the small glomerate cymules. Perennial by a short, fibrous-rooted caudex.

Distinctive features: purple, smooth carpels with widely divergent to recurving beaks and the peculiar thick, smooth, flange-like gland (Plate XVII).

Distribution-Puget Sound region.

Specimens examined:

Washington: Friday Harbor, April 3, 1910, Wm. Moodie. Type! Tacoma, May 11, - T. C. Frye.

Saxifraga montanensis Small, Bull. Torr. Bot. Club 23:56:367. 1896.

Saxifraga subapetala E. Nelson, Erythea $7: 169.1899$.

Micranthes montanensis Small, N. Am. Fl. 22:2:139. 1905.

Micranthes subapetala (E. Nels.) Small, l.c.

Micranthes brachypus Small, l.c. (Unverified.)

This seems to be a good species, but it intergrades strongly with the more western $S$. columbiana Piper, and $S$. plantaginea Small (here included under S. nidifica Greene, q.v.), while some forms that have been referred to S. montanensis Small, by some authorities, closely approximate Micranthes arnoglossa. Small in floral characters. The species can not be distinguished from E. Nelson's S. subapetala, but the leaves of the latter have longer petioles. Other specimens are difficult to distinguish from Suksdorf's $S$. bracteosa (No. 1728) from the Columbia River, West Klickitat County, Washington.

Small's species is based on Mr. Frank Tweedy's No. 58, collected in southwestern Montana in July, 1888 . The original description is greatly at variance, however, with the later one in North America Flora 22:2:139. 1905. It is difficult to connect the two with the same plant, and leads to the suspicion that Tweedy's No. 58 is not the plant that the author in his later work considers to be Micranthes montanensis.

Distribution.-Region of Yellowstone National Park; limits of range not definitely known.

Specimens examined:

Montana: Bozeman, meadows June 14, 1905, Blankinship, No. 521 (doubtful); Spanish Basin, Gallatin County, alt. 6,500 ft., June 30, 1897, Rydberg and Bessey, No. 4263, referred to S. montanensis by ENGLER and IRMSCHER (USNH 360877) (doubtful). 
Wyoming: near Manımoth Hot Springs, alt. 6,000 ft., July, 1893, and 7,000 ft., July, 1893, both along meadow borders, F. H. Burglehause (UMH); Mammoth Hot Springs, July, 1893, F. H. Burglehause, referred to S. montanensis by ENGLER and IRMSCHER (USNH 45808).

Saxifraga Napensis Small, Bull. Torr. Bot. Club 25:316. 1898.

Micranthes napensis Small, N. Am. Fl. 22:2:140. 1905.

A tall graceful species bearing a strong resemblance to Saxifraga fragosa Suks. It is based on a collection of J. W. Bigelow (Whipple's expedition) and George Thurber No. 496 (Small, l.c.), Napa Valley, California. There is a discrepancy between the original description (l.c.) and that in the North American Flora (l.c.). In the latter the petals are described as "wanting." The descriptions of the calyx and the carpels also differ. The leaves are described as pubescent. In the specimens cited below they are glabrous. No mature fruit available (Plate XVII).

Distribution.-Not definitely known; apparently restricted to a small region north of Tulare Lake, California. "California," according to Small (l.c.).

Specimens examined:

California: region of Dinkey Creek, Fresno County, alt. 7,500 ft., June 25, July 15, 1900, Hall and Chandler, No. 386 (UMH, two sheets; MBG 84426).

Saxifraga nidifica Greene, Erythea 1:222. 1893.

Saxifraga plantaginea Small, Bull. Torr. Bot. Club $23: 366.1896$.

Saxifraga columbiana Piper, Bull. Torr. Bot. Club 27:393. 1900.

Micranthes colmmbiana (Piper) Small, N. Am. F1. 22:2:135. 1905.

Micranthes plantaginea Small, l.c.

Receptacle deep; ovary deeply immersed in the gland; follicles stout, erect or not strongly spreading; beaks stout, spreading; stigmas globose, at length flattened, thick. Gland conspicuous, fleshy, at length rugose, verrucose or convoluted, the margin lobed, at first crowding the base of the calyx, at length elevated and persisting as a distinct flange around the follicles. Filaments subulate, flat, uncinate, mostly shorter than the sepals, often very short; anthers commonly large, the margins purple with age. Sepals 1.5-3.0 mm., oblong to triangular-ovate or deltoid, at length reflexed, acute to obtuse or rounded at apex, margins entire or denticulate; 1-2 nerved, occasionally more, the nerves simple or branched, reaching to or beyond middle, free or uniting with the mid-nerve below the apex. Petals $1-3 \mathrm{~mm}$., sometimes very small to minute, oblong, elliptic, obovate to spatulate-orbicular, varying greatly in the same individual and even in the same flower; acute, obtuse, to rounded and retuse at apex, orbicular forms with a more or less clawlike base; mid-nerve simple or with one or more elongated branches, these sometimes coalescing with mid-nerve below apex. Seeds thick, fusiform, sometimes pointed or slightly winged at the ends and marked with more or less 
prominent longitudinal ridges of inconspicuous tuberculate teeth, or nearly smooth or striate. Leaves $2-10 \mathrm{~cm}$., lanceolate to oblong or ovate, varying considerably, mostly glabrous, margins ciliolate and obsoletely denticulate to sinuate or rarely dentate. Scapes about $45 \mathrm{~cm}$. high and less, stout, erect, finely glandular-pubescent, more copiously so above, branched near the top or occasionally with one or two long slender branches arising from below the middle. Inflorescence paniculate-cymose, compact and spicate in some forms to open and branched below; upper cymules mostly sessile or nearly so, glomerate. Perennial from a short, stout caudex; sometimes a cluster of reddish bulblets at the base of the scape.

GreENE's (11) original specimens of $S$. nidifica have not been available, but his description of it (l.c.) indicates that it is identical with $S$. plantaginea Small and S. columbiana Piper. The mass of bulblets noted by Greene at the base of the scape in his plants is also to be found in the specimens of $S$. plantaginea from Spokane, and in plants from Idaho and Montana. Small (27) separates $S$. nidifica from $S$. plantaginea by its "arachnoid" as well as glandular pubescence, while the latter is regarded as being merely glandular-pubescent, a distinction which does not hold since both kinds of hairs occur in specimens of $S$. plantaginea from Montana and Idaho.

More or less confusion has also prevailed as to the distinctions between S. plantaginea and S. columbiana. S. plantaginea is based on Sandberg and Leiberg's collection of May, 1893, from Spokane, Washington. The species is distinguished, according to SMALL, by its "broad greenish petals which are exceeded by the calyx." Later PIPER (22, p. 393) based a new species, $S$. columbiana, on specimens from the same region, which he differentiated from $S$. plantaginea Small on size, and on the characters of the petals, the latter, he writes, being "a larger plant in every way," with "white, elliptic or oblong, 1-nerved" petals. Comparing the cotypes and other authentic specimens it is found that Piper's own collection of $S$. columbiana, namely No. 1808, from Pullman, Washington, is a larger plant than any of the specimens of $S$. plantaginea, Small; at the same time other collections, identical with Piper's No. 1808, from adjacent localities in Idaho and western Montana, show the same characteristics as to size (Heller No. 3037, Lewiston, Idaho; Sandberg, Kootenai County, Idaho, July, 1887; Williams No. 401, Columbia Falls, Montana). Another specimen collected by Piper at Pullman, Washington, May 24, 1894 (without number) and identical with his No. 1808, can not be distinguished from the cotype of S. plantaginea (namely that of Sandberg and Leiberg, Spokane, Washington, May, 1893). A detailed examination of a great deal of material of the two species shows the petals to be extremely variable and therefore wholly unreliable as specific characters (Plate XV). 
Distribution.-Montana, northern Idaho, and eastern Washington to Nevada. Limits of the range not definitely known.

Specimens examined:

Washington: Spokane, alt. 1,200 ft., May, 1893, Sandberg and Leiberg (UMH); Spokane, alt. 1,000-2,000 ft., May, 1893, Sandberg and Leiberg (UMH) ; Spokane, alt. 2,000-3,000 ft., May, 1893, Sandberg and Leiberg (UMH, MBG 84123); Hangman Creek, Spokane County, alt. 1,510 ft., May 16, 1893, Sandberg and Leiberg, No. 16 (MBG 84560); in pebbly moist hillsides, Pullman, May, 1897, A. D. E. Elmer, No. 126 (UMH, MBG 83874); on springy hillsides, Pullman, May 24, 1894, C. V. Piper, No. 1808 (UMH).

IDAно: moist hillsides, Lewiston, April, 1892, J. H. Sandberg (UMH); Nez Perces County, May, 1892, J. H. Sandberg (MBG 84422, UMH); meadows Kootenai County, May, 1891, J. B. Leiberg, No. 81 (UMH) ; grassy slopes, upper ferry, Clearwater River above Lewiston, April 30, 1892, Sandberg, MacDougal, and Heller, No. 73 (MBG 775340) ; about Lewiston, Nez Perces County, alt. 1,500-2,000 ft., May 7, 1896, A. A. and E. G. Heller, No. 3037 (MBG 83886, UMH).

Saxifraga OREgana Howell, Erythea 3:34. 1895.

Micranthes oregana (Howell) Small, N. Am. Fl. 22:2. 1905.

This tall species differs from its allies by its very shallow receptacle, elongated seeds, and long, narrow, oblanceolate leaves which are wholly entire. The flattening of the receptacle by the subsequent growth and wide divergence of the follicles produces a nearly hypogynous condition which was clearly pointed out by Howeln (17) as follows: "calyx attached to the ovary at the very base." To this species PIPER (21) referred Suksdorf's No. 1729 and Henderson's No. 2488 both of which, in leaf characters differ radically from Howell's specimens, although very similar as to inflorescence. The receptacle also is deeper and broader than in Howell's plant, the petals consistently narrower, and the seeds narrower and more winged at the ends. SMall (27) attributed the elongated narrow leaves of Howell's plant to its growing in water, but this hardly accounts for the differences in the receptacle. The description of Micranthes oregana Howell in North American Flora $22: 2: 138,1905$ is decidedly at variance with Howell's original description, from which it might be inferred that it was based not on Howell's specimens, but on Suksdorf's No. 1729, a plant referred to S. oregana Howell by Piper (Plate XIII).

Distribution.-Known only from the type locality.

Specimens examined:

Oregon: Lake Labish near Salem, June 21, 1893, Thos. Howell, No. 1498, ex herbarium, J. W. Congdon (UMH, MBG 84460).

Saxifraga PARvifolia Greene, Pitt. 3:116. 1896-1898.

Micranthes parvifolia (Greene) Small, N. Am. Fl. 22:2:141. 1905. 

(l.c.).

Distribution.-Not definitely known. "Oregon to California" according to Small

Specimens examined:

Oregon: Grant's Pass, April 13, 1887, Thos. Howell, No. 1134, as Saxifraga virginiensis Michx., var. (MBG 84381).

Dr. Greene's type specimen was collected by Howell at Grant's Pass, Oregon, 1892. No specimens of this collection have been available, but the above-named specimen agrees with Greene's description (Plate XIV).

Saxifraga pennsylvanica L. Sp. Pl. 399. 1752.

A detailed study of a great deal of material that has passed among herbaria as $S$. pennsylvanica has disclosed a number of very different forms which the writer suspects may prove to be sufficiently distinct to merit specific rank. The differences are most marked in the carpels, gland, and seeds, but are also plainly evident in the leaves and the inflorescence. As far as can be determined these forms differ also in their habitat, which is significant and calls for investigation. Before their status can be determined it will be necessary also to see the Linnean type. Certain obvious variations were noted by the early botanists; thus MicHaux (19) in a note writes as follows: "Variat floribus in ramis paniculae conglobatis et corymbosis." These forms were given varietal rank by SeRINGE (26) : (a), conglomerata and (b), corymbifera, respectively, the former having a dense panicle and conglomerate flowers ("panicula densa floribus conglomeratis"), the latter a lax panicle and open corymbs ("panicula laxa corymbosis distantibus"). Both varieties were recognized by TORREY and GRAY (31). Whether these varieties are merely individual variations, denoting early and late stages of growth, or specific distinctions can not be determined; that remains to be learned in the field. An eastern form described by $D_{R}$. FERNALD (8) as S. pennsylvanica L. forma fultior, with large "dilated oval" bracts is of the type possessing a stout contracted or conglomerate inflorescence, a form which reappears in western parts of the range. What aspect this plant assumes at maturity is not known, but the writer is of the opinion, based on a careful study of the carpels and the gland, that it is probably a distinct species. The problem of species in this connection must therefore be left to future investigations (Plate XII).

\section{Saxifraga purpuripetala sp. nov.}

Receptaculum ovario infra medium adnatum; carpidia inferne distenta superne valde contracta stylis conicis conniventibus stigmatibus parvis; folliculi infra medium inflata stylis divergentibus vel recurvatis; glandula lata elevata convulata vel verrucosa; filamenta subulata angustata viridia vel purpurescentia; sepala 2-4 mm. longa cuneata vel deltoidea reflexa base 
coalita viridia vel purpurea; petala $3-4 \mathrm{~mm}$. longa purpurea lanceolata saepe perangustata; semina crassa ovata $1-1.3 \mathrm{~mm}$. longa angulata carinata conspicue longitudinaliter tuberculata.

Receptacle united to the ovary below the middle; carpels distended below, strongly contracted above; styles conical, connivent; stigmas small; follicles inflated below the middle, styles divergent or recurved; gland broad, elevated, convoluted or verrucose; filaments subulate, narrow, green, or purple; sepals $2-4 \mathrm{~mm}$. long, cuneate or deltoid, reflexed, united at the base, green or purple; petals $3-4 \mathrm{~mm}$. long, purple, lanceolate, often very narrow; seeds thick, ovoid, 1-1.3 mm., angled, carinate, prominently, longitudinally tuberculate.

Leaves oblong, elliptic or elliptic-lanceolate, $5-20 \mathrm{~cm}$., dull green to brownish green above, paler yellowish-tinged beneath, glabrous, thin, laevigate, obscurely or shallowly denticulate, tapering to short, broad, membranous-margined, sheathing petiole-like bases. Scapes $45 \mathrm{~cm}$. tall or less, at first stout, later more slender, sometimes branching from below, densely glandular-pubescent, the glands purple, thinner below but hairs longer, whitish and mostly not gland-bearing. Inflorescence paniculate-cymose, elongate, rather compact at first, opening with age, the branches ascending, the upper much shortened. Bracts narrow lanceolate, the lower sometimes foliaceous. Haris uniseriate, of various lengths; glands oblong. Perennial from a stout, woody caudex.

This new species has been long regarded as a purple-flowered form of S. pennsylvanica L. but the color of the petals, the peculiarities of the carpels, gland, seeds, and habit are sufficiently distinct, it seems, to warrant specific rank (Plate XII).

Distribution.-Known only from two localities.

Specimens examined:

Vermont: Peacham. June 13, 1894, Ferdinand Blanchard (MBG 751771, June 3, 1883, MBG 751772, August, 1892, MBG 751775).

New Jersey: near Peapack, ex herbarium, R. C. Perry (MBG 84563).

Saxifraga Sierrae (Coville) Small, Bull. Torr. Bot. Club $23: 362$. 1896.

Saxifraga integrifolia Sierrae Coville, Proc. Biol. Soc., Wash. 7:78. 1892.

Micranthes Sierrae (Coville) Heller, Muhlenbergia 2:52. 1905.

Micranthes arnoglossa Small, N. Am. Fl. 22:2:138. 1905.

"Blades of the larger leaves 8-12 cm. long, oblong-lanceolate to elliptical-lanceolate, conspicuously serrate-denticulate, from glabrous to sparingly clammy-hairy above and beneath, thinner and more distinctly veined than in the type; petiole and margin of the leaf toward the base ciliate with clammy hairs; otherwise as the type form." 
The above description is borrowed from the original of Coville (2) who described the plant as a variety of Saxifraga integrifolia Hook. The type specimen, which has not been available for study, is in the United States National Herbarium. "No. 1705, Death Valley Expedition, Collected August 25, 1891, about eight miles northwest of Whitney Meadows on the Headwaters of Kern River, Sierra Nevada, Tulare County, California, by Frederick V. Coville." Coville states that the plant is found in the Rocky Mountains also. Collections from various localities show several distinct forms referred to $S$. Sierrae of which only those are here given recognition which conform most closely to the descriptions of CoviLLE. The others constitute such a confusing array of forms that the problem of their status must await further study. In addition all Rocky Mountain specimens referred to Micranthes arnoglossa Small are included here.

Specimens examined:

California: Tulare County, summer, 1904, C. F. Baker, No. 4428, collector, J. D. Culbertson, det. by Dr. Greene as Saxifraga oregana Howell (MBG 84087); Coyote Creek, Tulare County, July 20, 1904, C. F. Baker, No. 3265, collector, J. D. Culbertson, det. by Dr. Greene as Saxifraga oregana Howell. (MBG 84085); Sisson, Siskiyou County, June 15, 1905, A. A. Heller, No. 8031 (MBG 84091) as Micranthes Sierrae (Coville) Heller.

Colorado: Marshall Pass, alt. 10,000 ft., July 19, 1901, C. F. Baker, No. 509 (UMH). This specimen cited as the "type collection" of $S$. arnoglossa Greene n. sp.

Saxifraga winnebagoenis sp. nov.

Receptaculum ovario non alte adnatum; folliculi praeparvi globosi superne multo contracti stylis brevissimis stigmatibus parvis; filamenta subulata gracilia brevia; sepala parva oblonga vel ovata vel deltoidea acuta base evidente coalita reflexa; petala non adsunt; semina ovata longitudinaliter tuberculata.

Receptacle shallow; follicles very small, globose, slightly spreading, abruptly contracted above into very short beaks; stigmas small. Filaments subulate, slender, $1.7 \mathrm{~mm}$., exceeding the sepals. Sepals 1.3-1.5 mm., oblong or ovate to triangular, acute, plainly united at base, green, reflexed; lateral nerves 2 , reaching to the middle. Petals wanting in specimens. Seeds about $1 \mathrm{~mm}$., broadly ovoid-fusiform, carinate, with longitudinal ridges of short tuberculate teeth. Hairs of various lengths, uniseriate; glands oblong, sometimes broadest at top, consisting of a row of superposed cells. Leaves 12 $\mathrm{cm}$. long and less, few, elliptic-lanceolate or obovate, minutely denticulate to subentire, shallowly or inconspicuously repand, obtuse to acute, strigillose pubescent on both sides, somewhat leathery, gradually contracted into short, sheathing bases. Scape erect, solitary, about $35 \mathrm{~cm}$., yellowish-green, loosely glandular-pubescent, branching above. Inflorescence racemose-cymose, narrow; cymules contracted at the ends of the branches of the inflorescence. Perennial from a short, stout, coarsely rooted caudex (Plate XIII). 
This plant is very different from the eastern S. pennsylvanica. The unusually small follicles and the rather leathery, yellowish-tinged leaves which are velvety in appearance are the most distinctive characters. In many respects it is very similar to some Rocky Mountain specimens from the United States National Herbarium which ENGLER and Irmscher (7) have referred to $S$. montanensis Small. Spanish Basin, Gallatin County, Montana. Rydberg and Bessey No. 4263 (USNH 360877); Bozeman, Montana, Blankinship, No. 521 (MBG 84116).

Distribution.-Known only from the type locality.

Specimens examined:

Minnesota: Winnebago Valley, Houston County, June 12, 1899, W. A. Wheeler, No. 180 (UMH) Type!

Section Tricarpum, sect. nov.

Micranthes, Small, Fl. S.E.U.S. 501. 1903, as genus; in part.

Boraphila, Rosendahl, Beibl. Bot. Jahrb., Nr. 83 :70. 1905; in part.

Receptacle deeply adnate to the ovary; carpels three, distinct, connected by the receptacle and above by the gland; follicles stout, inflated; styles stout, divergent, rigid; stigmas discoid; gland thick, slightly elevated above the base of the calyx.

Monotypic, including the species described below.

The carpels of this section are generally three together, although four are sometimes present. The receptacle attains a considerable depth, enclosing the carpels for half their length, in this respect resembling the section Chionophila, and Micranthes in part. The beaks are peculiarly rigid and conical, or somewhat pyramidal, and frequently widely spreading. The stigmas are considerably flattened and sometimes incompletely two-lobed. The gland is not elevated to such an extent as in Micranthes, but as in that section the lower margin persists as a distinct flange around the follicles. The follicles remain connected by the receptacle and the gland, even almost to the base of the styles, but are otherwise distinct to the base, although they appear to be united entirely (Plates II, III, XVIII).

The single species of which the section is composed is distributed over a rather limited region from southwestern Missouri to the vicinity of Dallas, Texas. Collectors have described it as a plant of sandy or cherty soils. Its range follows the southwestern extension of the Ozark vegetation belt and flanks the Atlantic forest zone, according to HARSHBERgER (15).

Saxifraga texana Buckl., Proc. Phil. Acad. 1861 :455. 1862.

Micranthes texana (Buckl.) Small. Fl. S.E.U.S. 501. 1903.

Carpels 3 , occasionally 4 ; at maturity stout, pyramidal, contracted above into stout conical, spreading beaks. Stigmas small, flattened or discoid. 
Gland a fleshy, more or less verrucose or convoluted, flattened disc, its lower margin persisting as a thin flange around each follicle, and slightly elevated above the base of the calyx. Filaments subulate, flattened, uncinate; anthers oblong, somewhat contracted above, the margins at length purple. Sepals mostly broad, oblong to triangular-ovate, $1.5-2.5 \mathrm{~mm}$., obtuse to rounded and sometimes retuse at the apex, slightly united at the base; lateral nerves usually 2 , variously branched, sometimes coalescing with the mid-nerve below the apex; entire, glabrous, sometimes irregularly denticulate, spreading. Petals $2.4 \mathrm{~mm}$., white, broadly orbicular or ovate, to spatulate or elliptic-lanceolate; base broad, clawlike in orbicular forms; mid-nerve with 2-4 branches which are often variously forked and coalescent. Leaves basal, small, glabrous ovate to elliptic-lanceolate, $6 \mathrm{~cm}$. long or less, abruptly to gradually contracted into a narrow, flattened, petiole-like base mostly shorter than the blade; margins of blades sinuate to shallowly crenatedentate, ciliolate or eciliolate. Scapes $7-20 \mathrm{~cm}$. high, slender to stout, solitary or several together, rather sparsely glandular-pubescent, the hairs commonly elongated, uniseriate. Inflorescence contracted, paniculate-cymose or merely cymose, sometimes capitate, the cymules glomerate; lowest branches usually shorter than the internodes in branched inflorescences. Perennial from a short fibrous-rooted caudex which often produces several short shoots.

The species has sometimes been referred to $S$. virginiensis from which, however, it can easily be distinguished by the carpels and especially by the mature follicles, the number of which is generally three, as noted above. The two species differ also strongly in seed characters (Plate XVIII).

Distribution.-From southwestern Missouri to the region of Dallas in northeastern Texas.

Specimens examined:

MIssourI: Reding's Mill, April 8, 1909, B. F. Bush, No. 5475 (MBG 84597); Reding's Mill, Newton County, local in chert barrens, April 9, 1909, Ernest J. Palmer, No. 1647 (MBG 760519).

Texas: Terrell-Elmo, April 6, 1903, J. Reverchon, No. 3729 (MBG 84557) ; black sandy land, between French Town and Dallas, J. Reverchon, No. 281 (MBG 84556); Brazos County, sandy land, March 10, 1900, N. Ness, No. 1994 (MBG 84554); damp sands, Elmo, April 6, 1903, J. Reverchon, No. 3729 (MBG 84555).

No state cited, February 27, 1878, J. F. Joor (MBG 84552); ex herbarium, J. Reverchon (MBG 84552).

Section Arabisa Tausch, Hort, Canal, Fasc. 1. 1823.

Spatularia, Haworth, Saxifr. Enum. 47. 1821.

Gymnopera, D. Don, Trans. Linn. Soc. 13 :343. 1822; in part.

Arabidia Seringe, DC. Prodr. $4: 40$. 1839; in part.

Hexaphoma, Raf., Fl. Tell. 2:66. 1836.

Hydatica, Neck. Elem. 2 :387. 1790. Small, N. Am. Fl. 22:2:148. 1905.

Boraphila, Engler, Verh. Zool.-Bot. Ver., Wein. $19: 521.1869$; in part. 
Ovary superior; carpels elliptic-oblong or ovoid, united to below the middle; gland a somewhat constricted, yellowish to purplish girdle above the base of the carpels; follicles ovoid, constricted more or less at the base, the sides marked with more or less prominent longitudinal lines or ribs; strongly contracted above into slender divergent beaks. Stigmas small, globose. Filaments subulate. Sepals oblong, lanceolate-oblong, to ovatelanceolate, acute to obtuse, becoming strongly reflexed. Corolla irregular, white, or yellowish-tinged; upper three petals sagittate, the two lower oblanceolate or merely lanceolate. Seeds elliptic-fusiform, carinate, marked with deeply pectinate, longitudinal ridges. Hairs multiseriate, with globose, multicellular glands. Leaves basal, rosulate, alternate, with elliptic to oblanceolate, deeply and coarsely to shallowly dentate blades, contracted below into broad and flat to slender, petiole-like bases. Scapes solitary or tufted, stout to slender, erect or assurgent, more or less branched above or from near the base, in some forms prolifically, mostly coarsely glandular pubescent. Inflorescence paniculate or paniculate-cymose, often diffuse, with few to numerous flowers, these in the western species replaced to a greater or less degree with bulbils. Perennial herbs from short, slender, fibrous-rooted caudices.

The species comprising this section form a clearly defined natural group, exhibiting striking similarities in the characters of the floral organs. The similarities in the carpels and capsules are so close that it is difficult to distinguish one species from another on these characters.

One of the marked characteristics of this section is the complete hypogyny. In addition there is a prolific production of bulbils in the western species. Only two of our American species, namely S. leucanthemifolia and $S$. ferruginea, attain any appreciable size, and these two are also very similar in vegetative characters, herbarium collections of the latter having been often referred to the former. Their capsules and seeds can be distinguished with difficulty.

All the species appear to be calciphobe. With the exception of $S$. foliolosa and $S$. ferruginea they do not present contiguous or overlapping ranges but occupy separate belts along the periphery of the continent. $S$. foliolosa is circumpolar in its range, with an isolated island of it on $\mathrm{Mt}$. Katahdin, Maine, the only locality from which it is known south of extreme Arctic America (FERNALD, in Rhodora 2:167). It is probable that it transects the limit of the range of $S$. ferruginea on the Bering Sea coast of Alaska. The most extended range is that of $S$. ferruginea, namely from the coast of Alaska, along Bering Sea, to Montana and Oregon. S. bryophora occupies a limited alpine region of the Sierra Nevada of California, radiating from Lake Tahoe. According to HarsheErger (15) it is unknown from the Cascades. It is no doubt an offshoot of $S$. ferruginea, with which it once 
formed a continuous specific line. S. leucanthemifolia occupies a narrow belt of the higher Appalachians, from Maryland to northeastern Georgia. Only a single American specimen of what is probably Saxifraga stellaris L. has been available for study-a specimen from Labrador. None of the western plants examined can be referred to this species, although a specimen from Mt. Hood, Oregon, mentioned later, bears a strong resemblance to it in some vegetative characters (Plates II, XIX).

When HAwORTH (14) in 1821 divided the old Linnean genus Saxifraga he brought together the species $S$. leucanthemifolia Michx., S. Clusii Gouan, and $S$. stellaris L. under the new genus Spatularia. HAworTH clearly diagnosed the characters which define the group. He further divided the genus into two divisions, viz., Verae Rectirostratae, including $S$. leucanthemifolia and S. Clusii; and Spuriae: Curvirostratae, including S. stellaris. The material available is inadequate to verify this distinction. TAuscer and his followers include these species in the section Arabidia, but SERINGE (26) erroneously included $S$. arguta D. Don. LEDEBour (18) failed to. recognize the distinction made by these writers when he combined the sections Arabidia and Micranthes, as did also ENGLER (4) in creating the section Boraphila. SMaLl (27) was the first to recognize the interpretation put upon this group by HAwORTH, when he adopted that author's genus Spatularia.

\section{Section Arabisa}

\section{Key to the SPECIES}

I. Leaves dentate

A. Leaves deeply and coarsely dentate; inflorescence loose....S. leucanthemifolia

B. Leaves more shallowly dentate, mostly towards apex

a. Inflorescence commonly diffuse; some or most of flowers often replaced by bulbils ........................................ ferruginea

b. Inflorescence reduced

1. Flowers, except the terminal, replaced by bulbils; scapes erect, rigid, glabrous; branches of inflorescence short and mostly at right angles with stem ............................................ foliolosa

2. Not bulbil-bearing, flowers conspicuous; scapes pubescent or glabrous........................................... stellaris ${ }^{10}$

II. Leaves entire, small, lanceolate........................... bryophora

Saxifraga bryophora A. Gray, Proc. Am. Acad. 6:533. 1865.

Saxifraga leucanthemifolia Michx. var. integrifolia Engler, Monogr. Saxifr. 135. 1872.

Spatularia bryphora (A. Gray) Small, N. Am. F1. 22:2:148. 1905. (Plate XIX).

\footnotetext{
10 The detailed treatment of this species is deferred for a future paper.
} 
Distribution.-Eastern California in the Sierras, from Fresno County northward to Sierra County, region of Lake Tahoe.

Specimens examined:

CALIFornia: road to Meadow Lake from Webber, Nevada County, grassy slope, August, 1892, Sonne, No. 89 (MBG 83870) ; Placer County, August-October, 1892, A. M. Carpenter (UMH); meadows near Black Mountain, Fresno County, alt. 9,500 ft., July, 1900, Hall and Chandler, No. 595 (UMH, USNH 390665); state survey (5943), Bolander (UMH, USNH 320768) ; 1875, J. G. Lemmon, No. 97 (MBG 84199 and 84200 ) ; Sierra Nevada, peak northeast of Camp 117, alt. 9,000 ft., July 6, 1863, W. H. Brewer, No. 1807 (USNH 320777) ; Kings's Valley, Lassen's Peak, July, i882, Mrs. Austin (USNH 139349); on same sheet, Sierra County, J. G. Lemmon, No. 97 (USNH 139348); Donner Lake, July, 1889, T. S. Brandegee (USNH 735784); ridge south of Donner Pass, alt. 7,500 ft., Nevada County, August 10, 1903, A. A. Heller, No. 7143 (USNH 467528); on dry mountain slope near Webber Lake, alt. 7,000 ft., August 4, 1900, J. B. Leiberg, No. 5260 (USNH 610507); Half Moon Lake, Lake Tahoe region, alt. 7,760 ft., August 9, 1909, E. A. McGregor, No. 73 (USNH 612809); Heather Lake, Lake Tahoe region, August 18, 1909, E. A. McGregor, No. 148 (USNH 612876).

Saxifraga ferruginen Graham, Edinb. New Phil. Jour., p. 348. July, 1828.

Saxifraga notkana Moc., ic. ined., Seringe, DC. Prodr. 4:40. 1830, as synonym.

Hexaphoma ferruginea Raf., Fl. Tell. 2:66. 1836.

Saxifraga Bongardi Presl., ex Engler, Monogr. Saxifr. 135, 1872, as synonym of Saxifraga leucanthemifolia var. Brunoniana (Bong.) Engler.

Saxifraga leucanthemifolia var. Brunoniana (Bong.) Engler, Monogr. Saxifr. 135, 1872.

Saxifraga stellaris Brunoniana Bong., Mem. Acad. St. Petersb. 6:2:140. 1832. (Unverified.)

Saxifraga nootkana Moc., ex Rosendahl, Beibl. Bot. Jahrb., Nr. 84, p. 65. 1905.

Spatularia ferruginea (Graham) Small, N. Am. Fl., 22:2:150. 1905.

Spatularia Vreelandii Small, N. Am. F1., 22:2:149. 1905.

Spatularia Brunoniana Small, N. Am. Fl. 22:2:149. 1905.

Spatularia Newcombei Small, N. Am. Fl. 22:2:149. 1905.

Follicles elliptic-ovoid, united below the middle, contracted above into short slender beaks; stigmas small, globose; sides of follicles marked with more or less conspicuous lines or ribs; carpels ovoid. Gland a fleshy narrow girdle above the base of the carpels. Filaments subulate, flattened, rigid, dilated to adnate at the base; anthers oblong, yellowish to purple. Sepals oblong, oblong-ovate, elliptic-oblong, 2-4 mm., reflexed, acute to obtuse, sometimes ciliolate; lateral nerves commonly 2 , free, mostly simple, reaching beyond the middle and sometimes uniting with the mid-nerve at the apex. Petals 3-7 mm., the upper three more or less sharply sagittate to unequally 
or scarcely at all so, commonly with two yellowish spots below the middle; the two lower oblanceolate to elliptic-lanceolate or ovate; all contracted at the base into conspicuous, mostly narrow claws. Hairs generally elongate; glands globose, whitish to purple. Leaves basal, crowded, $1.5-10 \mathrm{~cm}$., long, oblanceolate to spatulate or cuneate, more or less pubescent, sometimes copiously so-to glabrous or nearly so; more or less coarsely serratedentate above the middle, or incised-toothed, especially towards the apex and above the middle, or remotely serrate-dentate, the teeth elongate, narrow; margins ciliate. Scapes $3-4.5 \mathrm{~cm}$. high, solitary or clustered, erect or assurgent, more or less glandular pubescent, branching at the top or from near the base, often profusely; branches ascending or spreading. Inflorescence paniculate-cymose, the flowers few to numerous, sometimes all but the terminal replaced by bulbils. Bracts lanceolate to oblanceolate, the upper small, the lower foliaceous with a few to several coarse apical teeth; leaflike in some forms.

A polymorphic species of wide range displaying considerable variation in vegetative characters. The different forms, however, do not appear to be of sufficient stability to warrant according them specific rank (Plate XIX).

Distribution.-Islands of Bering Sea, and Alaska to Montana, Idaho, and Oregon.

Specimens examined:

AlASKA: summit of high mountains near Yes Bay, August 21, 1890, Thomas Howell, No. 1621 (UMH); Windham Bay, June 11, 1905, J. D. Culbertson; Kodiak, July 3, 1898, Wm. Trelease, Harriman Alaska expedition.

British Columbia: Nanaimo, Vancouver Island, June 4, 1889, John Macoun (USNH 219860); Moresby Island, July 9, 1900, Wilfred H. Osgood (USNH 620999); Glacier, alt. 5,800 ft., July 20, 1901, C. O. Rosendahl, No. 139 (UMH); Avalanche Mountain, Glacier, August 21, 1902, C. O. Rosendahl, No. 968 (UMH) ; Asulkan Pass, alt. 8,000 ft., August 17, 1904, F. H. Walker, No. 493 (UMH); woods above Revelstoke, alt. 4,000 ft., July 10, 1905, Chas. H. Share, No. 897 (UMH); Cowichan-Alberni Trail, summit of pass, Vancouver Island, alt. 3,000 ft., June 27, 1906, C. O. Rosendahl, No. 1735 (UMH); along the trail above Alberni, Vancouver Island, June 30, 1906, C. O. Rosendahl et al., No. 1623 (UMH); summit of Mt. Edinburgh, Vancouver Island, July 30, 1906, C. O. Rosendahl, No. 1735 (UMH); Fish Creek Valley, alt. 5,500 ft., August, 1906, F. K. Butters and E.W. D. Holway, No. 240; Mt. Edinburgh, Vancouver Island, alt. 2,000 ft., June 7, 1907, C. O. Rosendahl and F. K. Butters (UMH) ; rocky ledge, Cowichan Lake, Vancouver Island, June 15, 1907, C. O. Rosethdahl, No. 1809 (UMH) ; Glacier, alt. 4,100 ft., July 28, 1907, F. K. Butters and E. W. D. Holzeay (UMH) ; snow sheds, Glacier, alt. 4,200 ft., August 24, 1907, F. K. Butters and E.W. D. Holway (UMH); Mt. Abbott, Glacier, alt. 7,000 ft., July 22, 1908, F. K. Butters and E.W. D. Holway (UMH); Glacier, H.C. Cowles, No. 167 (MBG 744924); Queen Charlotte Islands (MBG 71701), as S. Newcombei; Selkirks, C. H. Shaw, No. 451 .

Washington: Skagit Pass, Cascade Mountains, August 24, 1892, Lake and Hull, No. 468 (UMH) ; Stevens Pass, alt. 4,000-6,000 ft., August, 1893, J. H. Sandberg and J. B. Leiberg, No. 1836 (UMH); dry rocky places, Goat Mountains, July 12, 1895 , 
O. D. Allen, No. 199 (UMH) ; along rivulets, Mt. Ranier, alt. 6,500 ft., August, 1895, C. V. Piper, No. 2026 (UMH); north fork of Bridge Creek, Okanogan County, alt. $5,000 \mathrm{ft}$., September, 1897, A. D. E. Elmer, No. 691 (UMH); Olympic Mountains, Clallam County, August, 1900, A. D. E. Elmer, No. 2644 (UMH).

Montana: Sperry Glacier, Marcus E. Jones (UMH); mountain sides, Sperry Glacier, September 1, 1903, L. M. Umbach, No. 812 (USNH 542027); Sperry Glacier, upper temperate life zone, alt. 7,500 ft., Marcus E. Jones, Herbarium of the University of Montana.

Collections of this plant were by some earlier writers referred to S. leucanthemijolia of the Appalachians, which is, however, distinct. Herbarium specimens referred to Saxifraga Bongardi Presl. "in herb. Engler," are all S. ferruginea. Engler (5) gives S. Bongardi Presl., S. notkana Moc. ic. ined., and $S$. stellaris var. Brunoniana Bong. as synonyms of his $S$. leucanthemifolia var. Brunoniana (Bong.) ic. ined. t. 422? ("in America bor. occid. prope Notka.") as a synonym of his S. stellaris var. vulgaris (Ser. MSS.). Rosendahl (25), referring to Seringe, accepts Mocin's Saxifraga notkana as a distinct species apart from $S$. ferruginea, with a slight modification of the orthography. As synonyms ROSENDAHL adjoins S. stellaris var. Brunoniana Bong., S. Bongardi Presl., and S. leucanthemifolia var. Brunoniana (Bong.) Engler. Contemporaneously with RosendaHL, Small, in North American Flora $22: 2: 149$, published two new species, under the genus Spatularia Haw., namely Spatularia Nerucombei, the former based on a collection by F. K. Vreeland 1048, from Glacier Basin, Montana, and the latter on a collection from Queen Charlotte Islands (Torreya 2:55. 1902). The range of the former, to quote SMALL, extends from "British Columbia to Montana and Colorado." That of the latter is limited to "Queen Charlotte Islands, British America." At the same time Small recognizes Saxifraga stellaris Brunoniana Bong. as a distinct species under the name Spatularia Brunoniana (Bong.) Small, citing in addition as synonyms Saxifraga leucanthemifolia Brunoniana Engler (!), Saxifraga notkana Moc., and Saxifraga Bongardi Presl. Smal. also recognizes as distinct Saxifraga ferruginea of Graham, under the name Spatularia ferruginea (Graham) Small, giving its distribution as "Alaska to British Columbia," and adjoining as a synonym Hexaphoma ferruginea Raf. Fl. Tell. 2:66. 1836. Small's descriptions of these four species fail to show any sound and stable characters by which they may be recognized, and the single characters, made use of in his key to separate the species, are fluctuating and unreliable. Spatularia Vreelandii and $S$. Brunoniana, for example, (along with S. bryophora and $S$. foliolosa) are distinguished from $S$. Newcombei, and $S$. ferruginea (along with $S$. stellaris and $S$. petiolaris ( $S$. leucanthemifolia)) by the fact that their inflorescences are bulblet-bearing, the inflorescences of the latter being without bulblets. Further fine distinctions are made in regard to the relative number of flowers and bulblets in distinguishing S. Brunoniana 
from S. Vreelandii and in distinguishing S. Newcombei from S. ferruginea by the relative length of their petals in millimetric denominations. While, as pointed out above, several forms are indicated as occurring in, and limited to, certain regions of the entire range of our species, they can not be separated on the characters mentioned in the preceding lines. With large collections from several herbaria before me, covering the entire range of the above-named species, it appears, if the collections are grouped according to localities, that the bulblet-bearing character is common to all, and that such great fluctuations in the form and size of the petals occur, even in specimens from the same collection and on the same sheet, as to make valueless any specific distinctions on these grounds. Small's species Spatularia Newcombei, of which a photograph only is available (MBG 717014), and which, according to SMALL, is known only from the type locality (Queen Charlotte Islands) has its homotype in Cowles' 167, from Glacier, British Columbia (MBG 744924), and in MacDougal's 384, from Kootenai County, Idaho (UMH) ; except for the few bulblets on the last named, it is, in leaf character and pubescence, indistinguishable from Spatularia Nerecombei. The same applies to No. 451, Shaw's Selkirk flora. Small's Spatularia Vreelandii is merely a small statured form of the plant, homotypes of which occur in collections from all parts of the entire range. On sheet No. 422334 USNH, collected by Culbertson at Windham Bay, Alaska (Baker 4921), for instance, are two plants, one large and leafybracted, with numerous large flowers and no bulblets and strikingly similar in floral characteristics to SmaLL's S. Newcombei; the other small, $(12 \mathrm{~cm}$. high) with all but the terminal flowers replaced by bracts, and corresponding in every way with S'MALI's description of $S$. Vreelandii. In fact the several forms which have been described as species occur together constantly throughout the entire range, often appearing together in collections from various herbaria, on the same sheet. A good comparison of coast and inland forms is found in Rosendahl's No. 1809, from Cowichan Lake, Vancouver Island, which is exactly similar to a specimen collected by Marcus E. Jones at Sperry Glacier, Montana, at least in foliage characters. According to DR. F. K. Butrers, who has made a thorough and comprehensive study of the Selkirk flora, both bulblet-bearing and non-bulblet-bearing forms may be found repeatedly growing together, and he has observed that the bulblet-bearing habit is commonly associated with altitude. Seeds of the Selkirk plants planted by Dr. Butrers in the greenhouse of the University of Minnesota developed into plants which ran to bulblets entirely. Plants collected by Butters and Rosendahl on the snowshed at Glacier, British Columbia, differ markedly from others of the same locality in being tall, excessively tufted, and profusely branched, with an abundance of flowers, fruit, and glabrous leaves. 
A study of a great deal of material at hand has failed to disclose any appreciable differences in the characters of those organs which are usually regarded as showing the greatest constancy, namely fruit and seed. For this reason all the various segregates which have been made are herein regarded as one species. And the specific name ferruginea of Graham is adopted, since it antedates others. The specific name Brunoniana, as used by some writers, appears invalid, having a previous application to a species of the section Trachyphyllum.

Those forms which exhibit constant peculiarities of form and habit, correlated with a continuous range over a particular region, may be regarded as varieties, and, as regards our species, at least two such varieties occur continuously at the northern and the southern extremes of the range, with a probable third in Washington and Oregon in the southern extreme. More extensive collections and a more careful survey of the particular regions are to be desired. A description of the varieties together with their ranges follows:

Var. foliacea var. nov. Scapus aut solitarius aut caespitosus tenuis ample ramosus grosse atque laxe glanduloso-pubescens ad medium bracteas foliaceas gerens, foliis magnis ad basim cuneatis grosse serrato-dentatis.

Scapes solitary or tufted, erect or assurgent, commonly weak, coarsely and loosely glandular-pubescent, often prolifically branched, with large leafy bracts to above the middle, and numerous bulblets and flowers, the flowers usually terminal. Leaves large, thin, broadly oblanceolate-elliptic, rounded at the apex, coarsely serrate-dentate, the teeth few, cuneately narrowed below into a broad or narrow base; glabrous or sparingly pubescent, conspicuously ciliate on the margins. The large leafy bracts and weak habit of the plant are characteristic.

Distribution.-High mountains of Kootenai County, and probably also Soshone County, Idaho.

Specimens examined:

Idaho: Palouse County and Lake Coeur d'Alene, August, 1892, J. H. Sandberg (UMH) ; Packsaddle Mountain, Kootenai County, August 10, 1892, D. T. MacDougal, No. 384, (UMH) ; crevices of ledges of porphyritic granite of Packsaddle Mountain, alt. 8,000 ft., Lake Pend d'Oreille, July 12, 1889, J. B. Leiberg, No. 468 (UMH, MBG 84379); Lake Pend d'Oreille, alt. 3,000 ft., August, 1892, D. T. MacDougal (UMH); Kootenai County, High Mountains, July, 1892, J. H. Sandberg (UMH); crevices of rocks, summit of Packsaddle Peak, Kootenai County, August 5, 1892, Sandberg, MacDougal, and Heller, No. 834.

Var. grandiflora var. nov. Foliis ad $6 \mathrm{~cm}$. longis ad basim cuneatocontractis, floribus majoribus nonnumquam numerosis, bulbillis paucis, inflorescentiae ramis diffusis.

Flowers unusually large, sometimes numerous; bulblets few. Scapes rather stout, solitary or several together, coarsely and loosely pubescent, 
branching above the middle, the branches spreading; leaves thin, oblanceolate-elliptic, glabrous or scantily pubescent, coarsely serrate-dentate above the middle, cuneately contracted below into a broad or narrow base, $6 \mathrm{~cm}$. and less.

Distribution.-Alaska westward to Kodiak Island.

Specimens examined:

AlAska: Windham Bay, June 11, 1905, C. F. Baker, No. 4921, J. D. Culbertson (USNH 422334) Type; on rocky bluffs, shores of Behm Canal, 1894, M. W. Gormas (UMH) ; Kodiak, July 3, 1899, Wm. Trelease, No. 4046 (MBG 84045).

Also the following peculiar form based on a single specimen:

Var. cuneata var. nov. Scapus $17 \mathrm{~cm}$. altus, foliis ad basim latam cuneato-contractis grosse serrato-dentatis, inflorescentiae ramis flores magnos paucos atque bulbillos paucos gerentibus, fructibus crassis.

Leaves with elongated broad, flat, cuneate bases, slightly expanded above into a short coarsely serrate-dentate, few-toothed blade; pale green, thinly pubescent, margins ciliate, apex acute. Scape about $17 \mathrm{~cm}$. high, stout, branching into a few-flowered stout cymose inflorescence at the top. Bulblets very few, flowers large, fruit stout, brownish. Filaments stout, rigid, light-colored against the brown follicles.

Specimens examined:

Moresby Island, Queen Charlotte Islands, July 2, 1900,W. H. Osgood (USNH 620099).

The following specimens are characterized by possessing elongated narrow leaves and a loose spreading inflorescence of slender branches.

Var. diffusa var. nov. Scapus $15-22 \mathrm{~cm}$. altus, laxe pubescens supra medium paniculato-cymose diffuse ramosus, foliis ad $9 \mathrm{~cm}$. longis glabris oblanceolatis grosse serrato-dentatis, floribus magnis, bulbillis paucis vel nullis.

Leaves $9 \mathrm{~cm}$. and less, narrow, glabrous, oblanceolate, acute, coarsely serrate-dentate, the teeth few and remote, scapes $15-22 \mathrm{~cm}$., solitary or several together, assurgent, sparsely pubescent, diffusely branched above the middle or from below the middle, the branches slender, spreading. Inflorescence paniculate-cymose, open. Flowers rather few, large, with or without bulblets.

Specimens examined:

Alaska : summit of high mountains near Yes Bay, August 21, 1895, Thos. Howell, No. 1621 (UMH, MBG 84021).

The Minnesota sheet contains one small specimen, among two others, which has small leaves of the usual ferruginea type. One of the specimens, from the Missouri Botanical Gardens, possesses what appears to be bulblets. 
The following collections from Mt. Hood and Mt. Adams approach Saxifraga stellaris in their leaf characters:

Var. stellariformis var. nov.. Caulescens, scapo tenui, inflorescentiae ramis filiformibus flores paucos atque bulbillos gerentibus, foliis grosse paucidentatis sparsim pubescentibus ad basim attenuate contractis.

Thomas Howell, Mt. Hood, Oregon, August, 1881 (UMH) ; caulescent. scapes slender, branches of inflorescence filiform, few-flowered, producing flowers and bulblets. Leaves broad in proportion to length, thin, coarsely few-toothed, or with a few apical teeth, sparsely pubescent, cuneately contracted below into slender petiole-like bases, mostly equalling or exceeding the blades.

Howell's specimen is the nearest approach to S. stellaris of any plant found in the western material examined, except for the form of the scape, which appears to be typical ferruginea. A more extensive collection is needed here.

Var. nivea var. nov. Scapus 5-10 cm. longus crassus, inflorescentia flores magnos atque bulbillos gerens, foliis ad 1.5 longis ad scaporum basis dense aggregatis apice grosse 2-4-dentatis glabris vel sparsim pubescentibus.

Snow-line, Mt. Adams, warm, moist, sandy slopes, August 10, 1882, L. F. Henderson, No. 288, as S. stellaris (MBG 84387); scapes short. stoutish, 5-10 cm., inflorescence bulblet and flower-bearing, the flowers large in proportion to the size of the plants. Leaves short, $1.5 \mathrm{~cm}$. and less, crowded at the base of the scape, thick with 2-4 coarse apical teeth, glabrous in one or two specimens, scantily pubescent in the others. The smaller plants show a strong similarity to other small forms of $S$. fermininea, however.

Saxifraga foliolosa R. Br., Chlor. Melv. 17. 1823.

Saxifraga stellaris comosa Poir. in Lam. Encyc. 6:680. 1804. (Unverified.)

Saxifraga stellaris prolifera Cham., in Lit., ex Engler, Monogr. Saxifr. 133,1872 , as syn.

Saxifraga stellaris foliolosa Turcz., Lac. Baic. 496.

Saxifraga comosa Britton, Mem. Torr. Bot. Club 5:178. 1894.

Spatularia foliolosa (R. Br.) Small, N. Am. Fl. 22:2:158. 1905.

The leaves of the specimens examined are smaller than those of the European specimens of Saxifraga stellaris L. The rigid erect scapes and stiff branches of the inflorescence are quite characteristic of this species. Only a single specimen of those examined possessed a terminal flower (Plate XIX).

Distribution.-According to Small: "Circumboreal, southward to the mountains of Maine; also in Europe and Asia." (l.c.). According to Engler l.c.: "In der polar rcgion ziemlich verbreitet." 
Specimens examined:

Nugsuak Peninsula: "Collected by the Cornell Party on the Peary Voyage of 1896," August 12 (UMH and MBG 84303).

St. George Island, July 31, 1891, Jas. M. Macoun (MBG 84046).

Saxifraga leucanthemifolia Michx. Fl. Bor. Am. 1:268. 1803.

Spatularia leucanthemifolia Haw., Enum. Saxifr. 48. 1821.

Hexaphoma petiolaris Raf., F1. Tell. 67. 1836.

Saxifraga Michauxii Britton, Mem. Torr. Bot. Club 4:118. 1894.

Spatularia Michauxii (Britton) Snall, F1. S.E. U.S. 502. 1903.

Spatularia petiolaris (Raf.) Small, N. Am. Fl. 22:2:150. 1905.

Distribution.-Mountains, Maryland to Georgia.

Specimens examined:

Tennessee: Cades Coves, eastern Tennessee, August, 1899, F. H. Ferriss (MBC; 83933).

Maryland: June 18, 1899, J. R. Churchill (MBG 738695).

VIRGINIA: plants of Stony Man Mountain and vicinity, Blue Ridge, near Luray, alt. $3.700 \mathrm{ft}$., September 4, 1901, F. S. and Mrs. Stecle, No. 76 (UMH and MBG 83932) ; Bedford County, A. H. Curtiss (MBG 777207); peaks of Otter, Bedford County, July 27, 1871, A. H. Curtiss (MBG 84235); Salt Pond Mountains, Giles County, alt. 4,800 ft., August 19, 1875, John H. Redfield (MBG 83908); A. F. E. Creeson (MBG 84062) ; summit of White Top Mountain, Washington County, August 11-12, 1892, J. K. Small (MBG 83934).

North Carolina: Statesville, M. E. Hyams (UMH); Roan Mountain, A. Ruth, (UMH) ; Roan Mountain, alt. 6,000 ft., July 15, 1880, $/$. W. Chickcring; Grandfather Mountain, Mitchell County, alt. 5,500-6,000 ft., August 25, 1893 (UMH and MBG 83935); "In montibus Carolinae et Georgiae," Buckley (MBG 83911); on rocks, Roan Mountain, a1t. 6,100 ft., July, A. H. Curtiss, No. 854 (UMH) ; Enos Plott, Balsam Mountain, alt. 6,100 ft., August 28, and Roan Mountain, 6,400 ft., September 8, 1876, Redfield, Nos. 5500 and 5561 (MBG 83907); mountains, Leroy, Ruger, and Redfield, No. 2005 (MBG 83906) ; Swain County, "Pinnacle Rock, Clingman's Dome," alt. 6,660 ft., 1891 ; Beardslee and Kofoid (MBG 83910, 83896); Grandfather Mountain, July 22, 1890, A. A. Heller, No. 51 (MBG 83904, UMH) ; Blowing Rock, July 19, 1890 (UMH) ; top of Roan Mountain, September 8, 1876, G. Engelmann (MBG 84236); Cranberry Mountain, journey of September 22, 1898, Sargent, Muir, and Canby, No. 45 (MBG 83901); Grandfather Mountain, Mitchell County, July, 1895, herbarium of Fred. Wislizenus (MBG 84579); Buncombe County, wet rocks near the summit of Craggy Mountain, alt. 6,000 ft., July 8, 1897, Biltmore Herbarium, No. 1231d, (MBG 83898, UMH).

\section{Section Heterisia (Raf.) sect. nov.}

Heterisia Raf., Fl. Tell. $2: 60$. 1836; as genus.

Steiranisia, Raf., F1. Tell. $2: 69$. 1836; as syn.

Hydatica, Torrey and Gray, F1. N. Am. 1:567. 1838-1840; in part. Hooker, Fl. Bor. Am. $1: 252$. 1840 ; in part. Ledebour. Fl. Ross. 2:216. 1844 ; in part.

Boraphila, Engler, Verh. Zool.-Bot. Ver., Wien. 19:522. 1869; in part. 
Ovary free; carpels united to the middle and surrounded by a deep, thick, convoluted gland. Follicles pyriform, inflated below, strongly contracted above into slender, divergent beaks. Filaments clavate. Sepals at length reflexed. Seeds fusiform, faintly striate to smooth, slightly winged by the loose seed-coat. Hairs, multiseriate (Plates II, XII).

Monotypic, comprising the following species:

Saxifraga Mertensiana Bong., Mem. Acad. St. Petersb. VI:2:141. 1832.

Saxifraga heterantha Hook., Fl. Bor. Am. 1:252. 1832.

Steiranisia heterantha Raf., F1. Tell. 2:69. 1836.

Heterisia Mertensiana (Bong.) Small, l.c.

Heterisia Eastwoodiae Small, l.c.

Distribution.-From Sonoma County, California, the Blue Mountains of southeastern Oregon, and the Bitter Root Mountains of Idaho and Montana to the region of Yakutat Bay, Alaska.

Specimens examined:

AtAska: Sitka, June 17, 1899, Wm. Trelease, No. 4063 (MBG 83987); Sitka, June 17, 1899, Wm. Trelease, No. 4063 (MBG 83988); Port Wells, Prince William Sound, June 26, 1899, Wm. Trelease, No. 4064 (MBG 83989); at the base of Mount Tebenkoff, Yakutat Bay, June 22, 1892, Frederick Funston, No. 41 (MBG 83990).

British Columbia: stream sides, Prairie Hills, alt. 5,400 ft., July 26, 1907, Butters and Holway 235 (UMH); Avalanche Crest, Glacier, alt. 6,200 ft., July 28, 1907, Butters and Holway, No. 235 (UMH) ; wet ledges above Cougar Valley, alt. 5,600 ft., July 18, 1908, Butters and Holway (UMH); along banks of streams, Cowichan Alberni Trail, Vancouver Island, alt. 2,600 ft., June 26, 1906, C. O. Rosendahl (UMH); Cameron River Valley, Vancouver Island, June 28, 1907, C. O. Rosendahl, No. 1991 (UMH and MBG 84054); alpine meadow in the Big Bend district, about $118^{\circ} 20^{\circ} \mathrm{W}$. long. $51^{\circ} 45^{\prime}$ N. lat., alt. 7,500 ft., July 26, 1905, H. Shaw, No. 1016 (MBG 83919).

WASHington: north fork of Bridge Creek, Okanogan County, on moist mossy flanks of cliffs, September, 1897, A. D. E. Elmer, No. 716 (UMH); Snoqualmie, June 4, 1889, E. C. Smith (MBG 83918); clefts of rocks, Goat Mountains, alt. 5,500 ft., August 12, 1896, O. D. Allen, No. 241 (MBG 83926); Olympic Mountains, Clallam County, July, 1900, A. D. E. Elmer, No. 2643 (UMH, MBG 83929); mossy rocks at Quiniault Falls, June 21, 1902, H. S. Conard, No. 390 (UMH); Baldy Peak, Chehalis County, alt. 3,500 ft., July 21, 1897, H. Lamb, No. 1348 (MBG 83927).

IDAHo: ledges, Kootenai County, June, 1892, J. B. Leiberg, No. 467 (UMH); divide between St. Joseph and Clearwater River, alt. 1,600 m. July 9, 1895, J. B. Leiberg, No. 1206 (MBG 84081) ; Palouse County and about Lake Coeur d'Alene during June and July, 1892, and May, 1892, J. H. Sandberg (UMH); Nez Perces County, moist hillsides, May, 1892, NSS, No. 3170 (UMH, MBG 83930, 83924); mountain slopes, Kootenai County, July, 1887, J. H. Sandberg (UMH).

OrEGoN : 1871, Hall, No. 152 (MBG 84225); 1871, Hall, No. 152 (MBG 83921) ; wet rocks on the Wallowa Mountains, September 1, 1899, W. C. Cusick, No. 2327 (UMH, MBG 83925); Bingham Springs, western slope of the Blue Mountains, alt. $766 \mathrm{~m}$., June 12, 1908, and 3321, wet granite cliffs, Wallowa Mountains, alt. 3,000 m. August 17, 1908, W. C. Cusick, No. 3330, (MBG 84049) (both on same sheet); 
Oneonta, June, 1886, Thos. Howell (UMH); left fork of Wallowa River, Wallowa Mountains, alt. 6,000 ft., July 12, 1897, E. P. Sheldon, No. 8548 (MBG 84072).

California: Gasquet, April 20, 1892, Thos. Howell, No. 1428 (MBG 83931, UMH) ; Ukiah, 1866, H. N. Bolander, No. 4652 (MBG 84224); Mill Creek, Mendocino County, 1866, H. N. Bolander, No. 4652 (MBG 83928); Emigrant Gap, July 1, 1882, $M$. E. Jones, No. 3588 (MBG 810802) ; along Little River, Humboldt County five miles from the coast, alt. about $400 \mathrm{ft}$., June 4, 1911, P. Tracy, No. 3217 (MBG 84598); woods near Cazadero, Sonoma County, April 24, 1903, A. A. Heller, No. 6616 (MBG 83923).

Montana: Darby, upper temperate life zone, alpine, alt. 7,500 ft., July 30, 1909, M. E. Jones (MBG 84959).

\section{SPECIES INCERTAE SEDIS}

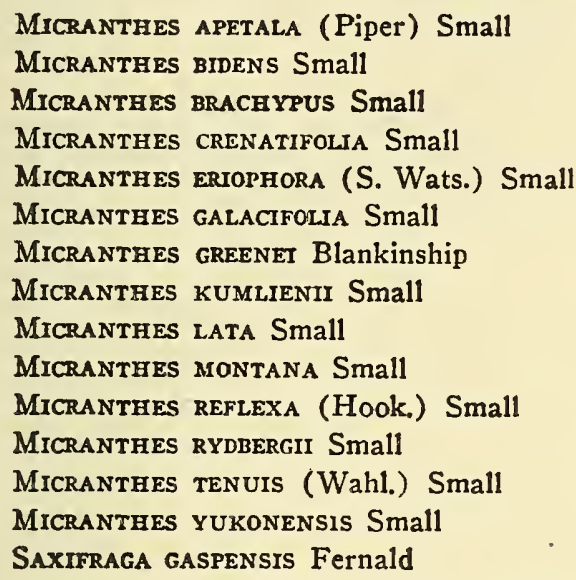

No specimens of the above species have been available for study, and as the descriptions of the authors deal principally with vegetative characters their status can not be definitely determined at this time.

Micranthes eriophora (S. Wats.) Small appears to be very different from any species described in this paper, but the specimen at hand is in such poor condition that no definite conclusions can be drawn from it.

Saxifraga gaspensis Fernald was separated by its author from Saxifraga nivalis. The distinguishing characters as pointed out by FERNALd appear, however, to be wholly vegetative.

Micranthes apetala (Piper) Small is probably a form of Saxifraga nidifica Greene.

This monograph was undertaken at the suggestion of Dr. C. O. Rosendahl, and has been carried out under his direction. The writer was privileged to use the large collection of Saxifragas in the Herbarium of the University of Minnesota, and other large and valuable collections kindly loaned by other herbaria.

The writer desires to express his thanks to Dr. Rosendahl for much needed advice, for his efforts in securing valuable herbarium materials, and providing ample facilities for carrying on the work; to Dr. Frederic K. Butters for much practical advice, helpful criticism, and information about the Saxifraga flora of the Selkirks and the 
Canadian Rocky Mountains; to Dr. William S. Cooper for helpful suggestions touching ecological factors; to Dr. Oscar W. Oestlund for many inspiring ideas and guiding principles drawn from his fund of knowledge of the science and philosophy of taxonomy. Especial thanks are due to Dr. W. R. Maxon, of the United States National Herbarium, for the loan of indispensable herbarium material; likewise to Dr. George T. Moore and Dr. J. M. Greenman for the loan of a large collection from the Herbarium of the Missouri Botanical Garden. The writer wishes also to express his thanks to Dr. H. M. Hall for specimens from the Herbarium of the University of California; to Mr. F. S. Hall for specimens from the Herbarium of the State Museum, University of Washington, Seattle; to Dr. F. L. Pickett, Washington State College, Pullman, Washington, for specimens from that region; to Dr. J. E. Kirkwood, University of Montana, Missoula, Montana, for specimens from the Rocky Mountain region; and to Mr. Alonzo P. Troth, of the Lewis and Clark High School, Spokane, Washington, for fresh material from the Spokane Valley.

Owing to conditions resulting from the World War Engler's monograph on Saxifraga in Das Pflanzenreich (IV:117:I. 1916, IV:117:II. 1919) was not obtainable when this paper was in process of preparation.-AuTHoR.

University of Minnesota, 1919. 


\section{LITERATURE CITED}

1. Britton, N. L. and Brown, A. Illustrated flora of the northern United States, Canada, and the British Possessions. Vol. 2, page 174. 1897.

2. Coville, F. V. Proc. Biol. Soc. Washington $7: 78.1893$.

3. Don, D. Monograph of the genus Saxifraga. Trans. Linn. Soc. 13. 1822.

4. ENCirk, A. Index criticus specierum atque synonymorum generis Saxifraga. Verh. Zool.-Bot. Ver., Wien. Vol. 19. 1869.

5. - - Monographie der Gattung Saxifraga. Breslau. 1872.

6. - Saxifragaceae, in Die Natürlichen Pflanzen Familien 3:2a:41-93. 1891.

7. - and IRMSCHER. Manuscript notes on sheets of the United States National Herbarium.

8. Fernald, M. L. New species, varieties, and forms of Saxifraga. Rhodora 19:141. 1917.

9. Gray, Asa. Nutes on a botanical excursion to the mountains of South Carolina. London Journ. of Bot. $2: 113.1843$.

10. Chloris Boreali Americana. Mem. Am. Acad. 3:39. 1846.

11. Greene, E. L. Novitates Occidentalis. Erythea 1:222. 1893.

12. Godron, D. A. Flore de France. 1848-56.

13. Haworth, A. H. Synopsis plantarum succulentarum. 1812.

14. - Saxifragarum enumeratio. 1821.

15. Harshberger, J. W. Phytogeographic survey of North America. 1911.

16. Hooker, W. J. Flora Boreali-Americana. Vol. 1, pages 242-55. 1840.

17. Howell, Thomas. New species of Pacific Coast plants. Erythea 8. 1895.

18. Ledebour, C. F. Flora Rossica. Vol. 2, pages 204-25. Stuttgart. 1844.

19. Michaux, A. Flora Boreali Americana. Vol. 1, page 269, 1803.

20. Pallas, P. S. Reise durch verschiedene Provinzen Russischen Reich, 3. 1878.

21. Piper, C. V. Flora of Washington, Contrib. U. S. Natl. Herb. 11. 1906.

22. - New and noteworthy northwest plants IV. Bull. Torr. Bot. Club $27: 393.1900$.

23. Pursh, Frederick. Flora Americae Septentrionalis. Vol. 1, page 311. 1814.

24. Rafinesque, C. S. Flora Telluriana 2:68. 1836.

25. RosendahL, C. O. Die nordamerikanischen Saxifraginae u. ihre Verwantschafts Verhältnisse in bez. ihrer geo. Verbreitung. Beibl. Engl. Bot. Jahrb. 83. 1905.

26. Seringe, N. C. Saxifraga in DC. Prod. 4:17-47. 1839.

27. Small, J. K. Saxifragaceae in North American Flora $22: 2: 126-56$.

28. - - Saxifragaceae in Britton and Brown, Illustrated flora. Second edition. Vol. 2, pages 214-30. 1913.

29. - - and Vail, Anna Murray. Report of a botanical exploration of southwestern Virginia. Mem. Torr. Bot. Club 5:118. 1893.

30. TAusch, I. F. Hortus Canalius. fasc. 1. 1823.

31. Torrey and Gray. Flora of North America. Vol. 1, pages 563-76. 1838-1840.

32. Wrlldenow, C. L. I-innaeus Sp. Pl. Fourth edition. Vol. 2, pages 639-58. 1799. 

EXPLANATION OF PLATES 


\section{Plate I}

$A, B$, section Hydatica. $A$, capsule in the subsection Rotundifoliatae; $B$, follicles in the subsection Cuneifoliatae; $a, b$, young stages of $A ; c$, young stages of $B ; g l$, gland; $A, d, e$, types of hairs in the section Hydatica; $C$, follicles of the section Calthophyllum; $f$, young stage of same; gl, gland; $g$, type of hair in Calthophyllum; $D$, capsule of the section Aulaxis; $h$, types of hairs in Aulaxis; $k$, young stage of pistil of Aulaxis; gl, gland; $E$, type of carpels in the section Dermasea; $i, j$, young stages of the same; $g l$, gland; $l$, type of hair in the section Dermasea. 


\section{Phate II}

$F$, follicles of the section Chionopkila; $m$, young stage of same, dorsal aspect; $g l$, gland; $G$, follicles of the section Micranthes; $n$, young stage of same; gl, gland; $f$, flange of the gland; $H$, follicles of the section Tricarpum; 0 , young stage of same; $g l$, gland; $f$, flange of gland; $p, p, p$, types of hairs in sections Chionophila, Micranthes, and Tricarpum; I, capsule of the section Arabisa; s, young stage of same; $g l$, gland; $J$, capsule of the section Heterisia; $r$, young stage of same; $g l$, gland; $q$, type of hair in sections Arabisa and Heterisia. 


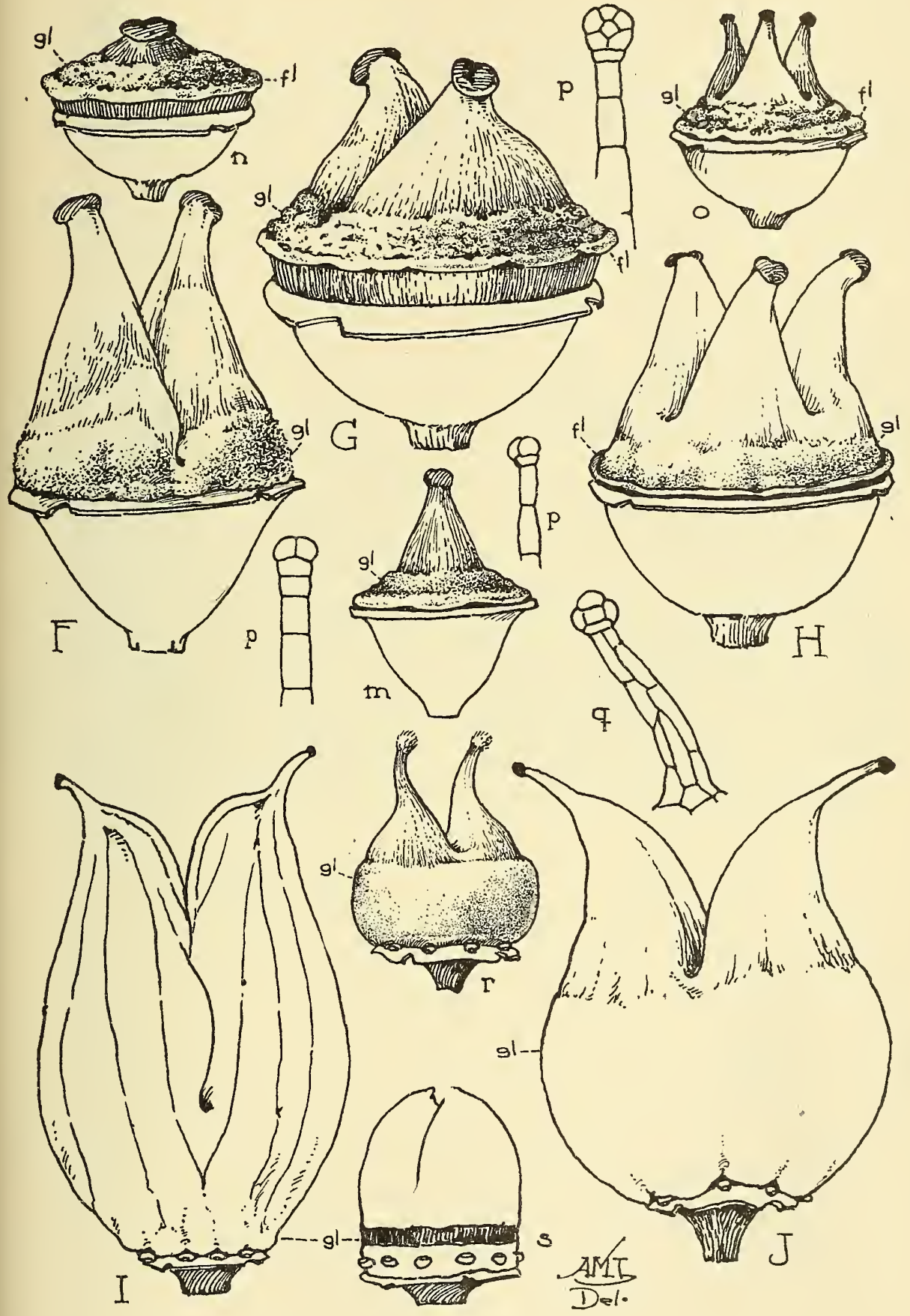

Plate. II 


\section{Plate III}

Ventral aspects of the carpels of the sections in which the receptacle is more or less adnate to the ovary (in all cases the gland is shaded black): section Micranthes: 1, S. californica; 2, S. fragosa; 3, S. pennsyluanica; 4, S. montanensis; 1'-4', carpels of the same seen from above, showing nature of the gland in each; section Chionophila; 5, S. thomboidea; 5', young stage of same seen from above, showing gland; $x$, point of connection of carpels; section Tricarpum: $6, S$. texana; $6^{\prime}$, young stage of same seen from above; $x$, line of connection of carpels (shaded in line); section Dermasea: 7, young stage of carpel of $S$. caroliniana; $8,8^{\prime}$, old and young stages of carpels of S. rufidula; $9,9^{\prime}$, the same of S. occidentalis; 10, carpel of S. idahoensis; 11 , 11', early stages of carpels of $S$. virginiensis. Figures 7 and 11 also show the variations in the depth of the receptacle in species of the section Dermasea. 

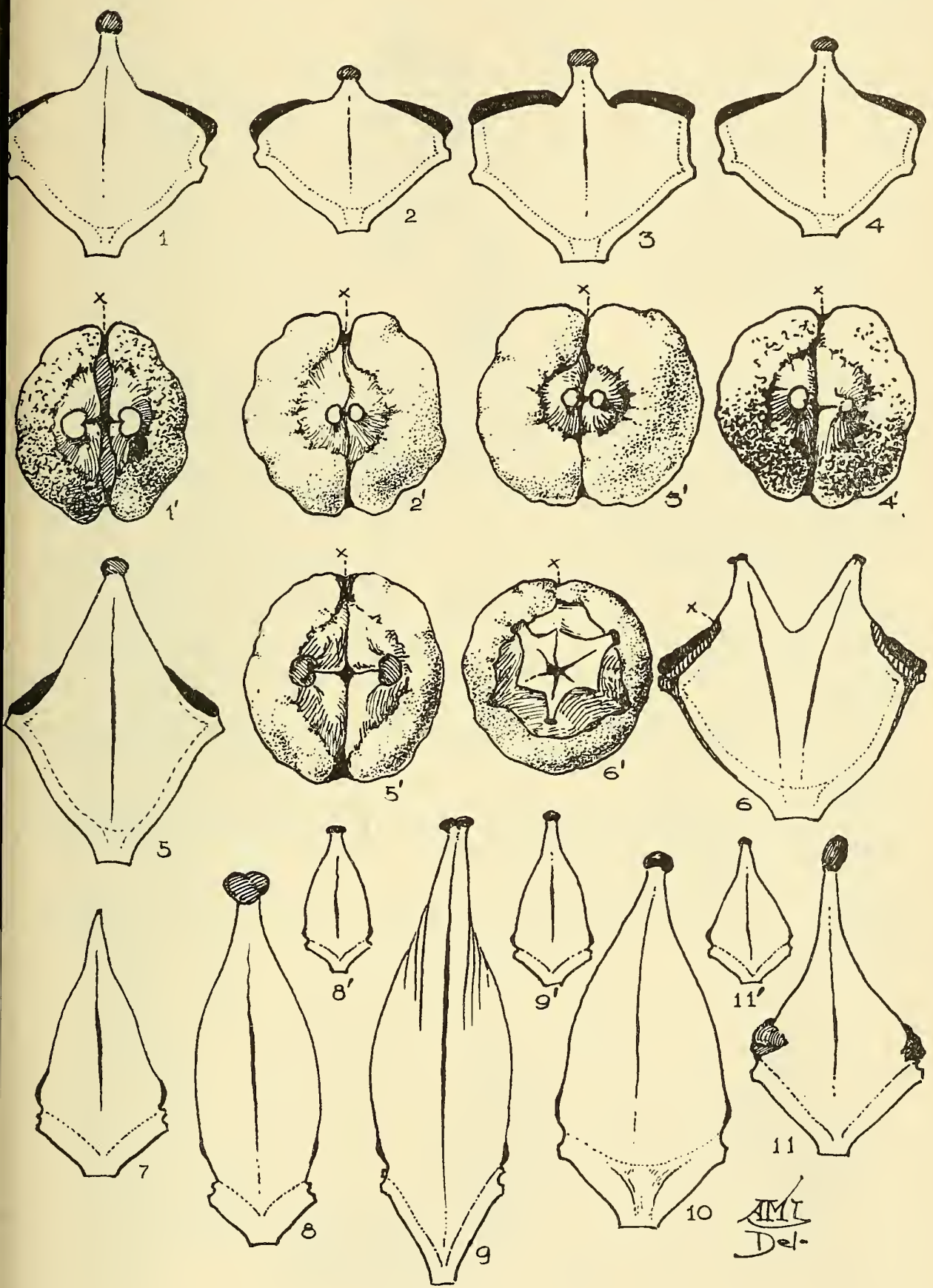

Plate III 
Plate IV*

I. Section Hydatica. capsule of S. arguta; 1, petal; 2, sepal; 3, filament; 4, seed; 5, hair and its gland; 6, leaf; drawn from a specimen collected by S. G. Stokes in the vicinity of Clayton Peak, Wasatch Mountains, Utah (MBG 84500).

II. Immature capsule of $S$. aestivalis; 7 , petal; 8 , sepal; 9, filament; 10 , non-glandbearing hair; 11, seed; gl, gland; 11a, pistil, showing bottle-shaped form of young carpels, typical of the section; drawn from Piper's No. 2622, from Mount Rainier. Washington (UMH).

III. Mature capsule of $S$. Nelsoniana; 12, sepal; 13, glands of hairs; 14, seed; drawn from Jas. M. Macoun's No. 231, from Copper Islands, Bering Sea (USNH 249366).

IV. Mature capsule of $S$. unalaschensis; 15 , filament; 16 , petal; 17 , sepal; 18 , seed: drawn from a specimen collected by Trevor Kincaid on Popoff Island, Alaska (USNH 375422 ).

V. Mature capsule $S$. davurica; 19 , sepal; 20, filament; 21 , leaf; 22, seed; drawn from a specimen collected by Chester Washburn, near Cape Sabine, Alaska (USNH 421209).

VI. Mature capsule of $S$. Lyallii; 23, petal; 24, sepal; 25, filament; 26, hair and gland; 27, seed; drawn from Butters and Holway's No. 818, from the Cougar Valley, Selkirk Mountains, British Columbia (UMH).

"The small numbers associated with figures of organs refer to the length in millimeters, natural size. 
JOHNSON: A REVISION OF THE SECTION BORAPHILA

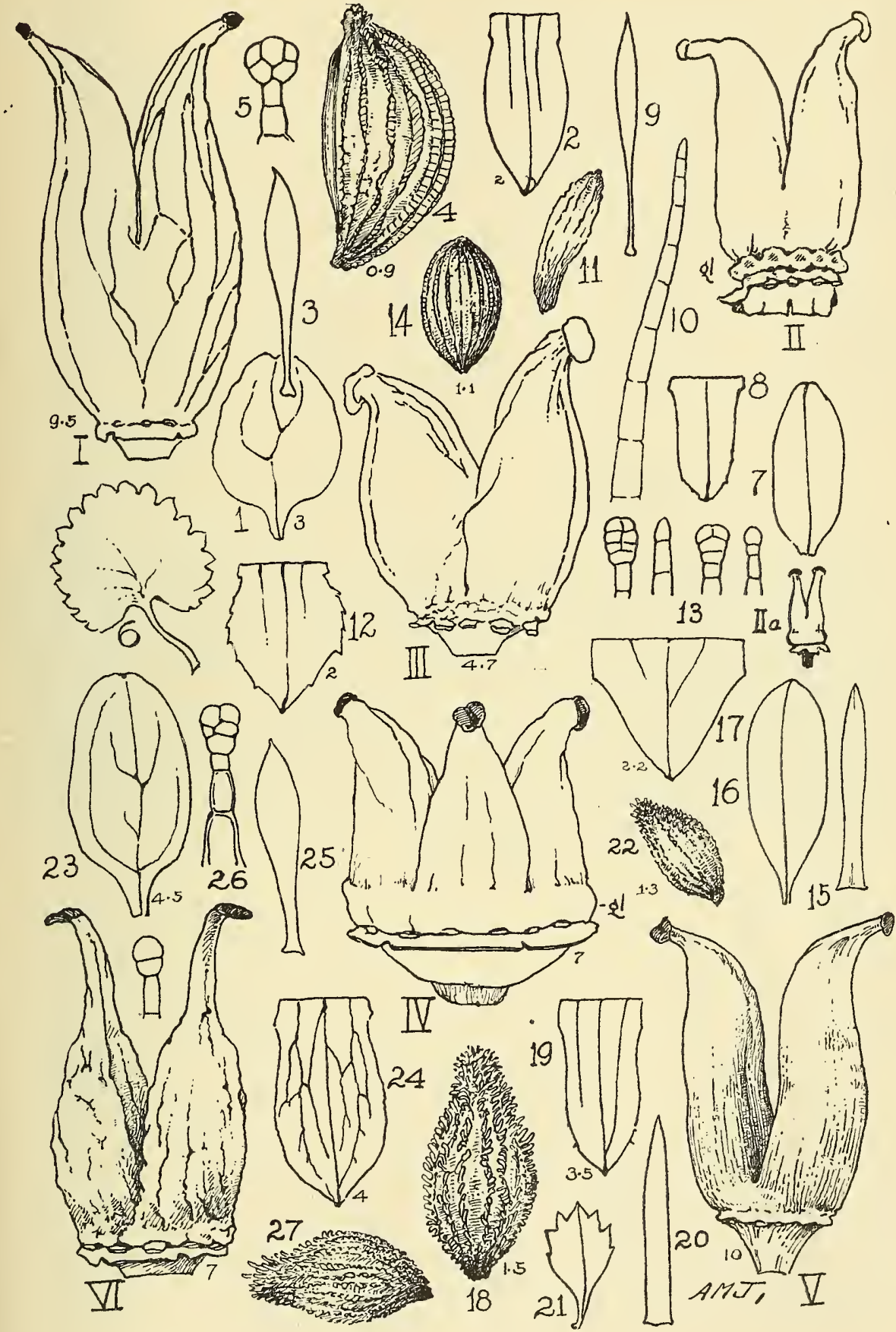

Plate IV 


\section{Plate V}

Section Calthophyllum. I, mature follicles of S. spicata; 1, petal; 2, sepals; 3, stamen and filaments; 4, leaf; 5 , hair; 6 , immature seeds; II, pistil, showing shape of the young carpel, with broad base; III, ventral side of young carpel, with adherent receptacle; I, drawn from a specimen collected by Dr. J. M. Coulter at Cape Vancouver (USNH 249391), the others drawn from a specimen collected by W. C. Mendenhall in the Valley of Alatna, Alaska (USNH 377352).

Section Aulaxis. IV. Flower of S. micranthidifolia; V, mature capsule; VI, immature carpels; VII, pistil with swollen gland at base; 7 , petals; 8 , sepals; 9 . stamen and filament; 10 , leaf; 11 , seeds; 12 , a seed much enlarged; 13 , hairs and their glands; drawn from Small and Heller's No. 246, from Grandfather Mountain (UMH). 


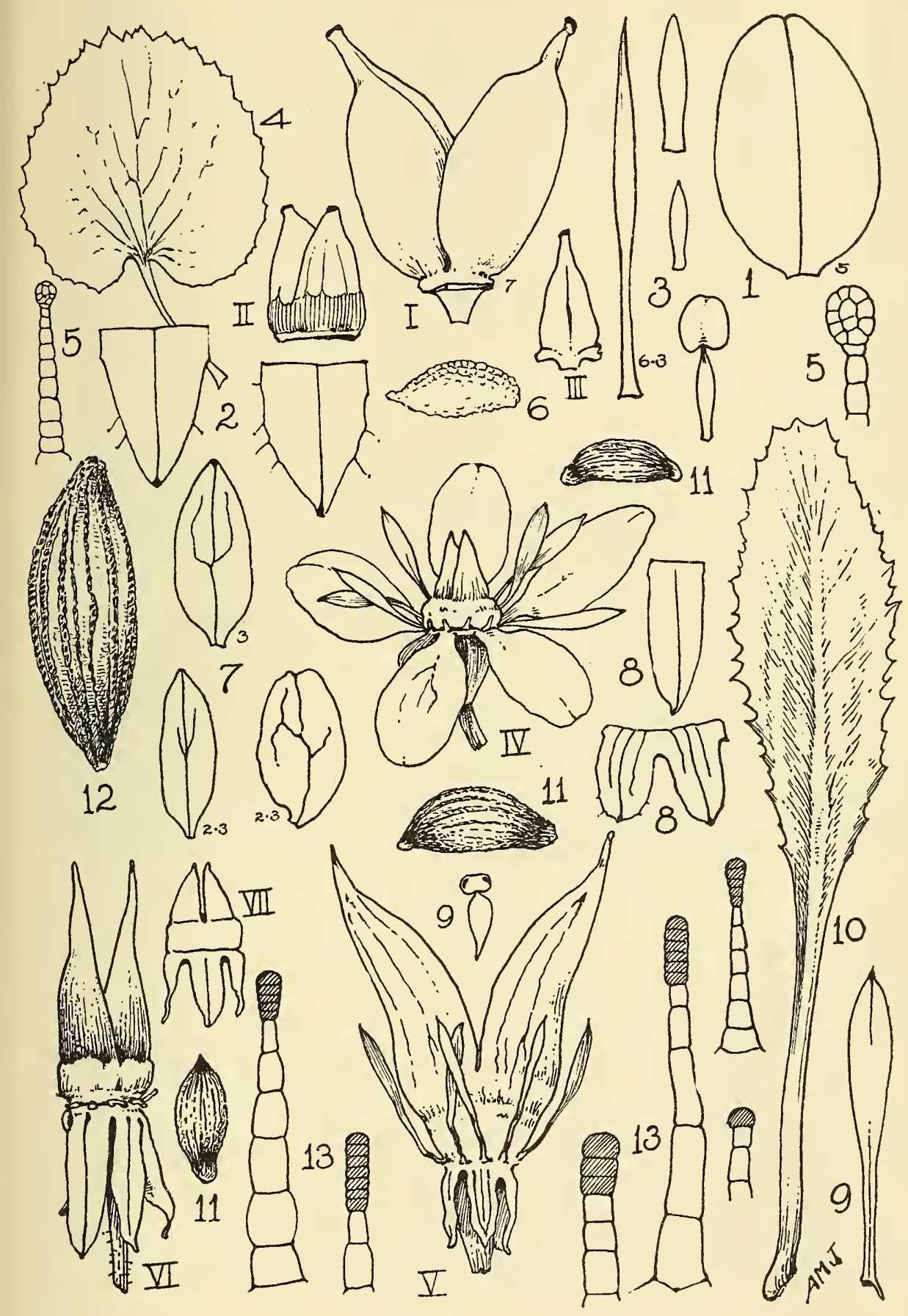

Plate V 


\section{Plate VI}

Section Dermasea. I, mature follicles of S. rufidula; II, lateral; III, ventral; IV, dorsal, views of a single follicle, the latter showing the shallow adherent receptacle; 1 , petals; 2 , sepals; 3 , filaments; 4 , seeds; 5 , a bract of the inflorescence; 6 , leaf; 7 , receptacle and calyx; drawn from Dr. C. O. Rosendahl's No. 1631, from Mount Arrowsmith, Vancouver Island, British Columbia (UMH).

V. Dorsal and ventral views of immature carpels of $S$. laevicaulis; 8 , petals; 9, sepals; 10, stamen and filament; 11, pistil of three carpels; drawn from C. V. Piper's No. 5061, from Mount Grayback, Oregon (UMH).

VI. Flower of S. aequidentata; VII, follicles; VIII, more mature follicles; 12 , petals; 13 , sepals; 14 , filament; 15 , receptacle and calyx; 16 , hairs : drawn from Suksdorf's No. 967, from Skamania County, Washington (UMH); IX and X, immature carpels, showing gland at base; XI, pistil of three carpels; XII, ventral side of young carpel showing depth of adherent receptacle; 17 , petals; 18 , sepals; 19 , filaments; 20 . seed; 21 , a bract of the inflorescence; 22 , leaves; 23 , gland of hair; drawn from a specimen collected by Thomas Howell at Oregon City (UMH). 
JOHNSON: A REVISION OF THE SECTION BORAPHILA
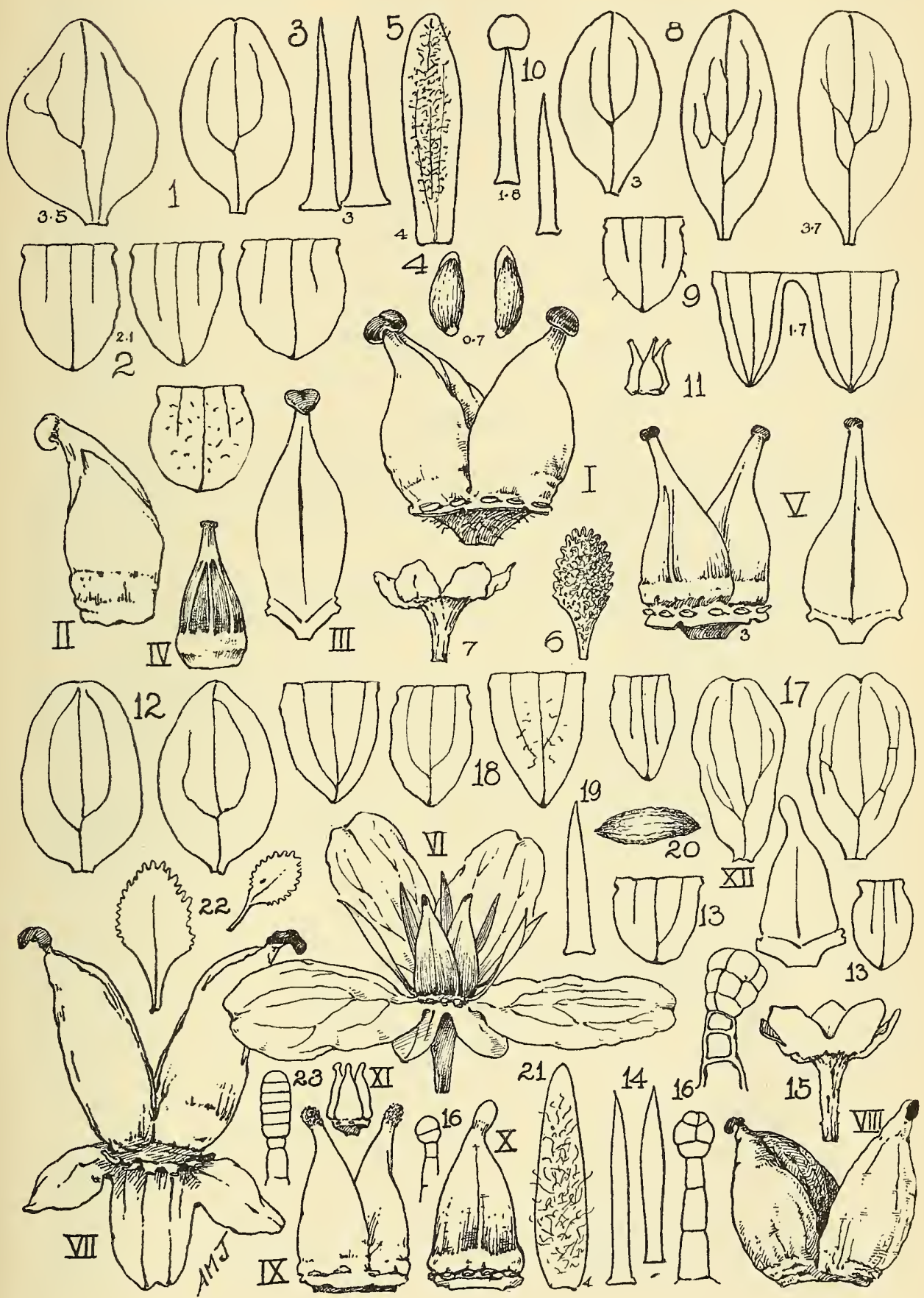

Plate VI 


\section{Plate VII}

I. Immature follicles of S. Allenii; II, dorsal and ventral views of a young carpel, showing gland and shallow receptacle; 1 , petals; 2 , sepals; 3 , stamen; 4 , bracts of the inflorescence; 5, gland of hair; drawn from H. D. Langille's No. 37, from Mount Hood, Oregon (USNH 525065).

III. Immature follicles of $S$. Marshallii; IV, young carpels showing gland at base, and dorsal rib; 6 , petals; 7 , sepals; 8 , stamens; 9 , hairs and their glands; drawn from Harley P. Chandler's No. 1613, from Marble Mountain, Siskiyou County, California (MBG 83016, UMH).

V. Follicles of S. Careyana; VI, ventral view of same; VII, dorsal and ventral view of young carpel showing gland and shallow receptacle; 10, petals; 11 , sepais; 12, filaments; 13, glands of hairs; drawn from John H. Redfield's No. 11721, from Roanoke Mountain, North Carolina (MBG 84285).

VIII. Follicles of S. tennesseensis; IX, dorsal side of an immature follicle showing region of the gland; 14 , petals: 15 , sepals; 16 , filament; 17 , seed; 18 , glands of hairs; drawn from a specimen collected by $A$. Ruth at Knoxville, Tennessee (MBG 84398). 


\section{Plate VIII}

I. A flower of S. caroliniana; II, mature follicles of same; III, immature follicles; IV, ventral side of a young carpel showing shallow adherent receptacle; V, early stage of the carpels; VI, ventral view of a mature follicle; 1 , petals; 2 , sepals; 3 , stamen; 4, leaf; 5 , seeds at left immature; 6 , glands of hairs; 7 , a bract of the inflorescence; $I$, drawn from a specimen in the Herbarium of the University of Minnesota; II and VI, drawn from a specimen collected by Dr. Asa Gray, C. S. Sargent, J. H. Redfield, and William M. Canby on Negro Mountain, North Carolina (MBG 84291), III, IV, and V from a specimen collected by J. D. Small at Chatham Hill Gap, Virginia (MBG 84288).

VII. Mature follicles of S. idahoensis; VIII, dorsal; IX, ventral sides of young carpels; X, a very young carpel showing gland; 8 , petals; 9 , sepals; 10 , stamen; 11 , leaves; 12, bract of inforescence; 13, glands of hairs; VII and 11 drawn from J. H. Sandberg's collection from the Palouse County, Washington, the others from Aiton's collection from Kootenai County, Idaho (UMH).

XII. Mature follicles of $S$. petiolata; XIII, ventral view of a mature follicle, showing the slightly adherent receptacle; 14 , petals; 15 , sepals; 16 , filament; 17 , seeds; 18 , a seed much enlarged; 19 , bract of inflorescence; 20 , glands of hairs; 21 , side view of mature fruit. 


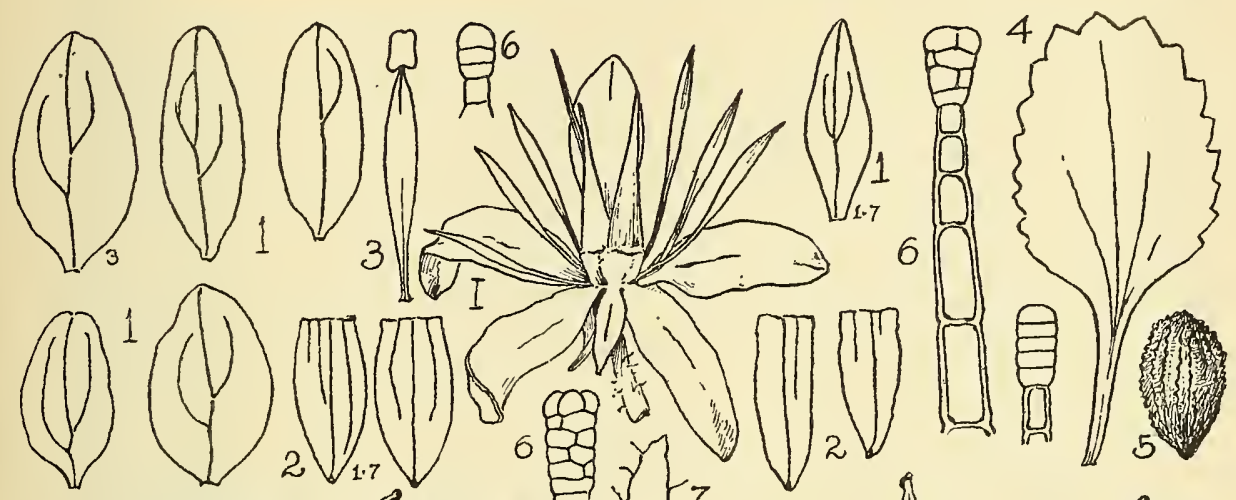
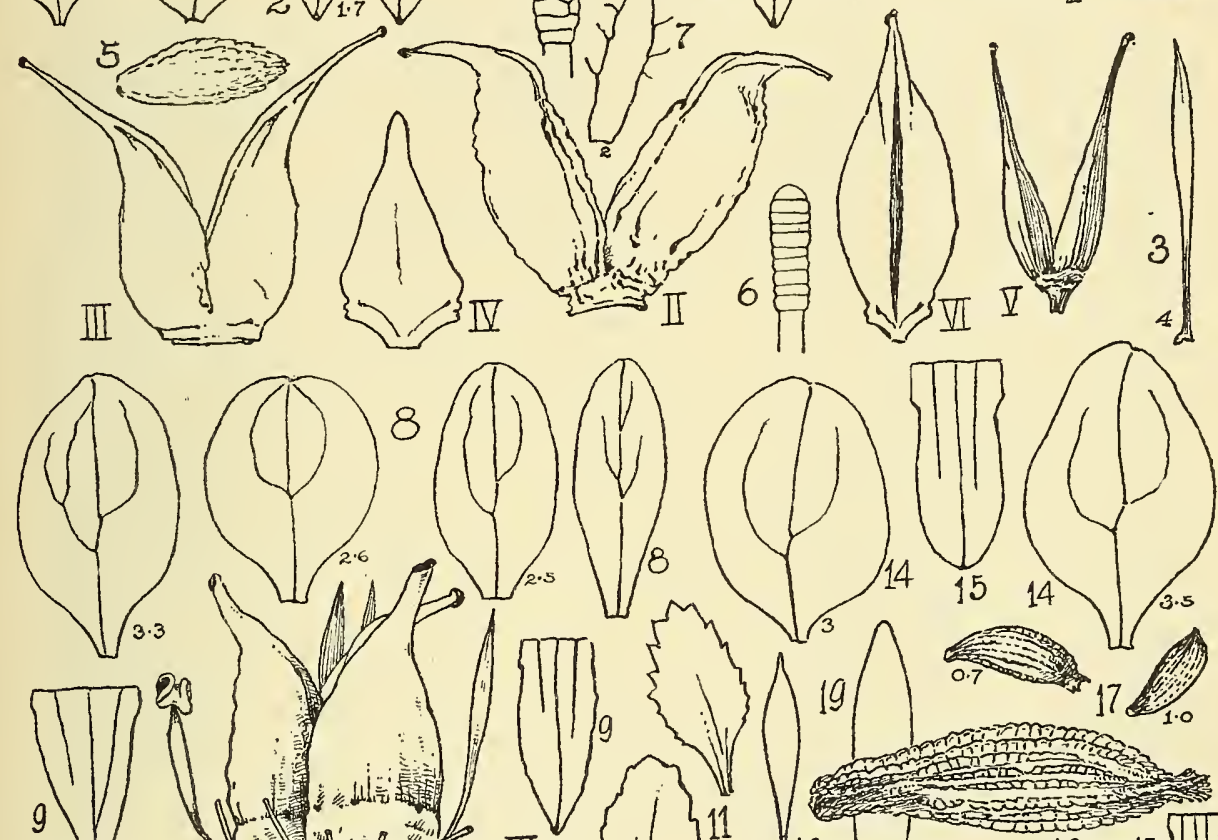

$9 \sqrt{ }(12,1)$

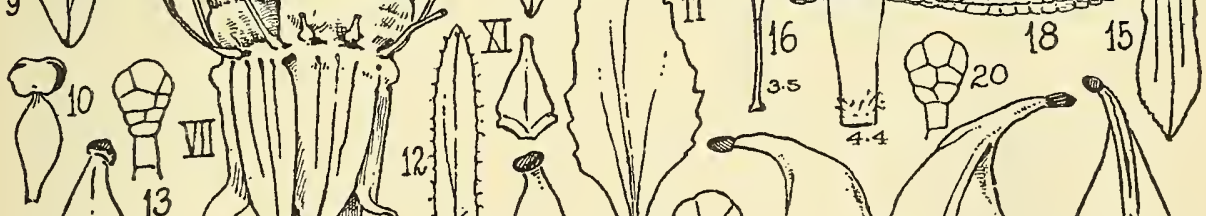

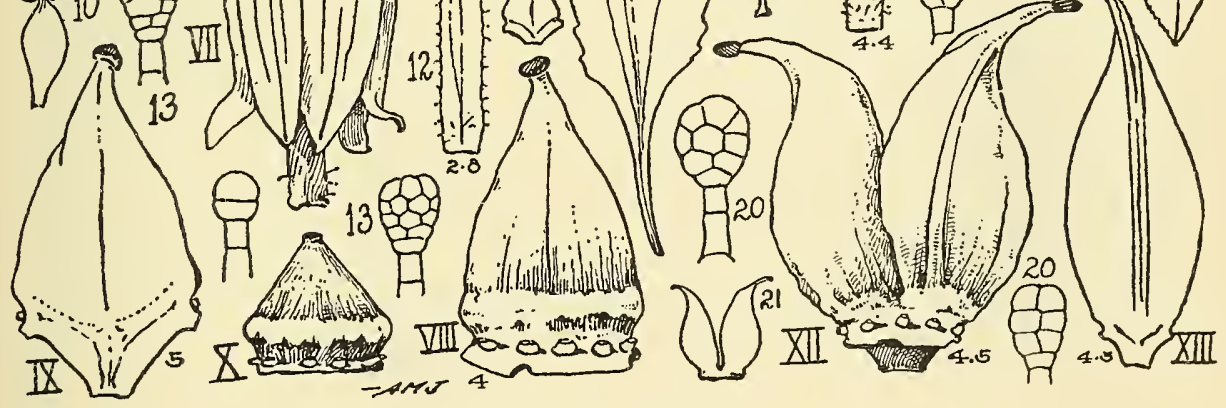

Plate VIII 


\section{Plate IX}

I. Follicles of S. Hallii; II, dorsal; III, ventral views of immature follicles; IV. ventral side of a young carpel; 1 , petals; 2 , sepals; 3 , stamen and a filament showing variation; 4, bracts of the inflorescence; 5 , glands of the hairs; drawn from Elihu Hall's No. 151, Oregon (MBG 84380).

V. Follicles of S. microcarpa; VI, dorsal; VII, ventral views of a single follicle; 6 , petals; 7 , sepals; 8 , stamen and a developed filament; 9 , bract of the inflorescence; 10, glands of the hairs; drawn from M. J. Elrod's No. 98, from Missoula, Montana, Herbarium of the University of Montana.

VIII. Immature follicles of S. klickitatensis; IX, ventral; $\mathrm{X}$, dorsal sides of a single follicle; 11 , petals; 12 , sepals; 13 , stamen; 14 , bract of inflorescence; 15 , hairs and their glands; drawn from a specimen collected by W. N. Suksdorf in West Klickitat County, Washington (USNH 45806).

XI. Flower of $S$. virginiensis, with parts cut away to show young carpels and gland; 16, stamens at different stages of development; drawn from J. H. Sandberg's collection from Two Harbors, Minnesota; 17, 18, and 19, various forms of petals found in different collections of S. virginiensis; 17, from Milford, Pennsylvania, C. A. Mill. collector (MBG 84374); XIV, XV, XVI, young carpels of same; 18, from Sandberg's collection from Two Harbors, Minnesota; 19, from Southington, Connecticut, C. H. Bissell, collector, No. 272 (and 813) (MBG 84364); 20, bracts of inforescence; 21, glands of hairs from different specimens; 22, seeds; XII, two carpels with the parts of flower cut away; XIII, ventral side of single carpel showing depth of the adherent receptacle; XII-XVI, and 22, drawn from Dr. J. M. Greenman's No. 629, from Stony Brook, Massachusetts (MBG 738779). 

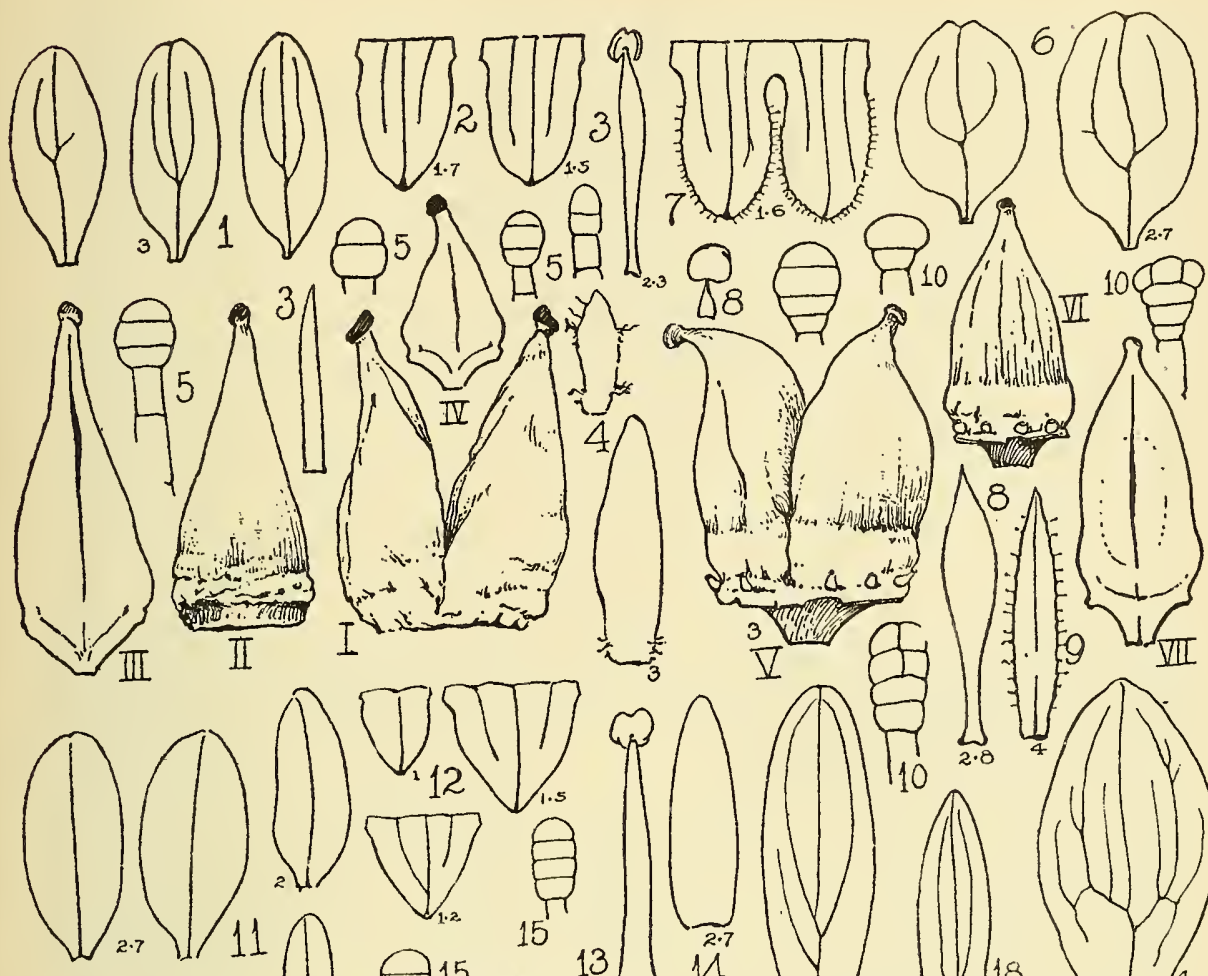

Q
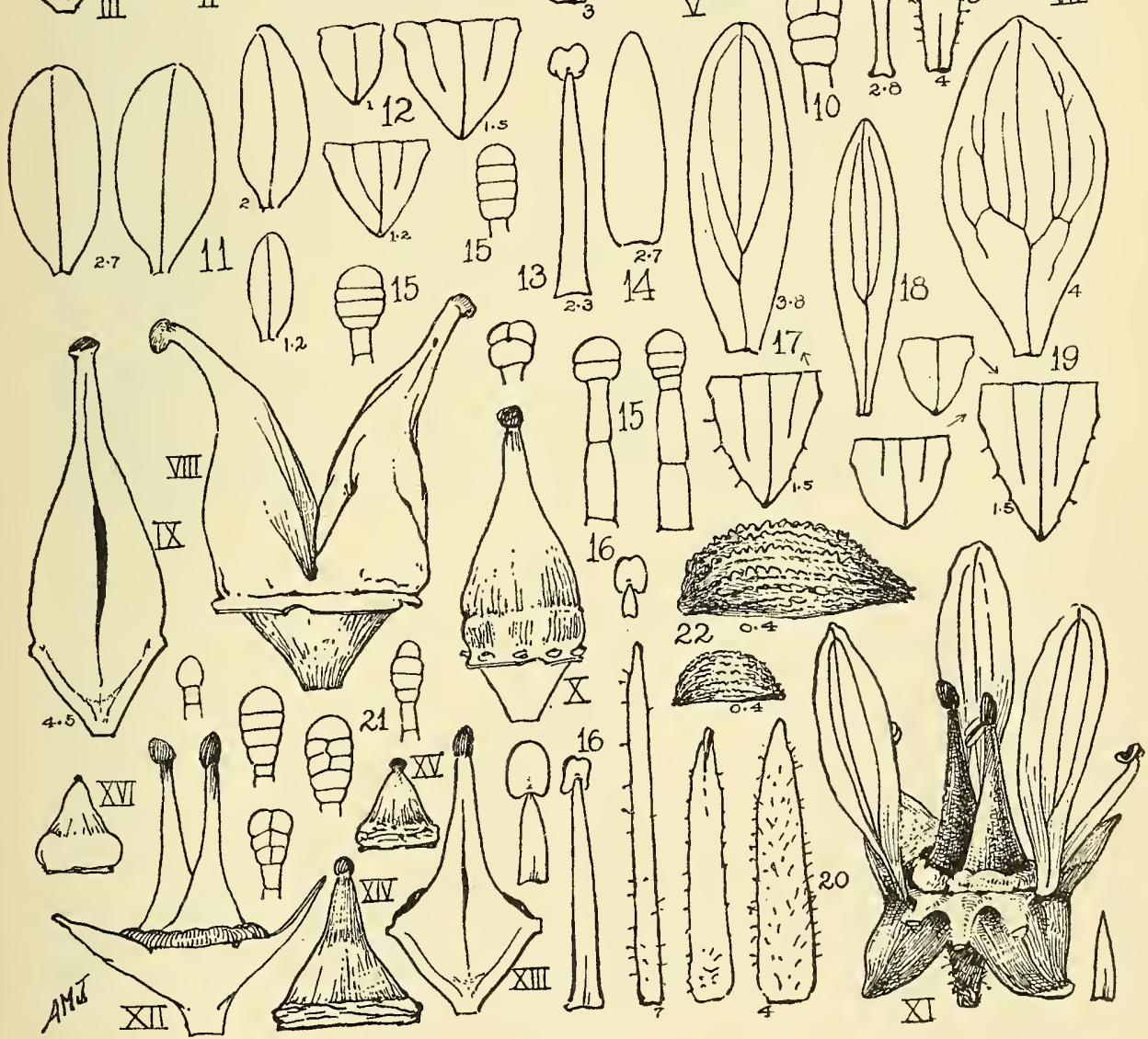

Plate IX 


\section{Plate X}

I. Follicles of $S$. nivalis, showing gland and deep adherent receptacle; II, young carpels; III, dorsal; IV, ventral sides of single carpel; 1 , petals; 2 , sepals; 3 , filaments; 4, seeds; 5 , glands of the hairs; drawn from Karl Hedbom's collection from the Dovre Fjeld, Norway (UMH).

V. Immature follicles of $S$. saximontana; VI, dorsal and ventral sides of a single carpel; VII, dorsal side of a young carpel; 7, petals; 8 , sepals; 9 , stamens; 10 , seeds (the lower much enlarged); 11, glands of the hairs; drawn from Sheldon's No. 8536, from the Wallowa Mountains, Oregon (USNH 528321); 12 , petals; 13, sepal; from a specimen collected by J. H. Sandberg in Kootenai County, Idaho (UMH) ; 14, stamen; 15, gland of hair; 16, bract of inflorescence; drawn from A. and E. Nelson's No. 5917, Yellowstone Park, Wyoming (UMH).

VIII. Follicles of $S$. occidentalis; drawn from a specimen collected by W. N. Cusick in the Powder River Mountains, Oregon (UMH); IX, ventral view of a mature carpel; $\mathrm{X}$ and XI, young carpels; 17 , petals; 18 , sepals; 19 , seeds; 20 , stamens ; 21, bracts of the inflorescence; 22, glands of the hairs; drawn from Elmer's No. 2646, from the Olympic Mountains, Clallam County, Washington (USNH 401969). 
JOHNSON: A REVISION OF THE SECTION BORAPHILA
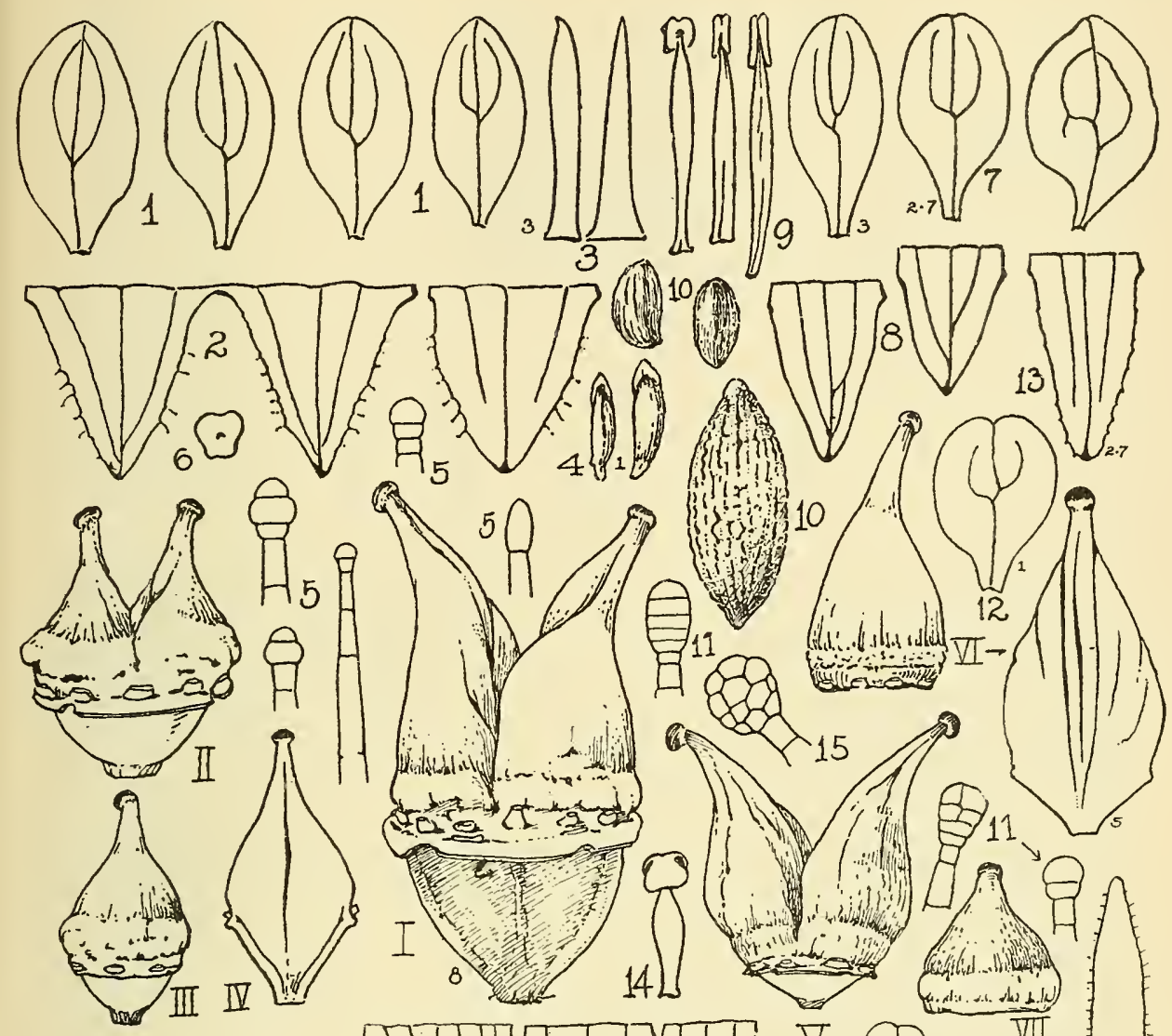

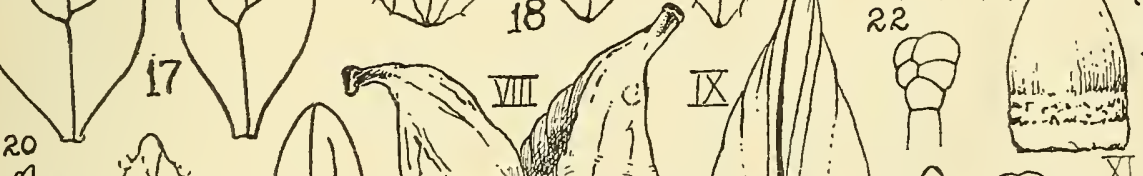

An 1 (

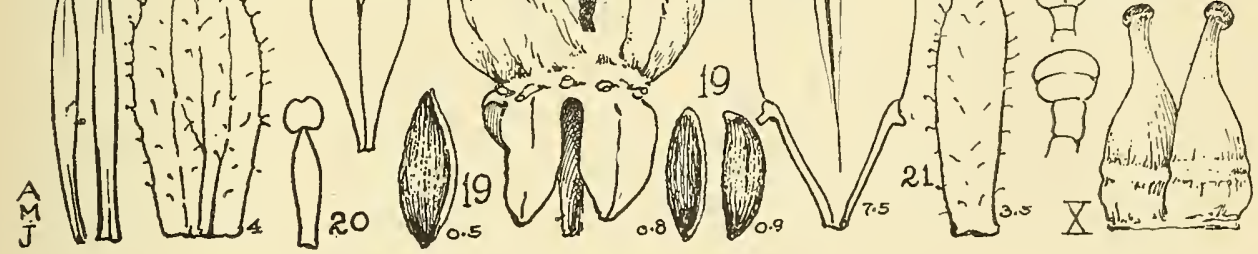

Plate X 


\section{Plate XI}

Section Chionophila. I, follicles of $S$. rhomboidea; II, ventral view of a follicle of same; 1 , petals; 2 , sepals; 3 , stamen; 4, hairs and their glands; 5 , bract of the inflorescence; drawn from J. W. Blankinship's No. 183, from Flathead Pass, Montana (MBG 84114); III, dorsal; IV, ventral views of carpels of another specimen of Blankinship's No. 183; 6, petals; 7, sepals; 8 , stamen; 9, hairs and their glands; from Blankinship's No. 183 (MBG 84114); 10, a type of gland commonly found on the hairs of $S$, rhomboidea.

V. A flower of S. hieracifolia; drawn from Dr. Wm. Trelease's No. 4035, from Hall Island, Alaska (MBG 83975); VI, follicles; VII, ventral view of a follicle; 11, petals; 12 , sepals; 13 , seeds ; 14, glands of hairs; drawn from Jas. M. Macoun's No. 55, from St. Matthew Island, Bering Sea (MBG 83978).

VIII. Follicles of $S$. franciscana; IX, ventral; $\mathrm{X}$, lateral views of a single follicle; 15 and 16, types of petals occurring in S. franciscana; 17, receptacle and calyx; 18, seed; 19, hairs and their glands; drawn from F. H. Knowlton's No. 127, from the San Francisco Mountains, Arizona (USNH 258261). 


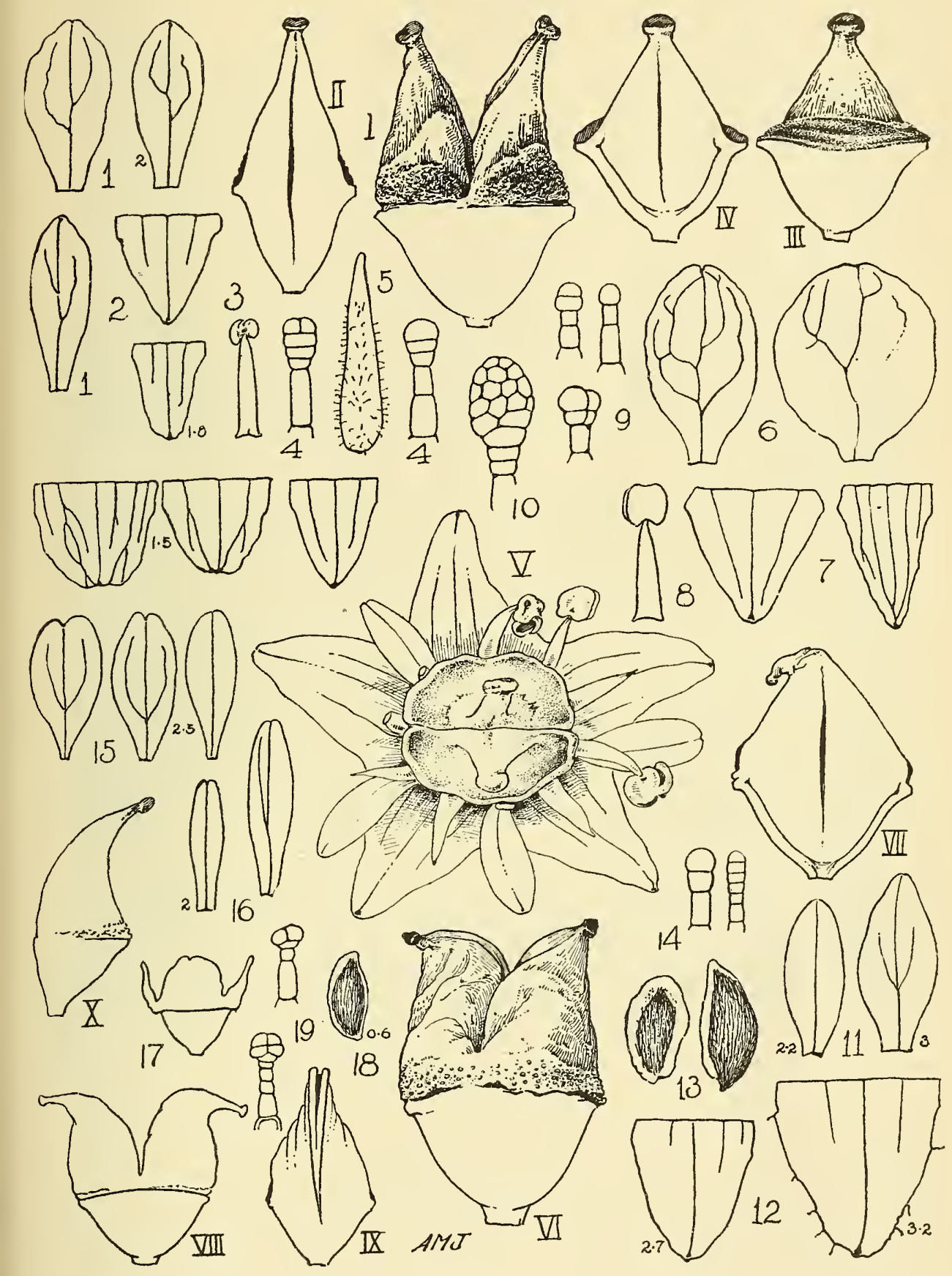

Plate XI 


\section{Piate XII}

Section Micranthes. I, follicles of S. Forbesii; 1, seeds; from MBG 84582; II and III, ventral views of mature follicles; II, from MBG 83820; III, from MBG 775263; IV and V, dorsal and lateral views of carpels; IV, from MBG 83859 ; V, from MBG 83862; VI, dorsal; VII, ventral views of young carpels; 2 , petals; 3 , sepals; 4 , stamen and filaments drawn from Vasey's specimen collected in Illinois, June, 1875 (MBG 84223) ; 5, seed; drawn from a specimen collected by Eggert near St. Louis, Missouri (MBG 84480).

VIII. Follicles of $S$. purpuripetala; 6 , petal; 7 , seeds of same; drawn from a specimen collected by Ferdinand Blanchard at Peacham, Vermont (MBG 751775); IX, dorsal view of a mature carpel of $S$. purpuripctala; 8 , two petals; 9 , speals; 10 , stamens; drawn from MBG 751771, Ferdinand Blanchard, Peacham, Vermont.

$\mathrm{X}$. Follicles of $S$. pennsylvanica; XI, ventral view of a mature follicle; XII, dorsal view of a young carpel; 12 , petals; 13 , sepals; 14 , a seed; drawn from a specimen collected by G. P. Ashcroft, Munson, Indiana (UMH) ; XIII, mature follicles; 15, a seed; drawn from a specimen collected by C. H. Bissell, No. 69, near Southington, Connecticut (MBG 84487); XIV, ventral view of an immature follicle; 16, a petal; drawn from a specimen collected by Thomas Morong near Cambridge, Massachusetts (MBG 84488) ; XV, ventral view of young carpel; 17 , three petals; 18 , a sepal; 19 and 20 , seeds from different specimens of S. pennsylvanica; 19 (MBG 84473), Redfield No. 2010 (MBG 84481); 21, common types of glands of hairs occurring in S. pennsyl. vanica.

XVI. Follicles of $S$. crassicarpa; XVII, dorsal view of a mature follicle (drawn on reduced scale) : 22, petal; 23, a sepal; 24, a filament; drawn from a specimen collected by H. Eggert in Wisconsin (MBG 83863); XVIII, XIX, dorsal views of two young carpels; XX, a more advanced carpel of same; 25 , a petal; 26 , a sepal; 27 , a stamen; 28, a bract of inflorescence; 29, gland of hair; drawn from a specimen collected by Virginius $H$. Chase near Wady Petra, Illinois (MBG 84469). 


\section{Plate XIII}

I. Follicles of S. zeinnebagoensis; II, ventral; III, dorsal views of a mature follicle; 1 , sepals; 2 , a filament; 3 , seeds; 4 , glands of hairs; drawn from W. A. Wheeler's No. 180, from the Winnebago Valley, Minnesota (UMH).

IV. A flower of $S$. oregana; V, follicles; VI, ventral view of a mature follicle; VII and VIII, very young carpels; 5 , petals; 6 , sepals; 7 , a stamen; 8 , seeds (drawn to different scales); 9 , bract of inflorescence; 10 , glands of hairs; drawn from Thomas Howell's No. 1498, from Lake Labish, Oregon (UMH).

IX. Follicles of S. Sierrae; X, dorsal; XI, ventral views of mature follicles; XII, young carpels showing gland; 11 , petals; 12 , sepals; 13 , filament; 14 , seeds; 15 , glands of hairs; drawn from Mrs. R. M. Austin's No. 83, from Colby, Butte County, California (UMH).

XIII. Advanced stage of pistil; XIV, ventral view of carpel; 16 , petals; 17 , a sepal; 18, glands of hairs; drawn from a specimen of Baker's type collection of $S$. arnoglossa, from Marshall Pass, Colorado (UMH); 19, a petal; 20, a sepal; from Baker's No. 4635; 21, two seeds; drawn from a specimen of $S$. arnoglossa; from Kenneth D. Mackenzie's No. 222, Colorado (MBG 83876). 


\section{Plate XIV}

I. Dorsal; II, ventral views of mature follicles of $S$. parvifolia; III, two young carpels of same, from above and side; 1 , petals; 2 , sepals; 3 , stamen and filaments; 4, glands of hairs; drawn from Thomas Howell's No. 1134, from Grant's Pass, Oregon (MBG 84381).

IV. Follicles of $S$. gracillima; V, ventral view of a mature follicle; VI, same of young carpel; VII, two young carpels, seen from above, showing gland; 6 , petals; 7 , sepals; 8 , bracts of inflorescence; 9, glands of hairs; drawn from A. A. Heller's No. 11214, from Butte County, California (MBG 745924).

VIII. Immature follicles of $S$. fallax; IX, ventral view of a follicle; $\mathbf{X}$, lateral view of same; 10 , petals; 11 , sepals; 12 , filament; 13 , seeds; 14 , seed enlarged; 15 , hairs and their glands; drawn from Marcus E. Jones' No. 3587, from Emigrant Gap, California (USNH 221361).

XI. A flower of S. californica; drawn from Pitt's No. 286, from Mount Tamalpais, California (UMH) ; XII, mature follicles; XIII, dorsal; XIV, ventral views of a carpel; 16, petal; 17, sepal; drawn from Baker's No. 370, from Santa Clara County. California (MBG 84275); 18 , petals; 19 , glands of hairs; drawn from Mrs. R. M. Austin's No. 859, California (MBG 84281) ; 20, stamens; 21, bracts of the inflorescence: 22 , diagram of a branchlet of the inflorescence; from $\mathrm{H}$. E. Brown's Na 150 , from Butte County, California; 23, a seed enlarged; 24, glands of hairs. 


\section{Plate XV}

S. nidifica: I and II, two flowers of the same collection of "S. plantaginea" Small; 1 and 3, petals and sepals of I; 2 and 4, the same of II; drawn from the type collection of Sandberg and Leiberg, from Spokane, Washington, May, 1893; 5, variations in petals of different flowers of the same plant; drawn from a specimen of a collection furnished by Mr. Alonzo P. Troth, of the Lewis and Clark High School, Spokane, Washington; III and IV, two different types of mature follicles in Piper's S. columbiana; V, dorsal view of a single follicle of III; 6 , two petals of same; 7 and 8 , mature and immature seeds; 9 , glands of hairs; VI, a flower showing both narrow and broad petals in the same flower (compare with I and II); drawn from Piper's No. 1808, from Pullman, Washington; VII, a flower of Suksdorf's S. bracteosa; VIII, dorsal; IX, ventral views of mature follicles of same (compare with III, IV, V) ; 10 , seeds; 11 , glands of hairs of same; drawn from Suksdorf's No. 1728, from the Columbia River, southwestern Washington (UMH); X, a flower of Suksdorf's No. 4014, S. bracteosa var. leptopetala, from West Klickitat County, Washington (UMH); XI, a young carpel from a flower of I, showing prominent verrucose gland. 
JOHNSON: A REVISION OF THE SECTION BORAPHILA 101

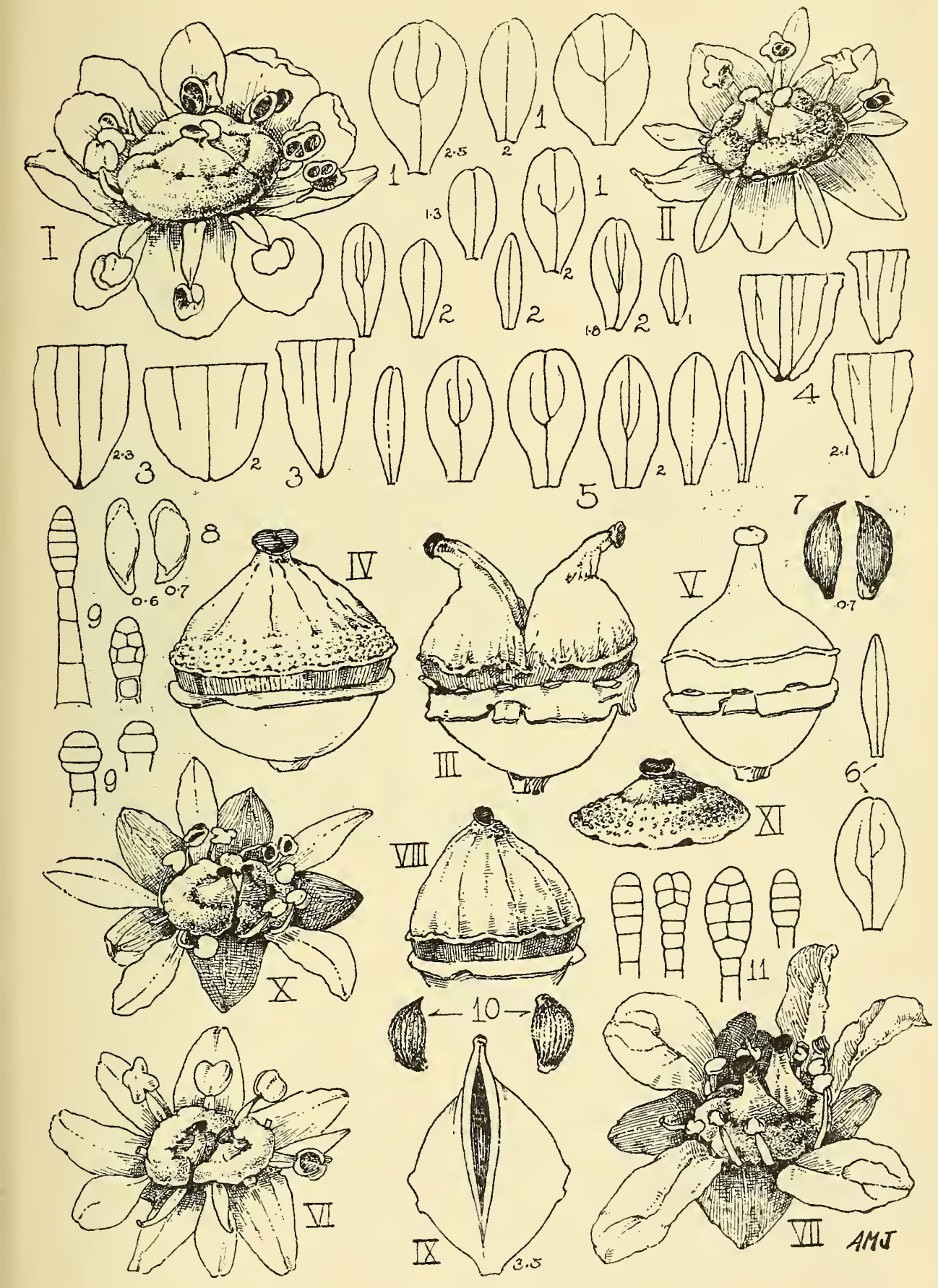

Plate XV 


\section{Plate XVI}

1. Pistil of S. montanensis; II, dorsal view of a young carpel; 1, a petal; 2, sepals; 3, a filament; 4, glands of hairs; $g$, gland of carpels; drawn from "E. C. S.'s" No. 155, from Electric Peak, Yellowstone National Park (USNH 488735); III, dorsal; IV, ventral views of a carpel; 5 , a petal; 6 , sepals; 7 , filaments; 8 , glands of hairs; $g$, gland of carpel; I, a pistil; drawn from another specimen of the same collection, (E. C. S. No. 155) ; V, dorsal; VI, ventral views of mature follicles; 9, petals ; 10, sepals; 11, a filament; 12, seeds; 13, glands of hairs; drawn from Rydberg and Bessey's No. 4264, from Spanish Basin, Gallatin County, Montana (USNH 360878).

VII. Dorsal view of a mature follicle of a specimen referred to $S$. integrifolia by Professor Joseph Marsh; VIII, a young carpel; IX, a more advanced stage of young carpel of same; 14, petals; 15 , sepals; 16, glands of hairs; drawn from Marsh's No. 85, University of Washington Herbarium; $\mathrm{X}$, dorso-lateral view of an immature follicle; XI, carpels at opening of flower; 17 , petals; 18 , sepals; 19 , stamen; 20 , glands of hairs; drawn from a specimen from Whidby Island, Washington, referred to $S$. integrifolia by N. L. Gardner, University of Washington Herbarium. 
JOHNSON: A REVISION OF THE SECTION BORAPHILA 103
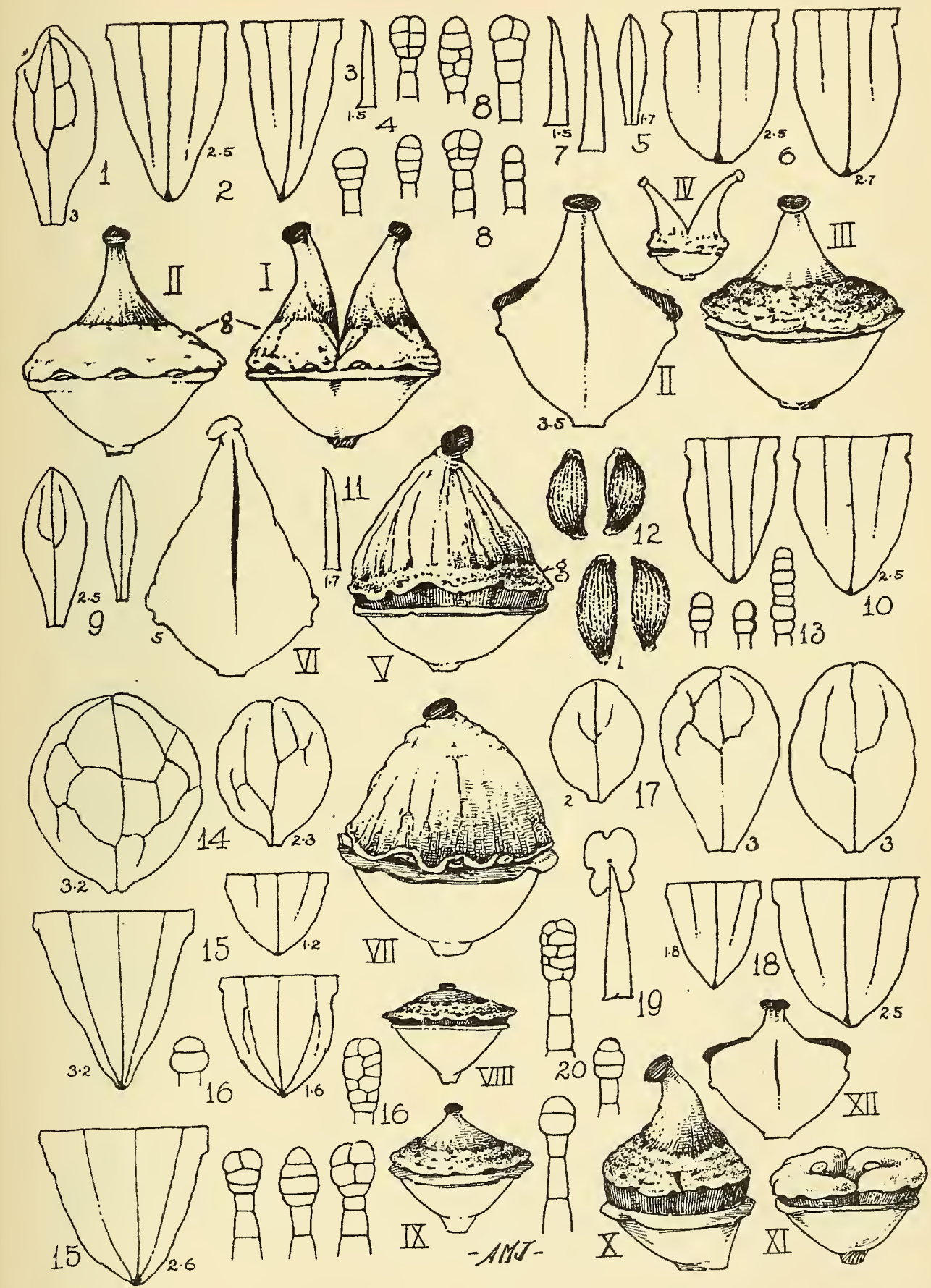

Plate XVI 


\section{Plate XVII}

I. A flower of S. fragosa; II, follicles; III, ventral; IV, dorsal views of immature follicles; $\mathrm{V}$, ventral views of a very young carpel, showing gland $g ; 1$, petals; 2, sepals; 3, filament; 4, seeds, the lowest much enlarged; 5 , glands of hairs; drawn from Suksdorf's No. 1427, from Klickitat County, Washington (UMH) ; VI, dorsal; VII, ventral views of mature follicles; 6 , petals; 7 , sepals; 8 , stamen; 9 , glands of hairs; drawn from Sheldon's No. 10109, from the Dalles, Oregon (UMH); VIII, lateral view of a mature; IX, dorsal view of an immature follicle; 10, a bract of the inflorescence; drawn from Elmer's No. 139, Almota, Whitman County, Washington (UMH).

$\mathrm{X}$. A flower of S. napensis; XI, young carpels; XII, dorsal view of an immature follicle; XIII, ventral view of sane; 11 , a filament; 12 , glands of the hairs; drawn from Hall and Chandler's No. 386, from the region of Dinky Creek, Fresno County. California (UMH).

XIV. Immature follicles of S. laevicarpa; XV, ventral; XVI, dorsal views of a follicle; 13, petals; 14 , sepals; 15 , glands of hairs; drawn from a specimen collected by William Moody at Friday Harbor, Washington, University of Washington Herbarium. 

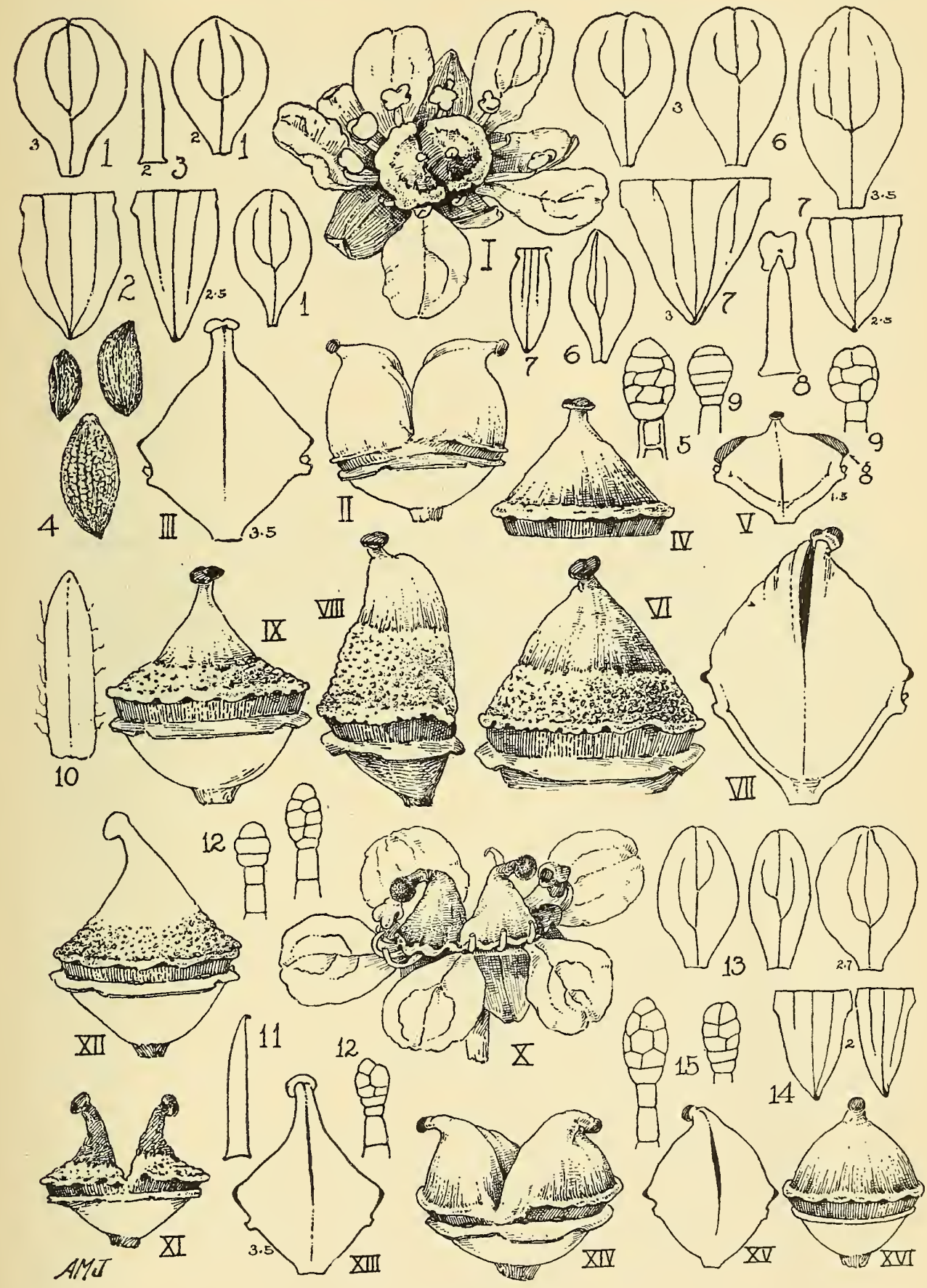

PI.ATE XVII 


\section{Prate XVIII}

Section Tricarpum. I, capsule of S. texana; II, dorsal view of an immature carpel of same; 1 , sepals ; 2 , petals ; 3 , stamen and filaments; 4 , seeds, hairs, and their glands; drawn from Ernest J. Palmer's No. 1647, from Reding's Mill, Newton County, Missouri (MBG 760519) ; III, capsule; 6, sepals; 7, immature seed; 8, bracts of inflorescence; 9, stigma enlarged; drawn from B. F. Bush's No. 5475, from Reding's Mill, Missouri (MBG 84597); IV, ventral view of an immature carpel; 10, sepal; 11, petals; 12 , seed; drawn from J. Reverchon's No. 3729, from Terrell-Elmo, Texas (MBG 84557); V and VI, ventral views of mature carpels; 13 , sepals; drawn from H. Ness' No. 1994, from Brazos County, Texas (MBG). 
JOHNSON: A REVISION OF THE SECTION BORAPHILA 107
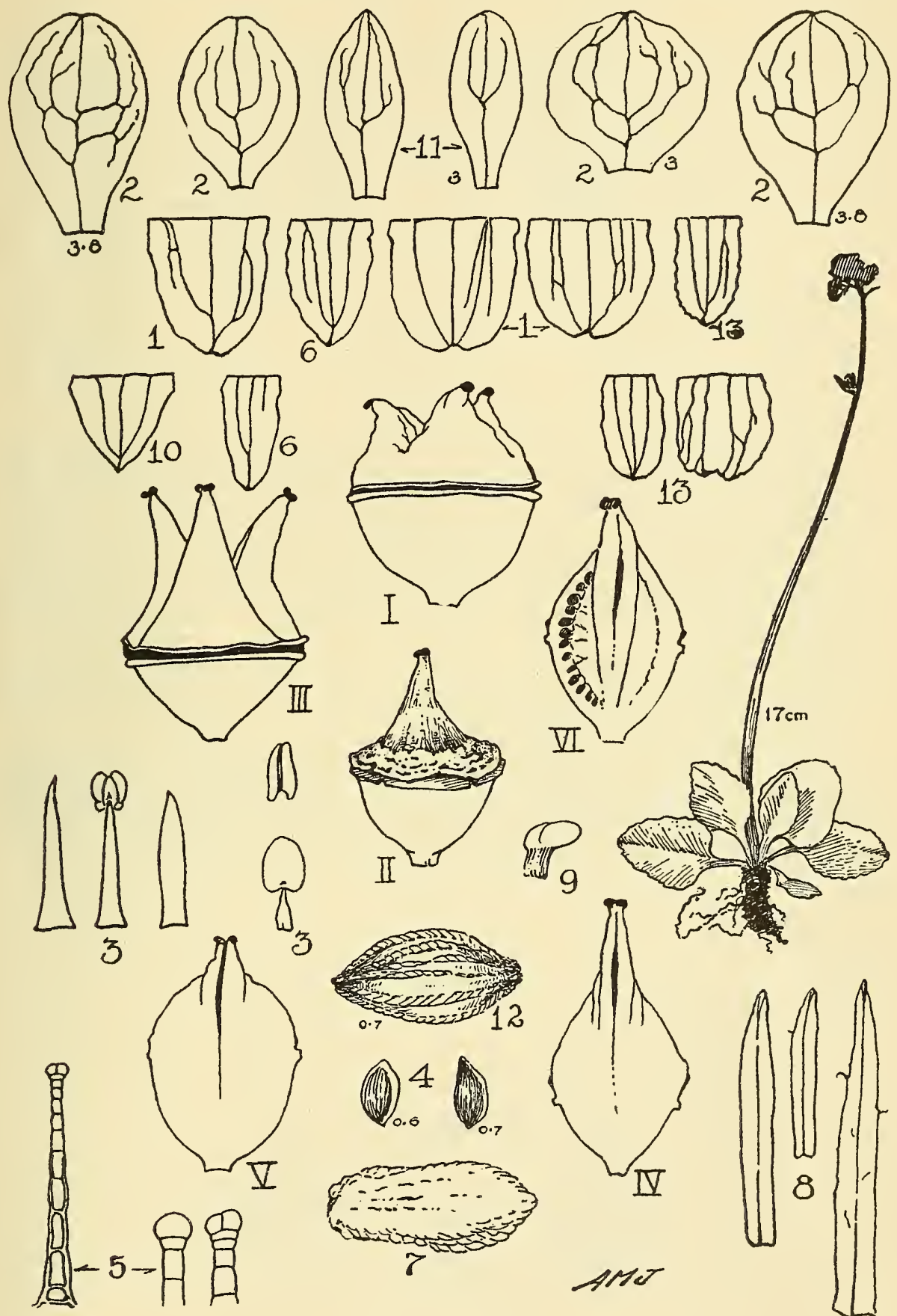

VI -

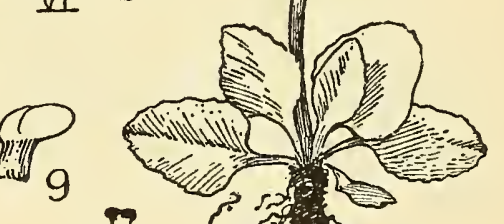

Plate XVIII 


\section{Plate XIX}

Section Arabisa. I, capsule of $S$. Leucanthemifolia; 1, petals; 2, sepals; 3, seed; 4, hair of same; drawn from specimen 1231b of the Biltmore Herbarium collection (UMH).

II. Capsule of S. ferruginea; 5, petals; 6, sepals of same; drawn from Dr. William Trelease's No. 4046, from Kodiak, Alaska (MBG 84045); 7, a stamen; 8, a seed; from Baker's No. 4921, collected by J. D. Culbertson at Windham Bay, Alaska (USNH 422334).

III. Pistil of S. bryophora; 9, filament; 10, petals; 11, sepals; drawn from Bolander's No. 5043, California; IV, capsule; drawn from Lemmon's No. 97 (MBG $84200)$; 12, bulbils of Saxifraga foliolosa.

Section Heterisia. V, a flower of S. Meretensiana; VI, advanced pistil; 13, a sepal; drawn from Thomas Howell's No. 1428, California (UMH); 14, a filament; 15, petals; 16 , a sepal; 17 , a cluster of bulbils; 18, a pair of bulbils of S. Mertensiana; drawn from Elmer's No. 2645, from the Olympic Mountains, Washington (UMH); VII, capsule of S. Mertensiana; 19, type of hairs in the section Heterisia 
JOHNSON: A REVISION OF THE SECTION BORAPHILA 109
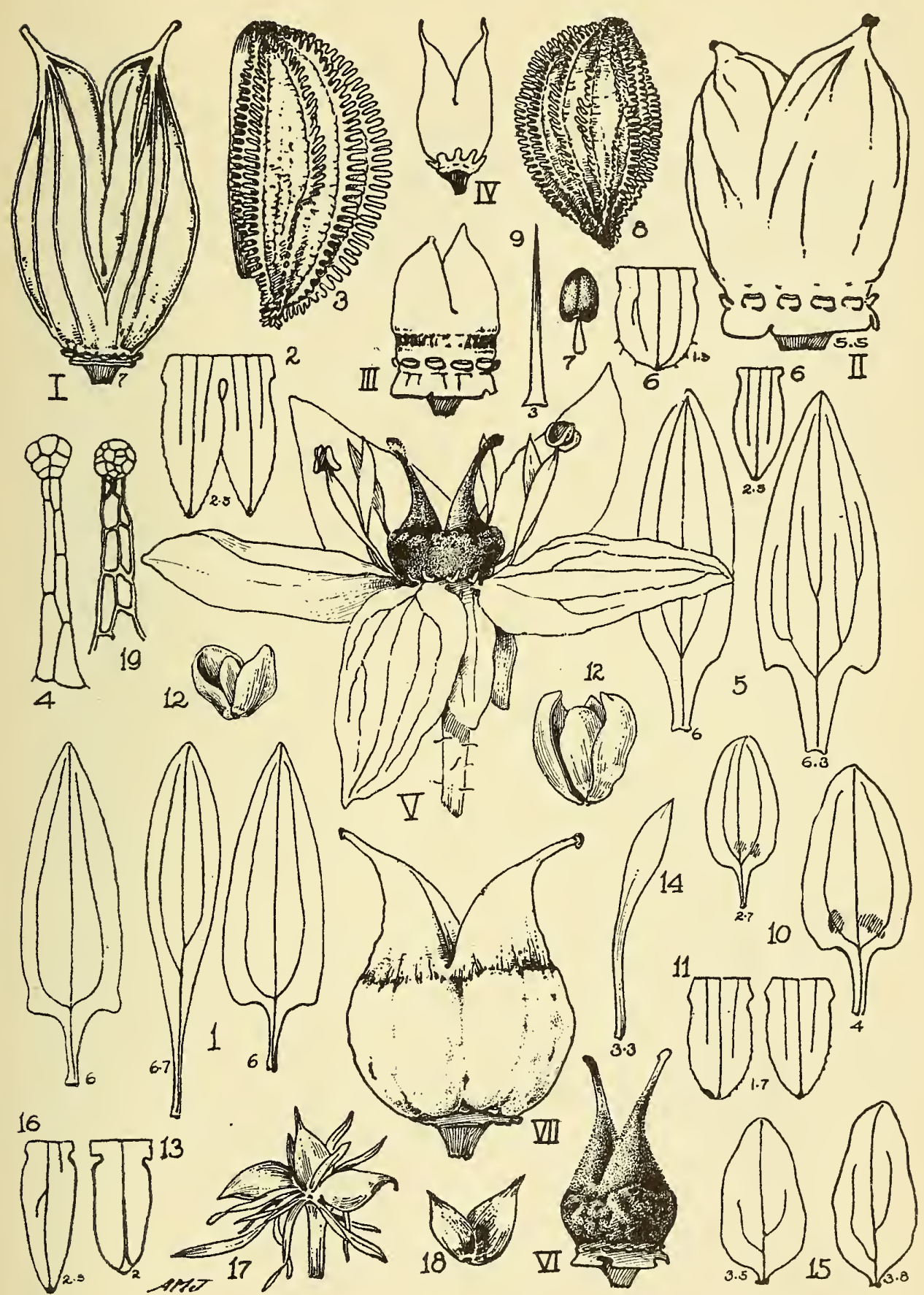

Plate XIX 


\section{VITA}

Arthur Monrad Johnson was born at Frederickstad, Norway, January 19, 1878, and emigrated to the United States with his mother and younge: brother in 1882, having been preceded by his father in 1880 . The family settled near Warren, Minnesota. He attended the common schools at Warren and later graduated from the state high school at Warren in June, 1897.

He taught in the elementary schools of Marshall County, Minnesota, for three years and then entered the University of Minnesota in 1900 . He graduated in June, 1904, with a Bachelor of Arts degree; pursued graduate work in botany at the Minnesota Seaside Station, Vancouver Island, in the summer of 1906; and in 1919 received the degree of Doctor of Philosophy from the University of Minnesota. He was an assistant in botany at the University of Minnesota during the summer session of 1902 ; assistant principal and instructor in science in the high school at St. Cloud, Minnesota, from 1904 to 1905 , and instructor in science in the high school at Colfax, Washington, from 1905 to 1909. During the summer sessions of 1908 and 1909 he was instructor in botany and geology in the Washington State College at Pullman, Washington; from 1909 to 1910 he was deputy county treasurer of Whitman County, Washington; from 1910 to 1916, instructor in biological science in the North Central High School, Spokane, Washington; instructor in botany, University of Washington during the summer session of 1913 ; instructor in botany during the summer quarters, De Pauw University, Greencastle, Indiana, in the summers of 1917 and 1919; from 1916 to 1919, teaching fellow in the University of Minnesota; from 1919 to the present, instructor in botany in that institution, and in the summer of 1921, he was appraiser for the Northern Pacific Railroad, Pacific Coast Division.

He has published the following: The Honey Bee and the Pollination of Ambrosia, American Botanist, 1917 ; The Use of the Text-Book in Beginning Classes in Botany, School Science and Mathematics, 1921 ; The Use of the Weed-Patch in Teaching High School Botany, School Science and Mathematics, 1923; Observations on the Carnivorous Propensities of the Gray Gopher, Journal of Mammology, 1922 ; Cryptomorpha, a New Section of the Genus Saxifraga, American Journal of Botany, May, 1923. 







\section{QL $136 . S 3$ J J 65}

Johnson Arthur Mon/A revision of the Nen

作

${ }_{3}$

3 5185000716108 


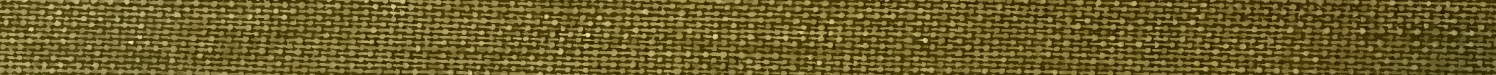
F,

trit?

s.

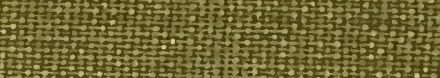
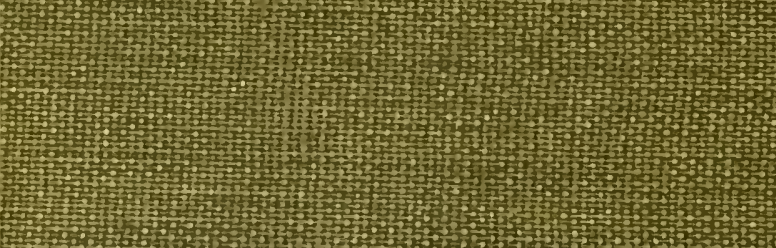
Tht

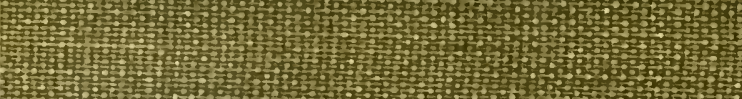

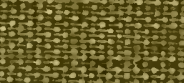

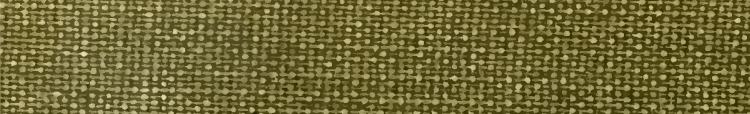

